UNIVERSIDADE DE BRASÍLIA

FACULDADE DE AGRONOMIA E MEDICINA VETERINÁRIA PROGRAMA DE PÓS-GRADUAÇÃO EM AGRONOMIA

TANQUES SÉPTICOS SEGUIDOS DE LEITOS CULTIVADOS COM DIFERENTES ESPÉCIES DE MACROFITAS NO TRATAMENTO DE ESGOTO

Ana Paula Reis

BRASÍLIA/DF

FEVEREIRO/2016 
UNIVERSIDADE DE BRASÍLIA

FACULDADE DE AGRONOMIA E MEDICINA VETERINÁRIA PROGRAMA DE PÓS-GRADUAÇÃO EM AGRONOMIA

TANQUES SÉPTICOS SEGUIDOS DE LEITOS CULTIVADOS COM DIFERENTES ESPÉCIES DE MACROFITAS NO TRATAMENTO DE ESGOTO

Ana Paula Reis

ORIENTADOR: PROF. DR. DELVIO SANDRI

DISSERTAÇÃO DE MESTRADO EM AGRONOMIA

PUBLICAÇÃO: 113/20016

BRASÍLIA/DF

FEVEREIRO/2016 
UNIVERSIDADE DE BRASÍLIA

FACULDADE DE AGRONOMIA E MEDICINA VETERINÁRIA PROGRAMA DE PÓS-GRADUAÇÃO EM AGRONOMIA

\title{
TANQUES SÉPTICOS SEGUIDOS DE LEITOS CULTIVADOS COM DIFERENTES ESPÉCIES DE MACROFITAS NO TRATAMENTO DE
} ESGOTO

\author{
Ana Paula Reis
}

DISSERTAÇÃO DE MESTRADO SUBMETIDO AO PROGRAMA DE PÓSGRADUAÇÃO EM AGRONOMIA, COMO PARTE DOS REQUISITOS NECESSÁRIOS À OBTENÇÃO DO GRAU DE MESTRE EM AGRONOMIA.

APROVADA POR:

DELVIO SANDRI, Doutor/FAV/UnB/ - Orientador

CICERO LOPES DA SILVA, Doutor/FAV/UnB/ - Examinador interno

MARCO ANTONIO ALMEIDA DE SOUZA, PhD/PTARH/FT/UnB/ Examinador externo

BRASÍLIA/DF

FEVEREIRO/2016 


\section{FICHA CATALOGRÁFICA}

Reis, Ana Paula

Tanques sépticos seguidos de leitos cultivados com diferentes espécies de macrofitas no tratamento de esgoto./ Ana Paula Reis, orientação de Delvio Sandri Brasília, 2016.

$79 \mathrm{p}$.

Dissertação de Mestrado(M) - Universidade de Brasília/ Faculdade de Agronomia e Medicina Veterinária, 2016.

CDD ou CDU

Agris / FAO

\section{REFERÊNCIA BIBLIOGRÁFICA}

REIS, A. P. Tanques sépticos seguidos de leitos cultivados com diferentes espécies de macrofitas no tratamento de esgoto. Brasília: Faculdade de Agronomia e Medicina Veterinária, Universidade de Brasília, 2016, 78 p. Dissertação de Mestrado.

\section{CESSÃO DE DIREITOS}

NOME DO AUTOR: Ana Paula Reis

TÍTULO DA DISSERTAÇÃO: Tanques sépticos seguidos de leitos cultivados com diferentes espécies de macrofitas no tratamento de esgoto.

GRAU: Mestre ANO: 2016

É concedida à Universidade de Brasília de Brasília permissão para reproduzir cópias desta dissertação de mestrado para única e exclusivamente propósitos acadêmicos e científicos. $\mathrm{O}$ autor reserva para si os outros direitos autorais, de publicação. Nenhuma parte desta dissertação de mestrado pode ser reproduzida sem a autorização por escrito do autor. Citações são estimuladas, desde que citada à fonte.

Nome: Ana Paula Reis

CPF: 01437298109

Endereço: SQS 316, Bloco D, Asa Sul, Brasília.

Tel.(061) 81539771 Email: anapaulareis.agro@gmail.com 
Dedico este trabalho primeiramente a Deus, por me acompanhar em todos os momentos da minha vida, pelas oportunidades e pelas pessoas maravilhosas que colocou em meu caminho. A minha família e amigos. 


\section{AGRADECIMENTOS}

A Deus, autor da minha fé, pelas pessoas maravilhosas que ele colocou no meu caminho durante essa jornada, pela vida e oportunidades que fizeram a diferença em minha vida.

Aos meus familiares, por serem meu porto seguro, minha fonte de sabedoria, minha alegria e meu equilíbrio. Agradeço por todo amor e paciência da minha mãe. E aos meus irmãos, pelo apoio.

Agradeço aos meus amigos e segunda família: Marco Antônio, Carmen, Juliana e Andrei, pela oportunidade de estudo que me proporcionaram, pelas palavras de incentivo, e que sempre estiveram ao meu lado e o apoio de sempre. Vocês foram essenciais, e devo tudo que sou a vocês.

Ao Professor Delvio Sandri, por todo esse tempo de orientação, por toda amizade, por sempre estar presente, pela paciência, pelo apoio e por todo crescimento profissional que me proporcionou.

Aos colegas de pesquisa que me acompanharam nesse projeto, pelo auxilio essencial nos trabalhos de campo, laboratório e pela amizade e valiosa ajuda.

A UnB e FAL-UnB e ao CNPq pela ajuda financeira no desenvolvimento do trabalho. A todos que contribuíram de alguma forma para a conclusão deste trabalho.

Muito obrigada! 


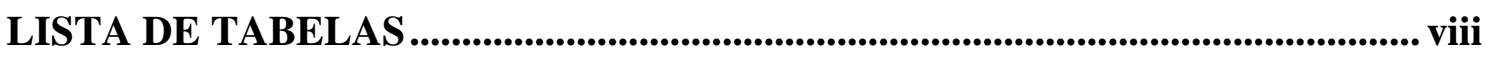

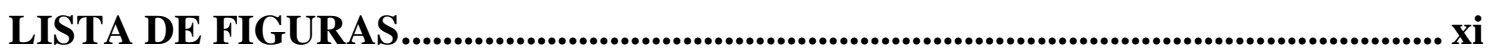

RESUMO

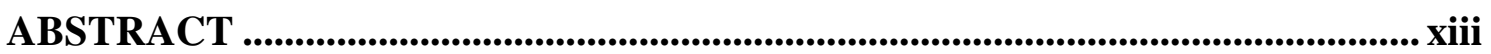

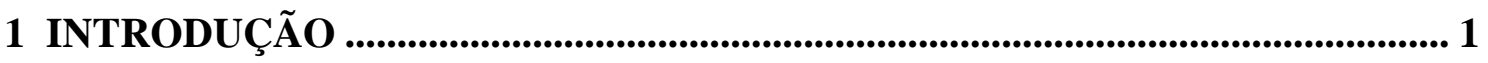

2 OBJETIVOS

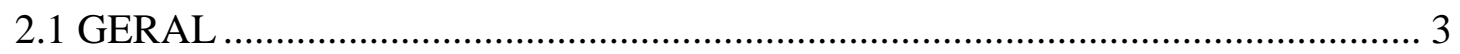

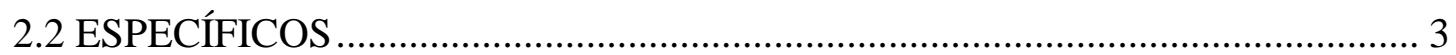

3. REVISÃO DE LITERATURA............................................................................ 3

3.1 CARACTERIZAÇÕES DOS ESGOTOS E LEGISLAÇÃO DE RECURSOS

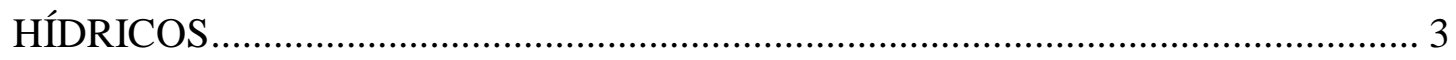

3.2 FUNDAMENTOS DO TRATAMENTO DE ESGOTO COM TANQUE

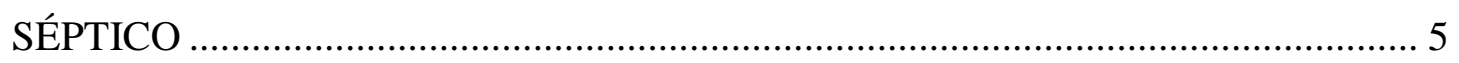

3.3 MECANISMOS NO TRATAMENTO DE ESGOTO COM LEITOS

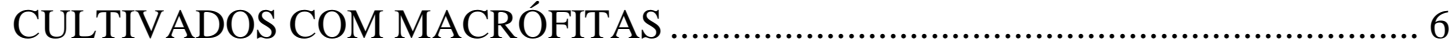

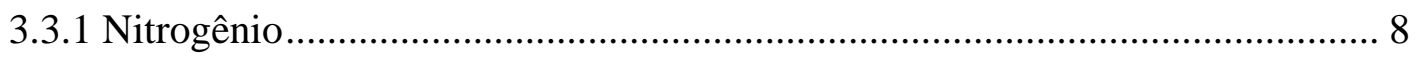

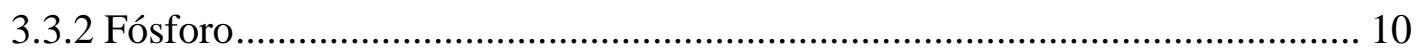

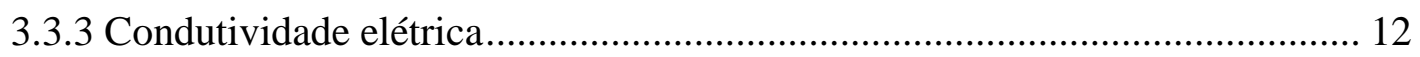

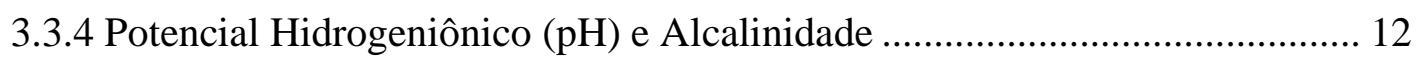

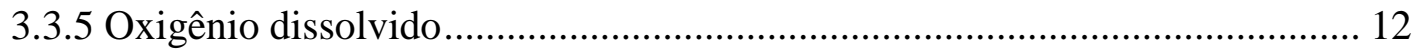

3.3.6 Demanda Bioquímica de Oxigênio .............................................................. 13

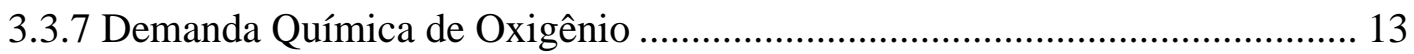

3.4. UTILIZAÇÃO DE MACRÓFITAS NO TRATAMENTO DE ESGOTO........... 14

3.5 MEIO DE SUPORTE DOS LEITOS CULTIVADOS ...................................... 16

3.6 EVAPOTRANSPIRAÇÃO DOS LEITOS COM MACRÓFITAS ...................... 17

4. MATERIAL E MÉTODOS ................................................................................... 18

4.1 CARACTERIZAÇÃO DO LOCAL DO EXPERIMENTO ................................. 18

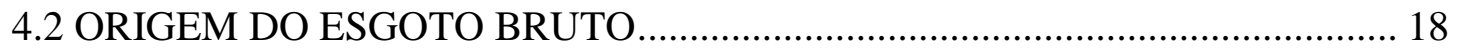

4.3 DESCRIÇÃO DA ESTAÇÃO DE TRATAMENTO DO EFLUENTE................. 19

4.3.1 Condução do esgoto e descrição geral da ETE/FAL/UnB ............................ 19

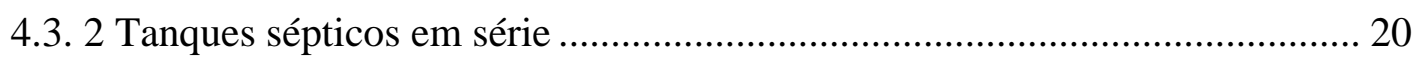

4.3.3 Caixa de passagem e leitos cultivados..................................................... 22 
4.4 COLETAS DAS AMOSTRAS DE EFLUENTE E PARÂMETROS

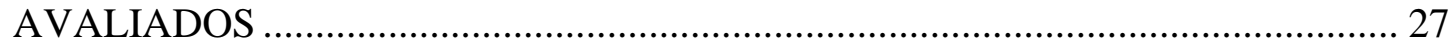

4.5 MANEJO DAS MACRÓFITAS NOS LEITOS DE CULTIVO ......................... 28

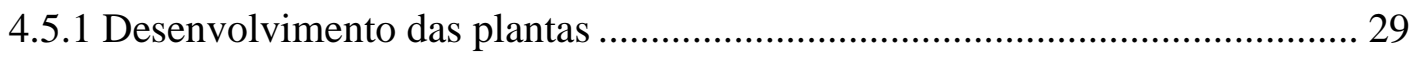

4.6 DETERMINAÇÕES DA EVAPOTRANSPIRAÇÃO POTENCIAL DOS

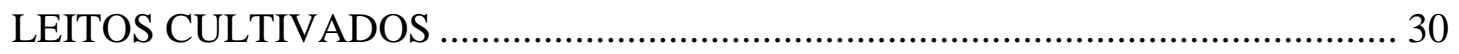

4.7 DADOS METEOROLÓGICOS DO PERÍODO DO EXPERIMENTO ................ 30

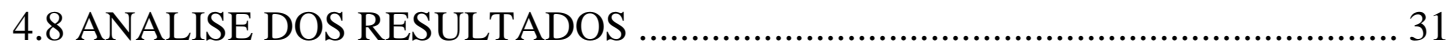

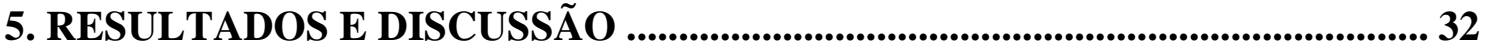

5.1 CARACTERIZAÇÃO DA VAZÃO E EVAPOTRANSPIRAÇÃO POTENCIAL

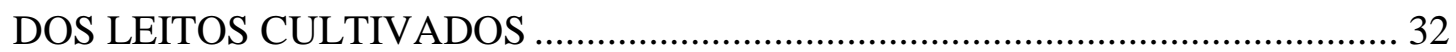

5.2 AVALIAÇÕES DOS PARÂMETROS FÍSICO-QUÍMICOS E

MICROBIOLÓGICOS DO EFLUENTE BRUTO, TANQUES SÉPTICOS (TS) E

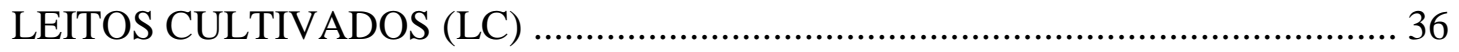

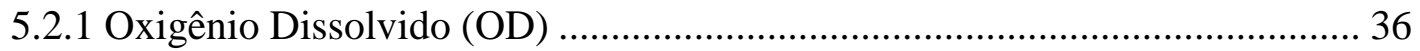

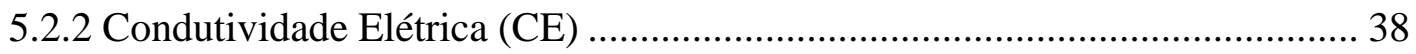

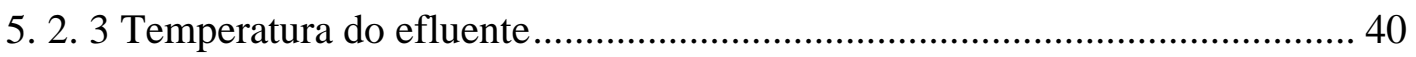

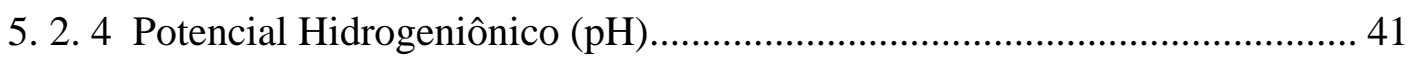

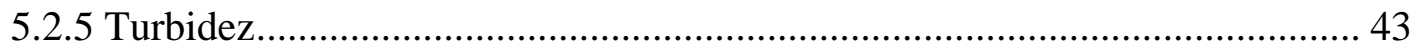

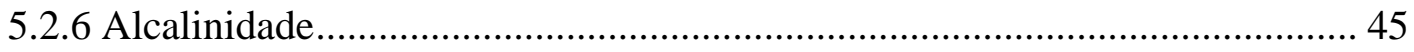

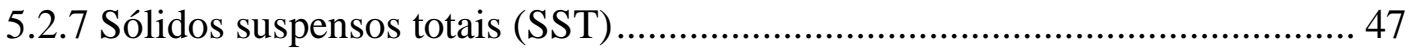

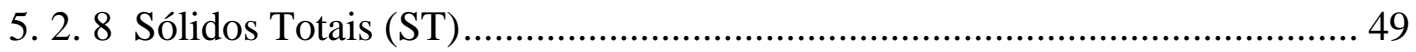

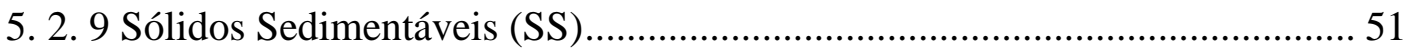

5. 2. 10 Demanda Química de Oxigênio (DQO) ................................................... 52

5. 2. 11 Demanda Bioquímica de Oxigênio (DBO) ................................................ 55

5. 2. 12 Nitrito $\left(\mathrm{NO}_{2}\right)$ e Nitrato $\left(\mathrm{NO}_{3}{ }^{-}\right)$e Amônia $\left(\mathrm{NH}^{4+}\right)$..................................... 56

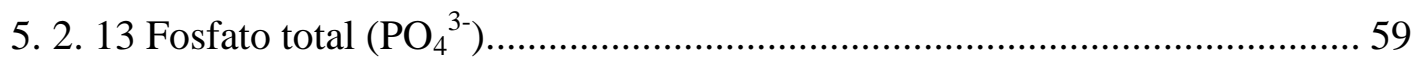

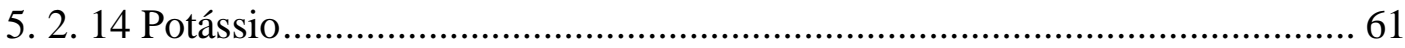

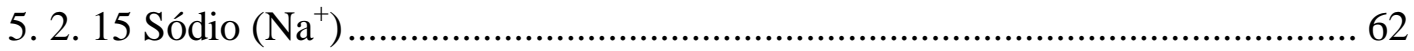

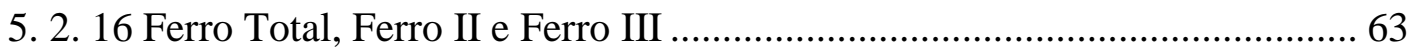

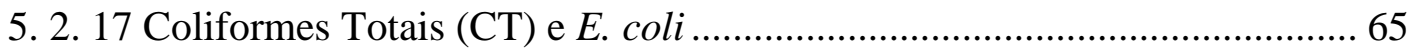

5.3 Adaptação e desenvolvimento das macrofitas ......................................................6 68

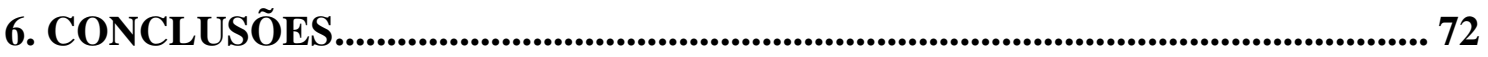

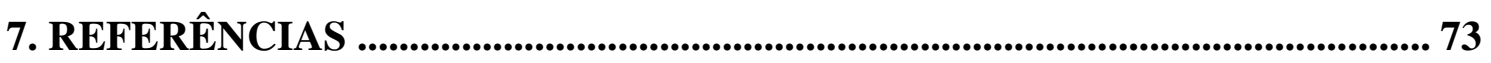




\section{LISTA DE TABELAS}

TABELA 1. Condições de lançamento de efluentes em corpos hídricos superficiais conforme Resolução do Conama n.430/2011.

TABELA 2. Critérios de projeto para os leitos cultivados de fluxo superficial (LCFS) e fluxo subsuperficial (LCFSS).

TABELA 3. Descrição dos pontos de coleta nos tanques sépticos em série (TS). ........ 21

TABELA 4. Descrição dos critérios de projeto e informações utilizadas no dimensionamento dos leitos cultivados da ETE/FAL/UnB para fluxo subsuperficial.

TABELA 5. Localização dos pontos de coleta do efluente para análise nos leitos

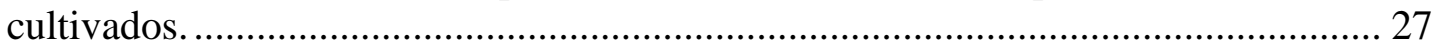

TABELA 6. Parâmetros analisados e seus respectivos métodos de análise para frequência de análise quinzenal. ........................................................................... 28

TABELA 7. Valores de precipitação, temperatura máxima, temperatura mínima e radiação solar nas datas de coleta em campo......................................................... 30

TABELA 8. Vazão de entrada nos leitos cultivados para período de medição das 8:00 às 18:00 h, critérios de projeto, parâmetros calculados nos leitos cultivados e TDH dos tanques sépticos, para as diferentes datas de coleta no ano de 2015 ........................ 34

TABELA 9. Vazão de entrada e na saída dos leitos cultivados no período da 8:00 às 18:00 h para diferentes datas do ano de 2015 para os leitos de cultivo.................... 35

TABELA 10. Valores médios diários de $\mathrm{OD}$, em mg.L $\mathrm{L}^{-1} \mathrm{O}_{2}$, desvio padrão, coeficiente de variação, teste de comparação de médias, considerando a entrada P1) e saída dos tanques sépticos (P2) e P2 em relação as saídas dos leitos cultivados (LC1, LC2, LC3 e LNC4) para diferentes datas de coleta .................................................................. 37

TABELA 11. Oxigênio Dissolvido em três horários de coleta para os diferentes pontos de coleta na ETE/FAL/UnB.

TABELA 12. Dados de Temperatura em ${ }^{\circ} \mathrm{C}$, desvio padrão, coeficiente de variação, teste de comparação de médias verificados entre a entrada e saída dos tanques sépticos (P1 e P2) e na entrada e saída dos leitos cultivados (P2 em relação a LC1, LC2, LC3 e LNC4). 40

TABELA 13. Dados de Temperatura em ${ }^{\circ} \mathrm{C}$, desvio padrão, coeficiente de variação, verificados entre o efluente bruto (P1) e saída dos tanques sépticos (P2) e entrada e saída dos leitos cultivados (LC1, LC2, LC3 e LNC4) para diferentes horários de coleta.

TABELA 14. Valores de $\mathrm{pH}$, desvio padrão, coeficiente de variação, teste de comparação de médias e eficiência total entre a entrada (P1) e saída dos tanques sépticos (P2) e entre a entrada (P2) e saída dos leitos cultivados (LC1, LC2, LC3 e LNC4) para diferentes datas de coleta.

TABELA 15. Valores de $\mathrm{pH}$, desvio padrão, coeficiente de variação, teste de comparação de médias entre o esgoto bruto $(\mathrm{P} 1)$ e saída dos tanques sépticos $(\mathrm{P} 2)$ e na entrada (P2) e saída dos leitos cultivados (LC1, LC2, LC3 e LNC4) para diferentes horários de coleta.

TABELA 16. Eficiência total diminuição na concentração de turbidez em NTU, desvio padrão, coeficiente de variação, teste de comparação de médias entre a entrada (P1) e saída dos tanques sépticos (P2) e entre a entrada (P2) e saída dos leitos cultivados (LC1, LC2, LC3 e LNC4) para diferentes datas de coleta.

TABELA 17. Valores de sólidos suspensos, em $\mathrm{mg} \mathrm{L}^{-1}$, desvio padrão, coeficiente de variação, teste de comparação de médias entre a entrada (P1) e saída dos tanques 
sépticos (P2) e entre a entrada (P2) e saída dos leitos cultivados (LC1, LC2, LC3 e LNC4), para diferentes datas de coleta.............................................................. 48

TABELA 18. Variação de sólidos totais na ETE (\%) entre a entrada (P1) e saída dos tanques sépticos (P2) e entre a entrada (P2) e saída dos leitos cultivados (LC1, LC2, LC3 e LNC4), para diferentes datas de coleta. 50

TABELA 19. Valores de sólidos sedimentáveis, em $\mathrm{mL} \mathrm{L}^{-1}$, desvio padrão, coeficiente de variação, teste de comparação de médias e eficiência total entre a entrada (P1) e saída dos tanques sépticos (P2) e entre a entrada (P2) e saída dos leitos cultivados (LC1, LC2, LC3 e LNC4), para diferentes datas de coleta.

TABELA 20. Valores de sólidos sedimentáveis, em $\mathrm{mL} \mathrm{L}^{-1}$, desvio padrão, coeficiente de variação, teste de comparação de médias e eficiência total entre a entrada (P1) e saída dos tanques sépticos $(\mathrm{P} 2)$, para diferentes horários de coleta. 52

TABELA 21. Valores de DQO, em $\mathrm{mg} \mathrm{L}^{-1}$ de $\mathrm{O}_{2}$, desvio padrão, coeficiente de variação, teste de comparação de médias e eficiência total entre a entrada (P1) e saída dos tanques sépticos (P2) e entre a entrada (P2) e saída dos leitos cultivados (LC1, LC2, LC3 e LNC4), para diferentes datas de coleta.

TABELA 22. Valores de DBO, em $\mathrm{mg} \mathrm{L}^{-1}$ de $\mathrm{O}_{2}$, desvio padrão, coeficiente de variação, teste de comparação de médias e eficiência total entre a entrada (P1) e saída dos tanques sépticos (P2) e entre a entrada (P2) e saída dos leitos cultivados (LC1, LC2, LC3 e LNC4), para diferentes datas de coleta. 55

TABELA 23. Valores de Nitrato, em $\mathrm{mg} \mathrm{L}^{-1}$, desvio padrão, coeficiente de variação, teste de comparação de médias e eficiência total entre a entrada (P1) e saída dos tanques sépticos (P2) e entre a entrada (P2) e saída dos leitos cultivados (LC1, LC2, LC3 e LNC4), para diferentes datas de coleta. 57

TABELA 24. Valores de Nitrito, em $\mathrm{mg} \mathrm{L}^{-1}$, desvio padrão, coeficiente de variação, teste de comparação de médias e eficiência total entre a entrada (P1) e saída dos tanques sépticos (P2) e entre a entrada (P2) e saída dos leitos cultivados (LC1, LC2, LC3 e LNC4), para diferentes datas de coleta. 58

TABELA 25. Valores de Amônia, em mg L ${ }^{-1}$, desvio padrão, coeficiente de variação, teste de comparação de médias e eficiência total entre a entrada (P1) e saída dos tanques sépticos (P2) e entre a entrada (P2) e saída dos leitos cultivados (LC1, LC2, LC3 e LNC4), para diferentes datas de coleta........................................................... 59

TABELA 26. Valores de Fosfato, em $\mathrm{mg} \mathrm{L}^{-1} \mathrm{PO}_{4}{ }^{3-}$, desvio padrão, coeficiente de variação, teste de comparação de médias e eficiência total entre a entrada (P1) e saída dos tanques sépticos (P2) e entre a entrada (P2) e saída dos leitos cultivados (LC1, LC2, LC3 e LNC4), para diferentes datas de coleta.

TABELA 27. Valores de potássio, em $\mathrm{mg} \mathrm{L}^{-1}$, desvio padrão, coeficiente de variação, teste de comparação das médias na entrada (P1) e saída dos tanques sépticos (P2) e entre a entrada (P2) e saída dos leitos cultivados (LC1, LC2, LC3 e LNC4), para diferentes datas de coleta.

TABELA 28. Valores de sódio, em mg L ${ }^{-1}$, desvio padrão, coeficiente de variação, teste de comparação de médias para os diferentes pontos e datas de coleta. 62

TABELA 29. Valores de ferro total, em $\mathrm{mg} \mathrm{L}^{-1}$, desvio padrão, coeficiente de variação, teste de comparação de médias e eficiência total entre a entrada (P1) e saída dos tanques sépticos (P2) e entre a entrada (P2) e saída dos leitos cultivados (LC1, LC2, LC3 e LNC4), para diferentes datas de coleta e diferentes datas do ano de $2015 \ldots . .63$

TABELA 30.Valores de ferro II, em $\mathrm{mg} \mathrm{L}^{-1}$, desvio padrão, coeficiente de variação, teste de comparação de médias e eficiência total entre a entrada (P1) e saída dos tanques sépticos (P2) e entre a entrada (P2) e saída dos leitos cultivados (LC1, LC2, LC3 e LNC4), para diferentes datas de coleta e diferentes datas do ano de 2015 .... 64 
TABELA 31. Valores de ferro III, em $\mathrm{mg} \mathrm{L}^{-1}$, desvio padrão, coeficiente de variação, teste de comparação de médias e eficiência total entre a entrada (P1) e saída dos tanques sépticos (P2) e entre a entrada (P2) e saída dos leitos cultivados (LC1, LC2, LC3 e LNC4), para diferentes datas de coleta, para diferentes datas do ano de 201565

TABELA 32. Valores de coliformes totais (CT), em NMP $100 \mathrm{~mL}^{-1}$, desvio padrão, coeficiente de variação, para diferentes datas do ano de 2015.

TABELA 33. Eficiência de remoção de coliformes totais (CT), desvio padrão, coeficiente de variação, médias no $\mathrm{P} 1$, tanques sépticos $(\mathrm{P} 2)$ e na saída dos leitos cultivados (LC1, LC2, LC3 e LNC4), para diferentes datas do ano de 2015 66

TABELA 34. Valores de E. coli, em NMP $100 \mathrm{~mL}^{-1}$, desvio padrão, coeficiente de variação, médias de Esgoto bruto (P1) tanques sépticos $(\mathrm{P} 2)$ e na saída dos leitos cultivados (LC1, LC2, LC3 e LNC4), para diferentes datas de análise do ano de 2015.

TABELA 35. Eficiência de remoção de E. coli desvio padrão, coeficiente de variação, médias no P1, tanques sépticos (P2) e na saída dos leitos cultivados (LC1, LC2, LC3 e LNC4), para diferentes datas do ano de 2015. 68 


\section{LISTA DE FIGURAS}

FIGURA 1. Localização de algumas dependências da FAL e planta baixa da estação de tratamento de esgoto (ETE/FAL/UnB).

FIGURA 2. Vista dos três tanques sépticos (TS1, TS2 e TS3) e indicação do sentido de escoamento do esgoto (a e b) e ponto de coleta de esgoto (c)................................. 21

FIGURA 3. Vista em corte dos três tanques sépticos instalados em série e pontos de coleta de esgoto para análise (P1 e P2) ................................................................ 22

FIGURA 4. Caixa de passagem para os leitos cultivados (a), vertedouros triangular no interior da caixa de passagem (b) vista dos leitos cultivados com plantas recém transplantadas e do leito não cultivado (c)............................................................ 22

FIGURA 5. Vista interna dos leitos antes do preenchimento com brita (a) e sistema de distribuição de água nos leitos cultivados (b)........................................................ 23

FIGURA 6. Vista dos cavaletes de controle do nível do efluente no interior dos leitos de cultivo e pontos de coleta dos leitos em campo ( $a, b$ e c) e em um "croqui" do sistema (d) mostrando o sentido do fluxo do efluente............................................... 24

FIGURA 7. Estacas de sustentação dos leitos cultivados no sentido do comprimento (a) e no sentido da largura (b).

FIGURA 8. Vista do leito cultivado com taboa (Leito 1), papiro-brasileiro (Leito 2), lírio do brejo (Leito 3) após o plantio e leito sem plantas (Leito 4), no transplantio. 29

FIGURA 9. Vista dos leitos cultivados: taboa (a), papiro - brasileiro (b), lírio do brejo (c), aos 120 dias após o transplantio..................................................................... 29

FIGURA 10. Valores de Condutividade Elétrica, em $\mu \mathrm{S} \mathrm{cm}^{-1}$ em diferentes datas de coleta para diferentes pontos avaliados na ETE. ..................................................... 39

FIGURA 11. Valores de Condutividade Elétrica, em $\mu \mathrm{S} \mathrm{cm}^{-1}$ em diferentes pontos de coletas em diferentes horários de coleta. ................................................................ 39

FIGURA 12. Valores médio de turbidez (NTU) para os P1, P2, LC1, LC2,LC3 e LNC4, entre o dia 20 de agosto á 07 de dezembro de 2015 ............................................. 44

FIGURA 13. Valores de Alcalinidade total, em mg L ${ }^{-1}$, entre o dia 20 de agosto á 07 de dezembro de 2015 para diferentes pontos de análises. ............................................. 47

FIGURA 14. Valores médio de sólidos Totais, em $\mathrm{mg} \mathrm{L}^{-1}$, analisadas entre datas: 20 de

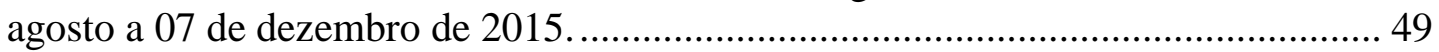

FIGURA 15. Leitos de cultivos no inicio do desenvolvimento vegetal - outubro/2015.69

FIGURA 16. Leitos de cultivos após 6 meses do tansplantio, janeiro/2016 .................. 69

FIGURA 17. Altura da Taboa (cm), entre outubro de 2015 e janeiro de 2016 .............. 70

FIGURA 18. Altura do Papiro - brasileiro (cm), entre outubro de 2015 e janeiro de

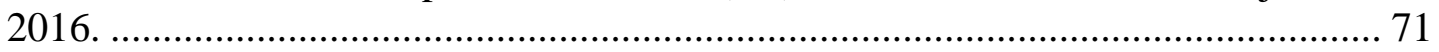

FIGURA 19. Altura do Lírio do brejo (cm), entre outubro de 2015 e janeiro de 2016. 71

FIGURA 20. Crescimento total das macrofitas nos bloco (cm) - 27 de Janeiro /2016; LC1 (Taboa), LC2 (Papiro-brasileiro) LC3 (lírio do brejo). ..................................... 72 


\section{RESUMO}

O presente trabalho teve como objetivo avaliar na fase inicial, o comportamento hidráulico e desempenho de tanques sépticos (TS) e leitos cultivados (LC) de fluxo subsuperficial, vegetados com as espécies aquáticas taboa (Typha spp) (LC 1), papirobrasileiro (Cyperus giganteus) (LC 2) e lírio do brejo (Hedychium coronarium Koehne) (LC 3) e um sem planta (LNC 4), construídos em paralelo e preenchidos com brita \# 2. A Estação de Tratamento de Esgoto (ETE) foi implantada na Fazenda Água Limpa (FAL) da Universidade de Brasília (UnB). Os TS foram constituídos de três caixas Policloreto de Vinila (PVC) de volume total de 5500 L cada, enquanto os LC foram construídos em estruturas retangulares de fibra de vidro, com espessura da parede de 4 $\mathrm{mm}$, apoiados sobre o solo, com dimensões de 2,5 m (largura), 6,5 m (comprimento) e 0,5 m (altura). O período de avaliação foi de agosto a dezembro de 2015, compreendendo a fase inicial de funcionamento da ETE/FAL/UnB. Foram realizadas oito campanhas de coleta de amostras, para quantificação de atributos físicos, químicos e microbiológicos do efluente bruto, após os tanques sépticos e dos leitos cultivos, totalizando seis pontos de coleta. Mediu-se o volume de efluente de entrada e saída dos leitos cultivados e o desenvolvimento das macrofitas. Os três tanques sépticos em série, apresentam maior influência na redução da turbidez $(12,4 \%)$, sólidos suspensos totais (28\%), nitrato $(15,7 \%)$, nitrito $(20 \%)$, amônia $(28,5 \%)$ e E. coli $(9 \%)$. A tendência da temperatura é de se manter estável $\left(30^{\circ} \mathrm{C}\right)$ nos TS e LCs, enquanto que o pH varia de 5,70 a 7,42 entre a entrada e saída dos TS. De modo geral, a tendência no LC com taboa é a de redução nas concentrações de sólidos suspensos totais $(58,6 \%)$ e sólidos totais (11,2\%), DBO (99,99\%), e com valores de sódio na saída do leito de $114,92 \mathrm{mg} \mathrm{L}^{-1}$, ferro II de $0,72 \mathrm{mg} \mathrm{L}^{-1}$ e condutividade elétrica de $908,78 \mu \mathrm{S} \mathrm{cm}^{-1}$; no LC com papirobrasileiro reduziu a DBO em 94,5\%, DQO em 60,5\%, e valores de ferro total na saída de $0,63 \mathrm{mg} \mathrm{L}^{-1}$, coliforme totais de $94.325 \mathrm{NMP} 100 \mathrm{~mL}^{-1}$ e potássio de $46,31 \mathrm{mg} \mathrm{L}^{-1}$; por sua vez, no LC com lírio do brejo reduziu a DQO em 71,6\%, DBO em 99,1\%, nitrato de $88,1 \%$ e nitrito de $83,6 \%$. A adaptação das espécies de macrófitas não é uniforme no interior dos leitos cultivados, com desenvolvimento aumentando da entrada em direção à saída dos mesmos.

PALAVRAS-CHAVE: zona de raízes, macrófitas, águas residuárias, tanque sépticos. 


\begin{abstract}
This study aimed at to evaluate the initial phase, the hydraulic behavior and the performance of septic tanks (TS) and wetlands (LC) subsurface flow vegetated with cattail aquatic species (Typha spp) (LC 1), papyrus-Brazilian (Cyperus giganteus) (LC 2) and lily fen (Hedychium coronarium Koehne) (LC 3) and without vegetation (LNC 4), built in parallel and filled with gravel \# 2. Sewage treatment plant (WWTP) was located at Fazenda Água Limpa (FAL) of the University of Brasília (UnB). TS were made of three Polyvinyl Chloride (PVC) boxes of of $5500 \mathrm{~L}$ each, while LC were built withinh rectangular structures of fiberglass, with a wall thickness of $4 \mathrm{~mm}$, resting over the soil surface and having the following dimensions: $2.5 \mathrm{~m}$ (wide), $6.5 \mathrm{~m}$ (length) and $0.5 \mathrm{~m}$ (height). The evaluation period was comprehended from August to December 2015, including the initial phase of operation of ETE/FAL/UnB. Eight sampling campaigns were carried out in order to quantify physical, chemical and microbiological attributes of the raw effluent, and after passing through the septic tanks and crop beds, totaling six points of collection. The characteristics measured were the effluent volume in the entrance and in the exit of the devices and the development of aquatic plants naturally growing. The three septic tank arranged in series (in parallel?), have the greatest influence on the reduction of turbidity (12.4\%), total suspended solids (28\%), nitrate (15.7\%), nitrite (20\%), ammonia (28.5\%) and E. coli (9\%). Temperature tended to remain stable $\left(30^{\circ} \mathrm{C}\right)$ in the LC'S and the TS, while the $\mathrm{pH}$ ranges from 5.70 to 7.42 across entrance and exit of TS. In general, LC cultivated with cattail reduced the total suspended solids concentration (58.6\%) and the total solids (11.2\%), BOD (99.99\%), presenting the following values for sodium, iron and electrical conductivity in the exit of the device: $114.92 \mathrm{mg} \mathrm{L}^{-1}, 0.72 \mathrm{mg} \mathrm{L}^{-1}$, and $908.78 \mu \mathrm{S} \mathrm{cm}^{-1}$, respectively; LC papyrus-Brazilian reduced BOD in $94.5 \%, \mathrm{COD}$ in $60.5 \%$ and presented the following values for total iron, total coliform and Potassium at the exit of the device: $0.63 \mathrm{mg} \mathrm{L}^{-1}$, 94.325 NMP $100 \mathrm{~mL}^{-1}$, and 46,31 $\mathrm{mg} \mathrm{L}^{-1}$, respectively; the LC swamp lily, for instance, reduced COD in $71.6 \%$, BOD in $99.1 \%$ nitrate in $88.1 \%$ and nitrite in $83.6 \%$. The adaptation of macrophytes is not uniform within the wetlands, with development increasing from the entrance toward the exit thereof.
\end{abstract}

KEYWORDS: root zone, macrophytes, wastewater, septic tank. 


\section{INTRODUÇÃO}

O lançamento de esgotos sanitários e industriais está entre os principais responsáveis pelos impactos negativos à água no Brasil. Como consequência, diferentes problemas ambientais têm sido relatados, incluindo consequências danosas à saúde da população humana (TUNDISI, 2005). Ao mesmo tempo, a qualidade da água existente na natureza vem diminuindo gradativamente em muitos locais, como consequência do intenso uso agrícola e nas indústrias, dentre outros setores da sociedade (REBOUÇAS, 2010).

Neste sentido, é fundamental o tratamento adequado do esgoto gerado em diversos setores da economia. Dentre as técnicas de tratamento disponíveis, especialmente para pequenos e médios volumes de esgoto gerado, o uso de tanques sépticos seguidos de leitos cultivados apresenta-se como alternativa promissora.

No Brasil e em outros países, nos últimos anos, muitas pesquisas foram desenvolvidas com o uso de leitos cultivados ou wetlands construídas (SANTOS et al., 2011; COLARES e SANDRI, 2013), tendo como principais vantagens, o baixo custo de implantação, a simplicidade operacional e de manutenção e a elevada eficiência na remoção de alguns atributos. No entanto, a eficiência do tanque séptico para remoção de matéria orgânica é limitada, havendo a necessidade de um pós-tratamento para alcançar um grau de remoção aceitável deste parâmetro (ALTVATER et al., 2009, COLARES e SANDRI, 2013).

Como alternativa de pós-tratamento aos tanques sépticos, pode-se fazer o uso de leitos cultivados. Nesses sistemas, a remoção de poluentes é decorrente de mecanismos físicos, químicos e biológicos que incluem, dentre eles, processos de sedimentação, filtração, absorção, precipitação e adsorção química, interações microbianas, extração de sais pelas plantas, volatilização e complexação (CHAGAS et al., 2011).

Um aspecto fundamental quando do uso de macrófitas em leitos cultivados é sua capacidade de absorver e transferir água para a atmosfera por meio da evapotranspiração, o que na maioria das vezes é negligenciado no cálculo do tempo de retenção hidráulico, sendo de fundamental importância na determinação da eficiência de remoção dos diferentes atributos presentes no efluente.

Para maximizar as vantagens do sistema de tratamento composto por tanques sépticos seguido de leitos cultivados, pesquisas devem ser desenvolvidas em diferentes regiões do Brasil, uma vez que fatores como dimensões dos componentes da estação de 
tratamento de esgoto (ETE), fatores hidráulicos, condições climáticas, espécies de macrófitas e sua adaptação às condições climáticas e a composição do esgoto, tempo de funcionamento em relação à sua implantação, dentre outros, interferem na eficiência de remoção de atributos presentes no esgoto.

Nessa perspectiva, no Distrito Federal e entorno são poucas as pesquisas sobre este tema. Diante disso, a Fazenda Água Limpa (FAL), pertencente à Universidade de Brasília (UnB), por fazer parte da Área de Proteção Ambiental (APA) das Bacias do Gama e Cabeça do Veado e tendo, no seu interior, a Área Relevante de Interesse Ecológico (ARIE) Capetinga/Taquara, demanda a implantação de uma estação de tratamento dos esgotos ali produzidos. Na FAL são feitas pesquisas de hidrologia na microbacia do Capetinga, avaliando-se a dinâmica das águas superficiais e subterrâneas em microbacias, com o objetivo de preservar o meio ambiente e manejar de forma racional os recursos da água e do solo, sendo este, mais um fator importante que justifica a implantação da ETE, visando minimizar danos aos recursos naturais, especialmente as águas subterrâneas.

Nos leitos cultivados, é importante a escolha correta das macrófitas a serem implantadas, sendo fundamental considerar fatores relacionados à tolerância em ambientes saturados de água (ou esgoto), seu potencial de crescimento, a presença dessas plantas nas áreas onde o sistema será implantado, pois, assim, as macrófitas estarão adaptadas às condições climáticas da área em questão, bem como o custo para o plantio e manutenção (poda regular, reaproveitamento, etc.) (IWA, 2000). Dentre as espécies disponíveis na região para implantação em leitos cultivados, e que ao mesmo tempo possuem potencial para fins paisagísticos, citam-se a taboa (Typha spp), papirobrasileiro (Cyperus giganteus) e lírio do brejo (Hedychium coronarium Koehne).

Diante do exposto, o objetivo deste trabalho é avaliar o desempenho inicial (5 meses) do tratamento de esgotos domésticos com três tanques sépticos em série, seguidos três leitos cultivados com diferentes espécies aquáticas e um sem plantas (testemunha). 


\section{OBJETIVOS}

\subsection{GERAL}

Avaliar na fase inicial, o desempenho de tanques sépticos em serie e leitos vegetados com diferentes espécies aquáticas.

\subsection{ESPECÍFICOS}

Avaliar a eficiência na remoção de atributos físicos, químicos e microbiológicos na entrada e saída do conjunto de três tanques sépticos em série e de leitos cultivados de fluxo subsuperficial, vegetados com taboa (leito 1), com papirobrasileiro (leito 2) e com lírio do brejo (leito 3) e um sem planta (leito 4).

Mensurar o desenvolvimento das macrófitas pela medida da altura das mesmas.

\section{REVISÃO DE LITERATURA}

\subsection{CARACTERIZAÇÕES DOS ESGOTOS E LEGISLAÇÃO DE RECURSOS HÍDRICOS}

Os esgotos domésticos são provenientes de residências, áreas comerciais ou qualquer edificação que contenha instalações de banheiros, lavanderias, cozinhas ou qualquer dispositivo de utilização de água para fins domésticos. São constituídos essencialmente de água de banho, urina, fezes, papel, restos de comida, sabão, detergentes e águas de lavagem. Os esgotos de origem doméstica são constituídos por cerca de $99,9 \%$ de água e apenas $0,1 \%$ de fezes, sabão, partículas de alimentos, sais presentes na urina, microrganismos, papel, plásticos, pó, areia, madeira compostos orgânicos e inorgânicos solúveis, colóides, etc. (JORDÃO \& PESSOA, 2009). Os principais componentes químicos, físicos e biológicos dos esgotos domésticos são, matéria orgânica, nutrientes, cloretos, óleos e graxas e patogênicos (METCALF e EDDY, 2003).

Quanto aos parâmetros representativos de matéria orgânica, cabe destacar a demanda bioquímica de oxigênio (DBO), a demanda química de oxigênio (DQO) e os sólidos. Normalmente a DBO de esgotos domésticos varia entre 100 e $400 \mathrm{mg} \mathrm{L}^{-1}$ e a DQO entre 200 e $800 \mathrm{mg} \mathrm{L}^{-1}$. De acordo com METCALF e EDDY (1991), a razão entre DBO/DQO varia entre 0,4 e 0,8 para esgoto doméstico. Os principais organismos encontrados nos rios e esgotos são as bactérias, fungos, protozoários, vírus, algas e 
grupos de plantas e animais. Desses organismos, os mais importantes são as bactérias, pois são responsáveis pela decomposição e estabilização da matéria orgânica (JORDÃO e PESSOA, 2009).

A poluição dos corpos hídricos causa queda nos níveis de oxigênio dissolvido, impactando toda a comunidade aquática, visto que a redução nos teores de oxigênio é seletiva para determinadas espécies. A poluição ainda pode causar eutrofização com consequente mortandade da biota aquática, elevação nos custos de tratamento da água e proliferação de algas (Von SPERLING, 2005).

As legislações brasileiras definem as responsabilidades pelo tratamento de efluentes e os padrões de qualidade das águas onde os efluentes tratados devem ser lançados. Em 8 de Janeiro de 1997 foi criada a Lei n. 9.433 que institui a Política Nacional de Recursos Hídricos, e o Sistema Nacional de Gerenciamento de Recursos Hídricos (BRASIL, 1997), regulamentando o inciso XIX do art. 21 da Constituição Federal. Destacam-se no artigo 21, que na fixação dos valores a serem cobrados pelo uso dos recursos hídricos devem ser observados os lançamentos de esgotos e demais resíduos líquidos ou gasosos, o volume lançado e seu regime de variação e as características físico-químicas, biológicas e de toxicidade do efluente.

Por sua vez, a Resolução Conama n. 357 de 17 de março de 2005 (BRASIL, 2005), em seu Art. 24, dispõe que os efluentes de qualquer fonte poluidora somente poderão ser lançados, direta ou indiretamente nos corpos de água, após o devido tratamento e desde que obedeçam às condições, padrões e exigências nela dispostos. Em seu artigo 27, a Resolução destaca que os efluentes não poderão conferir ao corpo de água receptor características em desacordo com as metas obrigatórias progressivas, intermediária e final, do seu enquadramento. O artigo 32, parágrafo $1^{\circ}$, relata que os efluentes não devem ocasionar a ultrapassagem das condições e padrões de qualidade de água estabelecidos para as respectivas classes, nas condições da vazão de referência. Segundo o artigo 34, proporcionar ou possuir potencial para causar efeitos tóxicos aos organismos aquáticos no corpo receptor, de acordo com os critérios de toxicidade estabelecidos pelo órgão ambiental competente deve ser evitado.

Entretanto, em 13 de maio de 2011 entrou em vigor a Resolução n. 430, que dispõe sobre as condições e padrões de lançamento de efluentes, complementando e alterando a Resolução n. 357, de 17 de março de 2005 (BRASIL, 2011). A Tabela 1 apresenta as condições de lançamento de efluentes estabelecidos e alteradas pelo 
Conama n. 430/2011. Em complementação ao artigo 16 da mesma resolução, esta traz os padrões de lançamento de efluentes para parâmetros inorgânicos.

TABELA 1. Condições de lançamento de efluentes em corpos hídricos superficiais conforme Resolução do Conama n.430/2011.

\begin{tabular}{|c|c|}
\hline Parâmetro & Condição de Lançamento de Efluentes \\
\hline $\mathrm{pH}$ & Entre 5 e 9 \\
\hline Temperatura & $\begin{array}{l}\text { Inferior a } 40^{\circ} \mathrm{C} \text {, sendo que a variação de temperatura do corpo } \\
\text { receptor não deverá exceder a } 3{ }^{\circ} \mathrm{C} \text { na zona de mistura. } \\
\text { Até } 1 \mathrm{~mL} \mathrm{~L} \mathrm{~L}^{-1} \text { em teste de } 1 \text { hora em cone Imhoff. Para o }\end{array}$ \\
\hline $\begin{array}{l}\text { Materiais } \\
\text { sedimentáveis }\end{array}$ & $\begin{array}{l}\text { lançamento em lagos e lagoas, cuja velocidade de circulação } \\
\text { deve está virtualmente ausentes, ou seja, praticamente nula, os } \\
\text { materiais sedimentáveis deverão. }\end{array}$ \\
\hline $\begin{array}{l}\text { Regime de } \\
\text { lançamento }\end{array}$ & $\begin{array}{l}\text { Vazão máxima de até } 1,5 \text { vezes a vazão média do período de } \\
\text { atividade diária do agente poluidor, exceto nos casos permitidos } \\
\text { pela autoridade competente. }\end{array}$ \\
\hline Óleos e graxas & $\begin{array}{l}\text { Óleos Minerais: até } 20 \mathrm{mg} . \mathrm{L}^{-1} \\
\text { Óleos vegetais e gorduras animais: até } 50 \mathrm{mg} . \mathrm{L}^{-1}\end{array}$ \\
\hline Materiais flutuantes & Ausência \\
\hline $\begin{array}{l}\text { Demanda Bioquímica } \\
\text { de Oxigênio (DBO) }\end{array}$ & $\begin{array}{l}\text { Remoção mínima de } 60 \% \text { de DBO sendo que este limite só } \\
\text { poderá ser reduzido no caso de existência de estudo de } \\
\text { autodepuração do corpo hídrico que comprove atendimento às } \\
\text { metas do enquadramento do corpo receptor. }\end{array}$ \\
\hline
\end{tabular}

Fonte: BRASIL (2011)

\subsection{FUNDAMENTOS DO TRATAMENTO DE ESGOTO COM TANQUE SÉPTICO}

Os tanques sépticos são dispositivos de tratamento amplamente difundidos e surgiram em 1895 na Inglaterra, tendo sido patenteados por D. Cameron. A sua finalidade básica é a remoção de matéria orgânica e os processos que ocorrem em seu interior são essencialmente: a sedimentação, a digestão anaeróbia da matéria orgânica e adensamento do lodo (ALTVATER, 2008).

No Brasil, o projeto, a construção e a operação de tanques sépticos são objeto de normatização específica da ABNT (BRASIL, 1997) que conceitua tanques sépticos como "unidade cilíndrica ou prismática retangular de fluxo horizontal para tratamento de esgotos por processos de sedimentação, flotação e digestão". As etapas de funcionamento dos tanques sépticos podem ser descritos da seguinte forma (CHERNICHARO, 1997): 
- Os sólidos sedimentáveis presentes no esgoto vão para o fundo do tanque, passando a constituir uma camada de lodo;

- Os óleos, graxas e outros materiais mais leves presentes no esgoto afluente flutuam até a superfície do tanque, vindos a formar uma camada de escuma;

- O esgoto, livre dos materiais sedimentáveis e flutuantes, flui entre as camadas de lodo e escuma, deixando o tanque séptico em sua extremidade oposta, de onde é encaminhado a uma unidade de pós-tratamento ou disposição final;

- O material orgânico retido no fundo do tanque sofre uma decomposição facultativa e anaeróbia, sendo convertido em compostos mais estáveis como $\mathrm{CO}_{2}, \mathrm{CH}_{4}$ e $\mathrm{H}_{2} \mathrm{~S}$. Embora $\mathrm{o}_{2} \mathrm{~S}$ seja produzido nos tanques sépticos, problemas de odor não são usualmente observados, uma vez que este se combina com metais acumulados no lodo, vindo a formar sulfetos metálicos insolúveis.

Nestes sistemas verifica-se a retenção de $60 \%$ a $70 \%$ de sólidos sedimentáveis responsáveis pela formação de lodo no fundo do digestor e escuma flotada para a superfície do líquido. Esse ambiente propício favorece a degradação ativa da matéria orgânica com baixa produção de biomassa, uma vez que o processo anaeróbio utiliza a maior parte da energia para o metabolismo anabólico, a atividade de degradação, obtendo-se como produtos finais metano e gás carbônico (CHERNICHARO, 1997). A eficiência do tanque séptico é moderada no que se refere à remoção da matéria orgânica e fraca na remoção de microrganismos patogênicos, porém na remoção de sólidos suspensos atinge boa eficiência (ALTVATER et al., 2009).

\subsection{MECANISMOS NO TRATAMENTO DE ESGOTO COM LEITOS CULTIVADOS COM MACRÓFITAS}

O sistema natural de tratamento de efluentes líquidos, chamado leitos cultivados com macrófitas (Constructed Wetlands), pode ser considerado como filtro biológico, onde atuam microrganismos aeróbios e anaeróbios, juntamente com plantas aquáticas fixadas ou não num meio de suporte. Como característica, o sistema apresenta grande capacidade de tratamento das águas residuárias e baixa produção de lodo. Esses sistemas foram criados para controlar sistematicamente o tratamento e aperfeiçoar a habilidade em remover ou transformar os poluentes dos efluentes (WOOD, 1995).

Os principais processos biológicos que regulam as remoções de nitrogênio e fósforo do efluente são a absorção direta pela macrófita, mineralização microbiológica e 
transformações como desnitrificação e amonificação (USEPA, 2000). A absorção direta ocorre, principalmente, pelo sistema radicular das macrófitas, embora algumas espécies de macrófitas possam também absorver nutrientes através das folhas (ESTEVES, 1998). Os principais processos abióticos que atuam nas remoções de nitrogênio e fósforo do efluente são a sedimentação, precipitação química e adsorção. A sedimentação também é importante na remoção de material particulado do efluente (BRASKERUD, 2002).

Uma série de vantagens podem ser descrita a partir da implementação de sistema de tratamento com leito cultivado, tais como: custo relativamente baixo de constituição e operação; fácil manutenção, tratamento efetivo e seguro de águas residuárias, são relativamente tolerantes a variações hidráulicas e de cargas de contaminantes; fornecem benefícios indiretos como área verde, habitat para pássaros e insetos e áreas recreativas e educacionais e para fins paisagísticos. As desvantagens são: demanda de área para construção (custo e disponibilidade satisfatórios de área), as recorrentes imprecisões para os critérios de design e operação, complexidade biológica e hidrológica do sistema e a falta de conhecimento da dinâmica dos processos de tratamento, os meios de enchimento e possíveis problemas com pragas nas tipologias superficiais. Mosquitos e outras pragas poderiam ser um problema para sistemas impropriamente projetados e operados, principalmente do tipo superficial (PHILIPPI e SEZERINO, 2004). Os parâmetros de projeto leitos cultivados são apresentados na Tabela 2.

TABELA 2. Critérios de projeto para os leitos cultivados de fluxo superficial (LCFS) e fluxo subsuperficial (LCFSS).

\begin{tabular}{|c|c|c|}
\hline Parâmetro & Fluxo Superficial & Fluxo Subsupercial \\
\hline Tempo de Detenção (dias) & $4-14$ & $2-7$ \\
\hline Altura de coluna d'água (m) & $0,1-0,5$ & $0,1-1,0$ \\
\hline Área por vazão $\left(\right.$ ha m$^{-3}$ dia $\left.^{-1}\right)$ & $0,002-, 014$ & $0,001-0,007$ \\
\hline Razão comprimento: largura do leito & $2: 1$ a $10: 1$ & $0,25: 1$ a $5: 1$ \\
\hline Controle de mosquitos & Requer & Não requer \\
\hline Frequência de colheita (ano) & $3-5$ & $3-5$ \\
\hline DBO máxima $\left(\mathrm{kg} \mathrm{ha}^{-1} \mathrm{dia}^{-1}\right)$ & 80 & 75 \\
\hline Carga hidráulica $\left(\mathrm{mm}^{3} \mathrm{~mm}^{2} \mathrm{dia}^{-1}\right)$ & $7-60$ & $2-30$ \\
\hline
\end{tabular}
Adaptado de WOOD e McATAMNEY (1996).

A remoção de poluentes nos leitos cultivados é realizada por processos físicos, químicos e biológicos, sendo realizados de modo concomitante e influenciados pelo tipo de fluxo do leito, pela planta cultivada, pelo meio suporte utilizado e pelas 
características da água residuária a ser tratada (VALENTIM, 1999). A descrição do comportamento de alguns atributos químicos em águas está descrito na sequência.

\subsubsection{Nitrogênio}

Nas águas naturais pode haver diversas fontes de nitrogênio, sendo elas: orgânico, amoniacal, nitrito e nitrato. As duas primeiras são chamadas de formas reduzidas e as duas últimas de formas oxidadas. Os compostos de nitrogênio são nutrientes para processos biológicos. Depois do carbono, o nitrogênio é o tributo químico exigido em maior quantidade de células vivas. Quando descarregados nas águas naturais conjuntamente com o fósforo e outros nutrientes presentes nos despejos provocam o enriquecimento do meio tornando-o mais fértil e possibilitam o crescimento em maior extensão dos seres vivos que os utilizam, especialmente as algas (CHEIS, 2014).

Ainda segundo o autor acima, o crescimento exagerado de populações de algas podem trazer prejuízos aos usos que se possam fazer dessas águas, prejudicando seriamente o abastecimento público ou causando poluição por morte e decomposição. $\mathrm{O}$ controle da eutrofização, através da redução do aporte de nitrogênio, é comprometido pela multiplicidade de fontes, algumas muito difíceis de serem controladas como a fixação do nitrogênio atmosférico, por parte de alguns gêneros de algas.

As principais fontes de nitrogênio em esgotos domésticos são orgânicas e amoniacais, e baixa concentração de nitrato. O nitrogênio amoniacal pode apresentar-se na forma livre $\left(\mathrm{N}-\mathrm{NH}_{3}\right)$ e ionizada $\left(\mathrm{N}-\mathrm{NH}_{4}{ }^{+}\right)$e a predominância de uma forma ou outra depende do $\mathrm{pH}$. $\mathrm{O}$ aumento do $\mathrm{pH}$ e da temperatura contribui para a elevação de fração não ionizada ou livre $\left(\mathrm{N}-\mathrm{NH}_{3}\right)$ e para a redução da fração ionizada $\left(\mathrm{N}_{-} \mathrm{NH}_{4}{ }^{+}\right)(\mathrm{SILVA}$, 2007; Von SPERLING, 1996). Valores de pH próximo de 8,0, praticamente todo o $\mathrm{N}$ amoniacal encontra-se na forma ionizada $\left(\mathrm{N}^{-} \mathrm{NH}_{4}{ }^{+}\right)$; próximo de 9,5, o N amoniacal é representado por, aproximadamente de $50 \%$ de $\left(\mathrm{N}_{-} \mathrm{NH}_{3}\right)$ e $50 \%$ de $\left(\mathrm{N}^{-\mathrm{NH}_{4}}{ }^{+}\right)$; com pH superior a 11, praticamente todo $\mathrm{N}$ está na forma de $\left(\mathrm{N}-\mathrm{NH}_{3}\right)$ (Von SPERLING, 1996).

As principais transformações que ocorrem com os compostos nitrogenados são: assimilação, amonificação, fixação biológica, nitrificação e desnitrificação. Os compostos incluem uma variedade de formas de nitrogênio inorgânico e orgânico que são essenciais para toda a vida biológica. As formas de nitrogênio inorgânico mais importante em sistemas de alagados construídos (SACs) são: amônio $\left(\mathrm{NH}_{4+}\right.$ ), nitrito $\left(\mathrm{NO}_{2-}\right)$ e nitrato $\left(\mathrm{NO}_{3-}\right)$. Nos SACs, pode existir também nitrogênio gasoso como: 
Nitrogênio molecular $\left(\mathrm{N}_{2}\right)$, óxido nitroso $\left(\mathrm{N}_{2} \mathrm{O}\right)$, óxido nítrico $\left(\mathrm{NO}_{2}\right.$ e $\left.\mathrm{N}_{2} \mathrm{O}_{4}\right)$ e amônia $\left(\mathrm{NH}_{3}\right)$. A somatória dessas formas de nitrogênio forma o nitrogênio total (N-Total). $\mathrm{O}$ nitrogênio orgânico e o nitrogênio amoniacal formam o denominado Nitrogênio Total Kjeldahl - NTK (COSTA, 2013).

A amonificação (mineralização) é o processo onde o nitrogênio orgânico é biologicamente convertido em amônia. $\mathrm{O}$ amoníaco é convertido a partir de formas orgânicas através de um complexo, liberando energia em multi-etapas dos processos bioquímicos. Os microrganismos utilizam essa energia para o seu crescimento, e amônia é diretamente incorporada em biomassa microbiana (KADLEC e KNIGHT, 1996). Na assimilação, o processo inverso ocorre (a amônia é incorporada à biomassa, estando presente, portanto, na forma de nitrogênio orgânico).

Nitrificação é geralmente definida como a oxidação biológica do amônio para nitrato e esta para nitrito como intermediário na sequencia de reação (PAUL e CLARK, 1996). Na primeira fase da nitrificação acontece a oxidação da amônia a nitrato por bactérias nitrificantes quimiossintéticas, principalmente do gênero Nitrosomonas, estritamente aeróbias (IWA, 2000).

$$
2 \mathrm{NH}_{4}^{+}+3 \mathrm{O}_{2} \stackrel{\text { Nitrosomonas }}{\longrightarrow} 2 \mathrm{NO}_{2}^{-}+4 \mathrm{H}^{+}+2 \mathrm{H}_{2} \mathrm{O}
$$

$\mathrm{Na}$ segunda fase da nitrificação, ocorre a oxidação de nitrito a nitrato. $\mathrm{O}$ processo é realizado por bactérias, principalmente do gênero Nitrobacter (IWA, 2000).

$$
2 \mathrm{NO}_{2}^{-}+\mathrm{O}_{2} \stackrel{\text { Nirobacter }}{\longrightarrow} 2 \mathrm{NO}_{3}^{-}
$$

O crescimento das Nitrosomonas é limitado pela concentração de amônio, enquanto que o crescimento das Nitrobacter é limitado pela concentração de nitrito. No entanto, a taxa de crescimento dos microrganismos nitrificantes, principalmente as do gênero Nitrosomonas, é bem lenta (Von SPERLING, 2007).

A concentração de nitrito gerado durante o processo de nitrificação é sempre pequena, uma vez que as bactérias Nitrosomonas requerem uma pequena quantidade de substrato (YÁNEZ, 1993). Além disso, quase não há acúmulo de nitritos, pois a taxa de crescimento das Nitrobacter é mais rápida do que a das Nitrosomonas e os nitritos, por serem muito instáveis no esgoto, oxidam-se facilmente para a forma de nitratos (EPA, 1983; JORDÃO e PESSÔA, 1995). Para ocorrer a nitrificação, as Nitrosomonas devem competir com as bactérias heterotróficas pelo oxigênio, assim a demanda bioquímica de 
oxigênio (DBO) da água deve ser menor que $20 \mathrm{mg} \mathrm{L}^{-1}$ para que a nitrificação significante possa ocorrer (CRITES et al., 2005).

A desnitrificação é a redução biológica de nitrato para nitrogênio molecular, tendo-se material orgânico como redutor. De acordo com Von SPERLING (2002), o processo de desnitrificação acontece em condições anaeróbias. As bactérias heterotróficas facultativas (ex: Pseudomonas), devido à ausência de oxigênio dissolvido, passam a utilizar os nitratos como aceptores de elétrons $\left(\mathrm{NO}_{3}{ }^{-} \mathrm{em}\right.$ substituição ao oxigênio), convertendo-os a $\mathrm{N}_{2}$, que escapa para a atmosfera, completando assim seu ciclo. A transformação de nitrato a nitrogênio orgânico é realizada conforme a seguir:

$$
2 \mathrm{NO}_{3}{ }^{-} \mathrm{N}+2 \mathrm{H}^{+} \longrightarrow \mathrm{N}_{2}+2,5 \mathrm{O}_{2}+\mathrm{H}_{2} \mathrm{O}
$$

\subsubsection{Fósforo}

Segundo Schlesinger (1991), o fósforo é um macronutriente essencial às plantas e aos animais, sendo um componente essencial do ADN (Ácido Desoxirribonucleico), ARN (Ácido ribonucleico), ATP (Trifosfato de adenosina) e fosfolipídios. Para ser assimilado pelas plantas, tem que estar na forma inorgânica, ou seja, na forma de íon ortofosfato $\left(\mathrm{PO}_{4}{ }^{3-}\right)$.

O fósforo pode se apresentar nas águas de três formas diferentes: os fosfatos orgânicos, os ortofosfatos e os polifosfatos ou fosfatos condensados. No entanto, a terceira forma não é relevante nos estudos de controle de qualidade das águas, porque os polifosfatos sofrem hidrólise, convertendo-se rapidamente em ortofosfatos nas águas naturais (CHEIS, 2014; APHA, 1995).

As principais formas de fósforo na água (Von SPERLING, 1996):

- Ortofosfatos: são diretamente disponíveis para o metabolismo biológico sem necessidade de conversões a formas mais simples, sendo apresentados nas formas $\mathrm{PO}_{4}{ }^{3}$-, $\mathrm{HPO}_{4}{ }^{2}$ - (mais comum em $\mathrm{pH}$ 6,5 e 7,5), $\mathrm{H}_{2} \mathrm{PO}_{4^{-}}, \mathrm{H}_{3} \mathrm{PO}_{4}$. As principais fontes são o solo, detergentes, fertilizantes, despejos industriais e esgoto doméstico (degradação da matéria orgânica);

- Polifosfatos: são moléculas mais complexas com dois ou mais átomos de fósforo, sendo que se transformam em ortofosfatos pelo mecanismo da hidrólise, mas tal transformação é usualmente lenta; 
- Fósforo orgânico: é normalmente de menor importância nos esgotos domésticos típicos, mas pode ser importante em águas residuárias industriais e lodos oriundos do tratamento de esgotos. No tratamento de esgotos e nos corpos d'água receptores o fósforo orgânico é convertido a ortofosfatos.

O fósforo presente nos esgotos domésticos $\left(5\right.$ a $\left.20 \mathrm{mg} \mathrm{L}^{-1}\right)$ tem procedência, principalmente, da urina dos contribuintes e do emprego de detergentes usualmente utilizados nas tarefas de limpeza. Este fósforo apresenta-se principalmente nas formas de ortofosfato, poli ou pirofosfatos e fósforo orgânico. Cerca de $80 \%$ do total são de fósforo inorgânico, 5 a $15 \mathrm{mg} \mathrm{L}^{-1}$ (poli + orto), enquanto que o orgânico varia de 1 a $5 \mathrm{mg} \mathrm{L}^{-1}$ (FERNANDES, 1997).

Segundo Akratos e Tshirintzis (2007), a remoção de fósforo ocorre essencialmente por absorção das plantas e através da precipitação e adsorção por parte do meio de enchimento, incluindo os detritos. Diferentemente do nitrogênio e do carbono, o fósforo não pode ser perdido nas zonas radiculares por processos metabólicos, não havendo perdas pela forma gasosa.

A retirada pelas plantas pode ser significante em sistemas de baixa-taxa e fluxo superficial, quando a colheita da vegetação é praticada rotineiramente. Nestes casos a colheita pode representar de $20 \%$ a $30 \%$ da remoção de fósforo, porém a vegetação usada nos leitos cultivados não é considerada um fator significante na remoção de fósforo. Pois sendo realizada a colheita nos leitos de fluxo superficial o fósforo volta para o sistema aquático devido ao decaimento natural da vegetação. A remoção de fósforo por aguapés e outras plantas aquáticas fica limitado às necessidades das plantas não excedendo 50\% a 70\% do fósforo presente no afluente (REED et al., 1995).

As reações de adsorção e precipitação, em geral, são as formas de maior remoção de fósforo dos efluentes, quando este entra em contato com um volume significante solo ou sedimentos. As reações no solo envolvem certos elementos como a argila, os óxidos de ferro e alumínio, os componentes de cálcio presentes e o pH do solo. Solos de textura muito fina, bem como os de alto teor de argila, tendem a ter um alto potencial de adsorção, mas aumentam o tempo hidráulico de residência. A brita e a areia por possuírem textura grosseira têm baixa capacidade de adsorção do fósforo, e os solos hidromórficos, que são ácidos e orgânicos, têm um elevado potencial de adsorção devido à presença de ferro e alumínio (REED $\underline{\text { et al., }}$ 1995). 


\subsubsection{Condutividade elétrica}

A condutividade é uma expressão numérica da capacidade de uma água conduzir a corrente elétrica. Depende das concentrações iônicas e da temperatura e indica a quantidade de sais existentes na d'água, e, portanto, representa uma medida indireta da concentração de poluentes. Em geral, níveis superiores a $100 \mu \mathrm{S} \mathrm{cm} \mathrm{cm}^{-1}$ indicam ambientes impactados. A condutividade também fornece uma boa indicação das modificações na composição de uma água, especialmente na sua concentração mineral, mas não fornece nenhuma indicação das quantidades relativas dos vários componentes. À medida que mais sólidos dissolvidos são adicionados, a condutividade da água aumenta. Altos valores podem indicar características corrosivas da água (CETESB, 2009).

\subsubsection{Potencial Hidrogeniônico (pH) e Alcalinidade}

$\mathrm{O}$ pH influi em diversos equilíbrios químicos que ocorrem naturalmente ou em processos unitários de tratamento de águas. A sua influência sobre os ecossistemas aquáticos naturais dá-se diretamente devido a seus efeitos sobre a fisiologia das diversas espécies. Também o efeito indireto é muito importante podendo, em determinadas condições de $\mathrm{pH}$, contribuírem para a precipitação de elementos químicos tóxicos como metais pesados; outras condições podem exercer efeitos sobre as solubilidades de nutrientes (CETESB, 2009). A Resolução CONAMA nº 357 de 2005, determina as condições de lançamento de efluentes em corpos hídricos, a faixa de pH entre 5 a 9.

Alcalinidade, que é a medida da capacidade do líquido em neutralizar ácidos, é resultante da presença de ácidos fracos, bases e seus sais derivados, e seu teor nos esgotos, está ligado à qualidade da água de abastecimento. Devido a capacidade de atuar como tampão contra a queda de $\mathrm{pH}$, a alcalinidade é um importante parâmetro na caracterização do esgoto doméstico e, principalmente no esgoto industrial, tendo em vista que o bom desempenho do tratamento biológico adotado depende muito da manutenção das condições de neutralidade do pH (FERNANDES, 1997).

\subsubsection{Oxigênio dissolvido}

O oxigênio dissolvido é de essencial importância para os organismos aeróbios (que vivem na presença de oxigênio). Esses organismos fazem uso do oxigênio nos seus processos respiratórios durante a estabilização reduzindo a sua concentração no meio. É 
o principal parâmetro de caracterização dos efeitos da poluição das águas por despejos orgânicos (Von SPERLING, 2005).

\subsubsection{Demanda Bioquímica de Oxigênio}

A demanda biológica de oxigênio (DBO) é um parâmetro que indica a quantidade de oxigênio necessária para oxidar a matéria orgânica biodegradável presente na água, sob condições aeróbicas, ou seja, avalia a quantidade de oxigênio dissolvido (OD) em $\mathrm{mg} \mathrm{L}^{-1}$ de $\mathrm{O}_{2}$, que será consumido pelos organismos aeróbios ao degradarem a matéria orgânica (JORDÃO et al., 2007; LIMA et al., 2006). Se a quantidade de matéria orgânica é pequena, as bactérias decompositoras necessitarão de pouco oxigênio para decompô-la e então, a DBO será baixa (PEREIRA, 2004).

Segundo os padrões de qualidade de água, estabelecidos na Resolução CONAMA n. 357 (Brasil, 2005), os valores máximos de DBO para as águas de classes 1,2 e 3 são 3,0; 5,0 e 10,0 $\mathrm{mg} \mathrm{L}^{-1}$, respectivamente.

Os maiores aumentos em termos de DBO, num corpo d'água, são provocados por despejos de origem predominantemente orgânica. A presença de um alto teor de matéria orgânica pode induzir ao completo esgotamento do oxigênio na água, provocando o desaparecimento de peixes e outras formas de vida aquática (CETESB, 2009).

\subsubsection{Demanda Química de Oxigênio}

Demanda Química de Oxigênio (DQO) é indicador de matéria orgânica baseado na concentração de oxigênio consumido para oxidar a matéria orgânica, biodegradável ou não, em meio ácido e condições energéticas por ação de um agente químico oxidante forte. Esta técnica apenas estima a concentração de matéria orgânica em termos de oxigênio consumido já que nos corpos d'águas as condições não são tão energéticas, além do fato de que algumas espécies inorgânicas, tais como nitritos, compostos reduzidos de enxofre e substâncias orgânicas - como hidrocarbonetos aromáticos, compostos alifáticos de cadeia aberta e piridinas - não são oxidadas (VALENTE et al., 1997).

A principal diferença com relação ao teste da DBO e DQO, é que aquele o teste relaciona-se a uma oxidação bioquímica da matéria orgânica, realizada inteiramente por microorganismos, enquanto que a DQO corresponde a uma oxidação química da 
matéria orgânica, obtida através de um forte oxidante (dicromato de potássio) em meio ácido, esclarece (Von SPERLING, 1996).

A DQO é um parâmetro indispensável nos estudos de caracterização de esgotos sanitários e de efluentes industriais. A DQO é muito útil quando utilizada conjuntamente com a DBO para observar a biodegradabilidade de despejo (CETESB, 2009).

\subsection{UTILIZAÇÃO DE MACRÓFITAS NO TRATAMENTO DE ESGOTO}

As plantas aquáticas ou macrófitas aquáticas são vegetais que ocorrem em ambientes úmidos, de uma forma geral, sem levar em consideração agrupamento taxonômicos específico (ESTEVES, 1998). O termo macrófita inclui desde as plantas aquáticas vasculares (angiospermas, como a taboa (Typha spp.) até algumas algas cujos tecidos podem ser visivelmente identificados. Como todos os outros organismos fotoautotróficos, utilizam energia solar para assimilar carbono inorgânico da atmosfera e produzir matéria orgânica que servirá de fonte de energia para seres heterotróficos animais, bactérias e fungos (BRIX, 1997).

Uma grande variedade de macrófitas aquáticas podem ser utilizadas no tratamento de esgoto em sistemas de leitos cultivados com fluxo subsuperficial (LCFSS). A escolha da macrófita está relacionada à tolerância da planta quanto aos ambientes saturados de água (ou esgoto), seu potencial de crescimento, a presença destas plantas nas áreas onde o sistema será implantado (pois assim as macrófitas estarão adaptadas às condições climáticas da área em questão), bem como o custo para o plantio e a manutenção (IWA, 2000; LIN et al., 2005).

A classificação dos leitos cultivados é feita de acordo com o tipo ecológico predominante das macrófitas aquáticas utilizadas, sendo que as macrófitas emersas e flutuantes as mais utilizadas (KIVAISI, 2001). Quando povoados com macrófitas emersas, necessitam de solo para fixação da planta e podem possuir camadas de brita, cascalho, areia fina e areia grossa abaixo do solo (LIN et al., 2005). Por sua vez, com macrófitas flutuantes não necessitam de solo para a fixação da planta.

Segundo Brix (1997), ao longo das últimas décadas, com a intensificação dos estudos e as aplicações de leitos cultivados, muitas foram às ações atribuídas às macrófitas, dentre elas: estabilização da superfície do filtro; promoção de boas condições para o processo físico de filtração; aeração da rizosfera (região de contato 
entre solo e raízes); promoção de área disponível para aderência de microrganismos nas raízes; retirada de nutrientes devido ao requerimento nutricional das plantas; harmonia paisagística.

De uma forma geral, os benefícios das macrófitas no tratamento de efluentes podem ser assim sumarizados (VALENTIM, 1999): Estético, pois o benefício da vegetação em comparação a um filtro de solo ou de pedras na redução de materiais orgânicos e sólidos suspensos é a estética e o apelo ecológico da unidade de várzea; Controle de odor: as plantas, associadas com os sedimentos, agem como um biofiltro de odor; tratamento de efluentes por promover um tratamento aeróbio e anaeróbio do efluente, retirando sólidos suspensos e microrganismos patogênicos. Para Almeida (2010), a utilização de plantas aquáticas no tratamento de esgotos constitui-se em alternativa eficiente e de baixo custo aos sistemas convencionais.

Vários experimentos têm demonstrado que os minerais podem ser absorvidos diretamente pelos brotos de plantas submersas. No entanto, também não há dúvida sobre a capacidade de captação de nutrientes pelas raízes dessas plantas (VYMAZAL, 1995). A capacidade de macrófitas enraizadas para utilizar os nutrientes do sedimento pode parcialmente ser responsável por sua maior produtividade em comparação com os sistemas planctônicos (WETZEL, 2001).

As concentrações de nutrientes da vegetação tendem a ser maiores no início da estação de crescimento, diminuindo à medida que a planta madura senesce. Padrões de mudanças sazonais na composição variam tanto para as espécies e os nutrientes, provavelmente, uma generalização não pode ser feita (VYMAZAL, 1995).

A taxa potencial de absorção de nutrientes pelas plantas é limitada pela sua produtividade líquida (taxa de crescimento) e a concentração de nutrientes no tecido vegetal. Estocagem de nutrientes é igualmente dependente de concentrações de nutrientes das plantas, tecidos e também sobre o potencial final para acumulação de biomassa, ou seja, a colheita. Portanto, características desejáveis de uma planta usada para a assimilação de nutrientes e armazenamento incluiria um crescimento rápido, alto conteúdo de nutrientes dos tecidos, e a capacidade de atingir uma colheita de pé alto (REDDY e DEBUSK, 1987).

Dentre as espécies de macrófitas, a Taboa (Typha ssp) é uma das mais pesquisadas no Brasil. É uma planta emergente, perene, que chega a 2 até $4 \mathrm{~m}$ de altura, possui rizoma rasteiro e pode ser encontrada em diversos habitats aquáticos. Além do fácil cultivo, possui crescimento surpreendente em substratos ricos em matéria orgânica. 
Pioneira nos estudos de tratamento de águas residuárias, é capaz de remover cargas orgânicas até metais pesados e auxiliar no controle de erosão nas margens de canais (POTT, 2000).

A multiplicação se dá por rizomas e sementes, sendo a inflorescência em espiga contínua ou interrompida, apresentando coloração escura (CORDAZZO; SEELIGER, 1988). Segundo Mulamoottil et al. citado em Mannarino(2006), destacam a taboa (Typha ssp.) como própria para utilização em wetlands por sua estrutura interna ser formada por tecidos que contém espaços abertos, através dos quais acontece transporte de oxigênio da atmosfera para as folhas e daí para as raízes e rizomas. Parte do oxigênio pode ainda sair do sistema radicular para a área em torno da rizosfera criando condições para decomposição aeróbia da matéria orgânica, bem como para crescimento de bactérias nitrificantes.

O papiro-brasileiro (Cyperus giganteus) pertence à família das Cyperaceae é originário do Brasil e tem ciclo perene. O papiro-brasileiro é uma excelente planta palustre, isto é, adapta-se e cria um efeito excelente em lagos, fontes e espelhos de água. Apresenta hastes longas com uma cabeleira de folhas finas nas pontas. Deve ser cultivado a pleno sol. Multiplica-se através da divisão das touceiras, preservando a estrutura completa da planta, com rizoma, raízes e hastes (PATRO, 2012).

A planta de lírio do brejo (Hedychium coronarium Koehne), da família das Zingiberaceae, é uma planta herbácea rizomatosa, perene, vigorosa, entouceirada com 1,5 a 2,0 m de altura, com o caule ereto e avermelhado na base, enfolhado. Folhas sésseis, lanceoladas. O lírio do brejo é utilizado para diversos fins, desde ornamentação, pela beleza das flores; produção de papel, pois a haste contém de 43 a $48 \%$ de celulose (FACUNDO e MOREIRA, 2005); também pode ser usado na limpeza de esgotos (ALMEIDA e ALMEIDA, 2005).

\subsection{MEIO DE SUPORTE DOS LEITOS CULTIVADOS}

Segundo Borges (2007), o substrato (leitos) não serve apenas como local de fixação das plantas, mas como filtro na depuração dos poluentes, sendo usado como substrato frequentemente brita, areia, cascalho, argila e material orgânico. A escolha do material utilizado como substrato deve estar condicionada às finalidades do tratamento proposto, levando-se em conta a viabilidade econômica, condições de fluxo e potencial reativo (PHILIPPI e SEZERINO, 2004). 
A relação entre o meio suporte e a eficiência do tratamento do efluente se dá pelo resultado da integração entre as interações físicas (filtração e sedimentação), químicas (adsorção de compostos orgânicos dissolvidos) e biológicas (transformações bioquímicas e bioacumulação de elementos químicos) que ocorrem nos leitos devido à presença das comunidades bacterianas, onde ocorre a proliferação de biofilmes (LEITÃO, 2005).

Segundo Chernicharo (1997), a finalidade do material suporte é a de reter sólidos no interior do leito, seja através do biofilme formado na superfície do material suporte, seja através da retenção de sólidos nos interstícios do meio ou abaixo deste. São as principais finalidades da camada suporte: ajuda a promover a uniformização do escoamento do reator; melhorar o contato entre os constituintes do despejo de afluente e os sólidos biológicos no reator, permitir o acúmulo de grande quantidade de biomassa, aumentando, assim, o tempo de retenção celular, atuar como barreira física, evitando que os sólidos sejam carregados para fora do sistema de tratamento, elevada área específica e porosidade, resistência a colmatação, baixo preço, atuar como um dispositivo para separar sólidos dos gases.

Ressalta-se que, independentemente do meio suporte utilizado, os sistemas de tratamento de efluentes devem ter sua base cuidadosamente impermeabilizada para evitar a contaminação das águas subterrâneas com esgoto. Em sistemas de escoamento superficial consegue-se melhor aderência das plantas ao leito quando utilizado como material suporte solo ou areia. Já para sistemas de fluxo subsuperficial é indicado material que permita mais facilmente a manutenção da permeabilidade do leito, dificultando a colmatação dos poros, onde se recomenda a pedra britada (ZANELLA, 2008).

O material usado como substrato deve ser capaz de manter ao longo do tempo boas condições de fluxo (condutividade hidráulica) bem como o potencial reativo capaz de adsorver compostos inorgânicos como a amônia $\left(\mathrm{NH}_{3}\right)$ e ortofosfato $\left(\mathrm{PO}_{4}{ }^{3-}\right)$ (PHILIPPI e SEZERINO 2004).

\subsection{EVAPOTRANSPIRAÇÃO DOS LEITOS COM MACRÓFITAS}

As plantas absorvem água do esgoto e a liberam para a atmosfera, num processo denominado transpiração, que somado à água evaporada da superfície do solo constituem a evapotranspiração (ET). O processo ocorre nas estações de tratamento de 
esgoto com plantas, eliminando ou reduzindo o volume do esgoto (TRUONG et al., 2008).

Em ambientes propícios a elevados índices de ET e durante períodos mais secos, é possível ocorrer uma redução de efluente à saída do sistema, até atingir-se vazões nulas. Assim, a ET requer suprimento de energia, proveniente da radiação solar. Portanto, é mais elevada no verão, quando os dias são mais longos e a radiação solar é maior. Nos trópicos, a energia solar e a evapotranspiração, no curso do ano, são significativamente mais elevadas que em regiões de clima temperado (CAMARGO e CAMARGO, 2000).

A evapotranspiração tem como consequência a redução temporária do nível de água, um aumento do tempo de retenção hidráulico (TRH) e um aumento da concentração dos poluentes (USEPA, 2000). Segundo Collischonn (2001), os principais fatores atmosféricos que afetam a evaporação são: a radiação solar, a temperatura, a umidade relativa do ar e a velocidade do vento.

\section{MATERIAL E MÉTODOS}

\subsection{CARACTERIZAÇÃO DO LOCAL DO EXPERIMENTO}

O experimento foi desenvolvido na Fazenda Água Limpa (FAL) da Universidade de Brasília (UnB) (15057'16”S, 4755'89'W e altitude de $1.103 \mathrm{~m}$ ), que atende funcionários de campo, técnicos administrativos, estudantes e professores da Faculdade de Agronomia e Medicina Veterinária (FAV), do Instituto de Biologia (IB), da Engenharia Florestal (EFL), do Instituto de Geologia, do Departamento de Física, dentre outros usuários, onde foi construída a Estação de Tratamento de Esgoto (ETE). O clima local é caracterizado como tropical estacional (Aw), segundo Köppen-Geiger, que tem como característica a sazonalidade do regime de chuvas, com um período chuvoso de outubro a abril e um período seco de maio a setembro (SANTANA et al., 2010).

\subsection{ORIGEM DO ESGOTO BRUTO}

$\mathrm{Na}$ FAL/UnB, são gerados esgotos, prioritariamente de descargas sanitárias (dois vasos sanitários femininos e dois masculinos) e do refeitório, que, pela sua composição é caracterizado essencialmente como esgoto doméstico, sendo estas as únicas fontes de 
esgoto destinadas ao tratamento, não sendo derivado à ETE/FAL/UnB nenhum efluente de laboratórios. O volume diário gerado na FAL/UnB é muito variável, devido à frequência de uso pela oscilação de pessoas que frequentam a FAL, e também não é equânime entre os dias da semana, sendo que no final de semana, feriados e períodos de férias da UnB, a geração de esgoto é insignificante.

\subsection{DESCRIÇÃO DA ESTAÇÃO DE TRATAMENTO DO EFLUENTE}

\subsubsection{Condução do esgoto e descrição geral da ETE/FAL/UnB}

A ETE/FAL/UnB é constituída por dois níveis: tratamento primário e secundário. O tratamento primário foi constituído de um conjunto de três tanques sépticos em série, e o tratamento secundário por um conjunto de três unidades de leitos cultivados e um leito sem planta (testemunha) de fluxo subsuperficial, construídos em paralelo e independentes um do outro, preenchido com brita \# 2 (Figura 1).

$\mathrm{O}$ efluente gerado no refeitório da FAL passa inicialmente por uma caixa de gordura antes de ser conduzido à ETE/FAL/UnB. A condução do esgoto bruto desde os pontos de geração até a ETE/FAL/UnB foi feito por tubulação de Policloreto de Vinila (PVC), de 0,15 m de diâmetro, própria para condução esgoto.

A diferença de nível do local de captação do esgoto localizado (sanitários coletivos) e próximo ao refeitório (após a caixa de gordura) até a entrada no primeiro tanque séptico é de $215 \mathrm{~m}$, com declividade média de 4,3\%, portanto, superior ao recomendado pela norma da ABNT, BRASIL (1997).

O efluente após passar pelos leitos cultivados foi direcionado até uma caixa de fibra de vidro (reservatório) com volume total de 5000 L e útil de 4750 L. Desse reservatório, o efluente é bombeado para reúso em irrigação, quando da existência de pesquisas em campo com culturas irrigadas e o excedente é conduzido para valas de infiltração como sendo o destino final. 


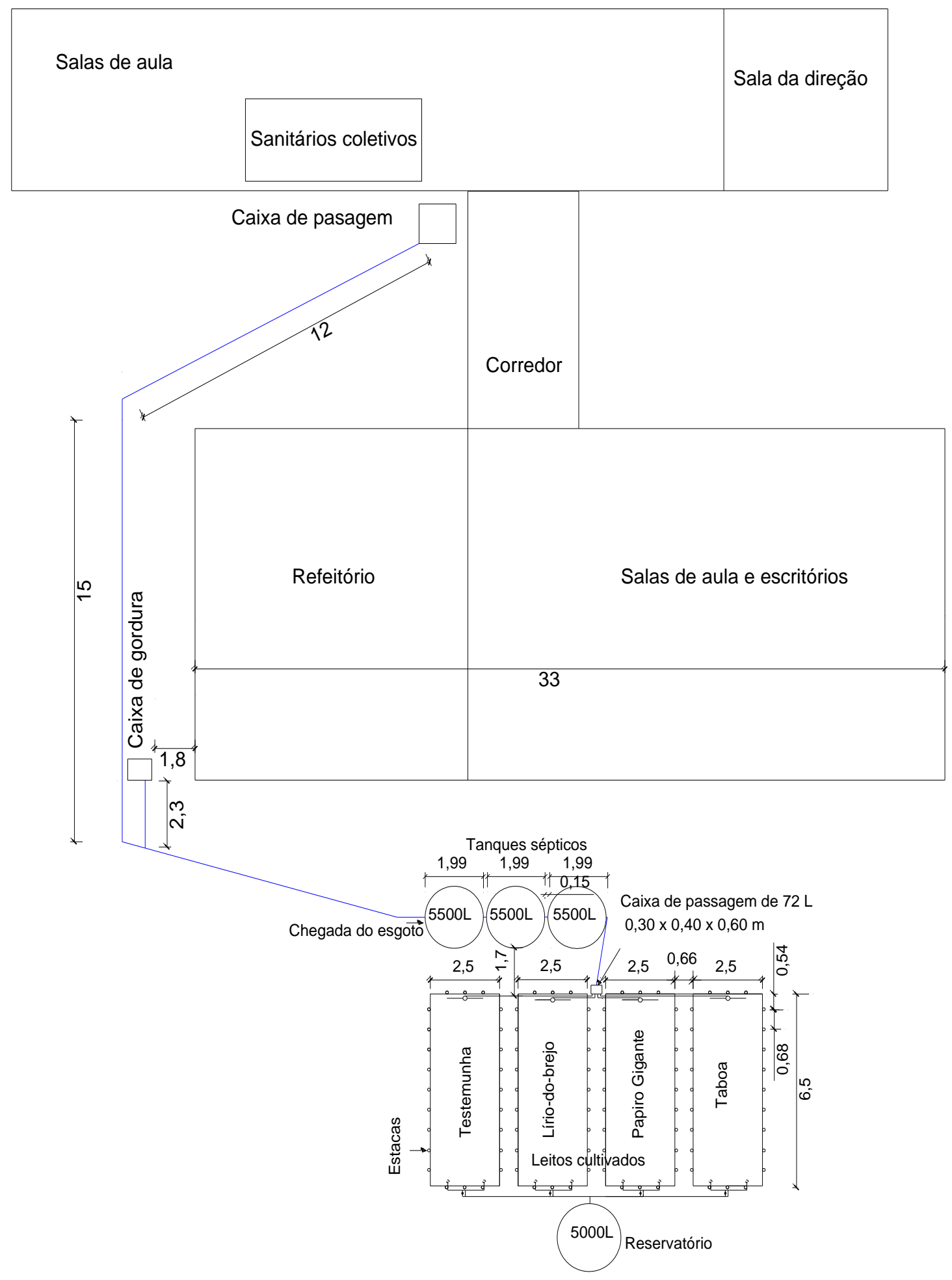

FIGURA 1. Localização de algumas dependências da FAL e planta baixa da estação de tratamento de esgoto (ETE/FAL/UnB).

\subsection{Tanques sépticos em série}

O conjunto de três tanques sépticos em série, é destinado ao tratamento primário do esgoto gerado na FAL/UnB, e constituídos de caixas de PVC, com tampa roscável, 
com volume total individual de 5500 L (Figura 2a e 2b) e volume total dos três tanques (Vt) de $16500 \mathrm{~L}$, porém, considerando os pontos de entrada e saída de esgoto em cada tanque (Figura 3), o volume útil de cada tanque é de 5100 L, ou seja, 15300 L de volume útil total. Os tanques sépticos (caixas) foram parcialmente enterrados no solo, possibilitando a entrada do esgoto bruto por gravidade e, ao mesmo tempo, dispostas com pequena diferença de nível $(0,075 \mathrm{~m})$, entre cada um dos tanques sépticos, ou seja, corresponde a diferença de nível de nível entre a entrada e saída de um mesmo tanque, porém, a tubulação de ligação dos tanques está na horizontal.
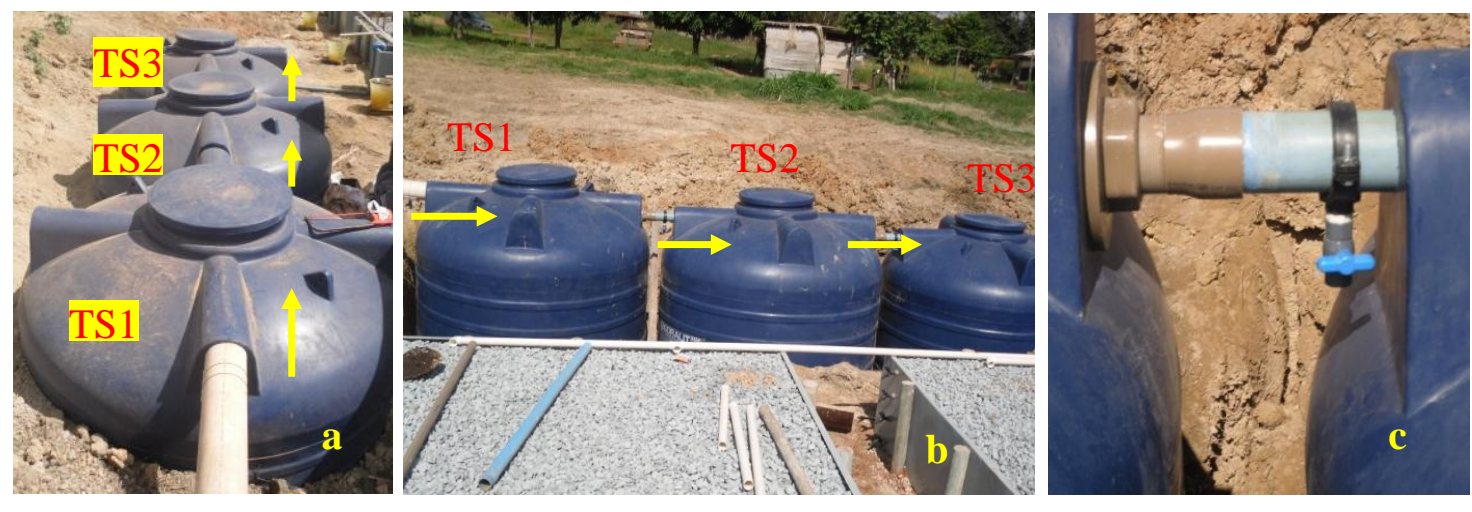

FIGURA 2. Vista dos três tanques sépticos (TS1, TS2 e TS3) e indicação do sentido de escoamento do esgoto (a e b) e ponto de coleta de esgoto (c).

Antes do primeiro TS e entre um TS e outro, na parte inferior do tubo de ligação dos mesmos foi instalado um "colar hidráulico" e um registro de gaveta de 1/2", permitindo a coleta de amostras de efluente (Figura 2c). Porém, por questões operacionais e laboratoriais, optou-se por avaliar os atributos somente no esgoto bruto (P1) e na saída do TS3 (P2) (Tabela 3), sendo este considerado como o efluente de entrada nos leitos de cultivo (Figura 3).

TABELA 3. Descrição dos pontos de coleta nos tanques sépticos em série (TS).

\begin{tabular}{lc}
\hline Ponto & Característica \\
\hline Ponto 1 & Efluente bruto (EBR) \\
Ponto 2 & Saída do TS 3 (TS3) \\
\hline
\end{tabular}

Conforme ABNT, BRASIL (1997) que descreve sobre o posicionamento do dispositivo de entrada de esgoto no tanque séptico, estes devem estar mergulhados verticalmente no líquido, a fim de evitar perturbações hidráulicas no interior do tanque e direcionar o fluxo de esgoto para o fundo, possibilitando uma melhor sedimentação dos sólidos.

Assim, na entrada do TS 1 (chegada do esgoto bruto) foi utilizado um tubo de $0,15 \mathrm{~m}$ de diâmetro posicionado na vertical, com $1 \mathrm{~m}$ de comprimento, sendo $0,8 \mathrm{~m}$ 
mergulhado no esgoto, já nas entradas dos TS 2 e TS 3 foram usados tubos de 0,075 m, com 0,7 m de comprimento e na saída dos três tanques utilizaram-se tubos, também de 0,075 m e 0,60 m de comprimento (Figura 3). Os tanques sépticos (caixas) possuem formato circular com 1,99 m de diâmetro e 1,99 m de altura total (Figura 3).

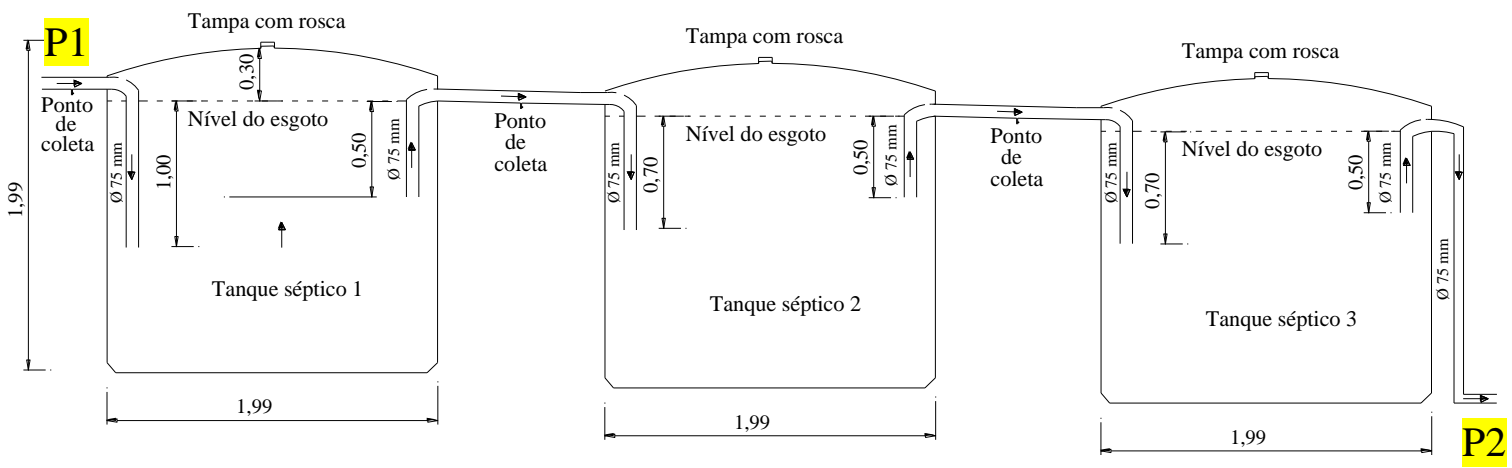

FIGURA 3. Vista em corte dos três tanques sépticos instalados em série e pontos de coleta de esgoto para análise (P1 e P2).

Antes do início de entrada de esgoto bruto nos tanques sépticos foram adicionados em cada um $10 \mathrm{~kg}$ de esterco de bovino, com o objetivo de acelerar a proliferação de microrganismos e o processo inicial de decomposição da matéria orgânica.

\subsubsection{Caixa de passagem e leitos cultivados}

A caixa de passagem do efluente para os leitos cultivado foi construída em fibra de vidro com capacidade total de $72 \mathrm{~L}(0,30 \mathrm{~m}, 0,40 \mathrm{~m}, 0,60 \mathrm{~m}$ - largura, comprimento e altura) (Figura 4a), de onde saem quatro tubos de PVC para esgoto com diâmetro de 0,040 m, um para cada leito de cultivo (Figura 4b). Para melhorar o controle da vazão de entrada em cada leito cultivado, implantou-se vertedouro triangular, com ângulo interno de $80^{\circ}$, sendo este o único ponto de controle da vazão, assim, a distribuição das vazões independe da inclinação dos tubos de condução do efluente para cada leito de cultivo, já que funciona não afogado.
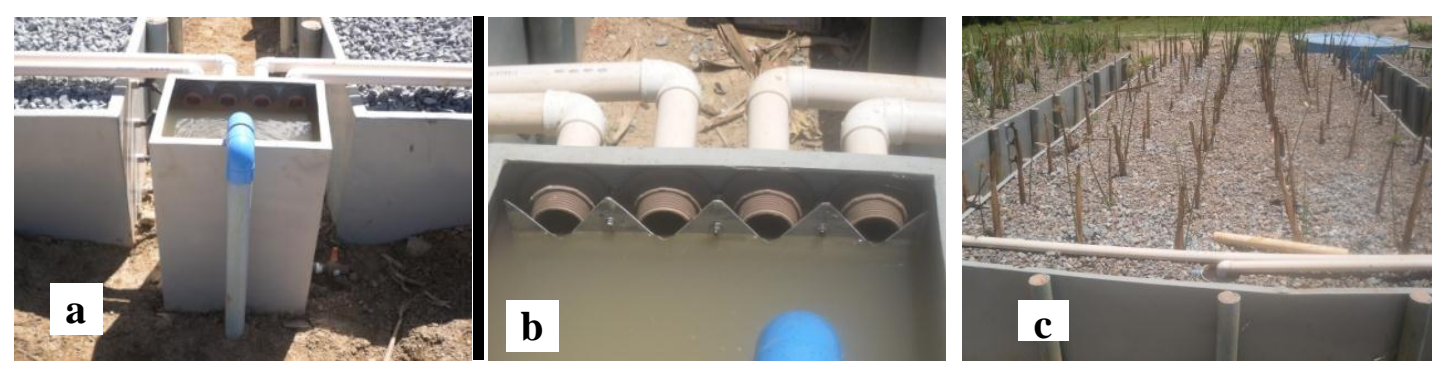

FIGURA 4. Caixa de passagem para os leitos cultivados (a), vertedouros triangular no interior da caixa de passagem (b) vista dos leitos cultivados com plantas recémtransplantadas e do leito não cultivado (c). 
Os leitos cultivados foram construídos em estruturas retangulares de fibra de vidro, com espessura da parede de $4 \mathrm{~mm}$ (Figura 5a), apoiados sobre o solo, com dimensões de 2,5 m (largura), 6,5 m (comprimento) e 0,5 m (altura).

Para melhorar a distribuição de efluente nos leitos de cultivo, instalou-se um tubo de $40 \mathrm{~mm}$ desde a caixa de passagem, com inclinação de aproximadamente $1 \%$, de onde o efluente caia em um reservatório enterrado na brita no centro da largura do leito, de onde saem 2 tubos de 1/2", um para cada lado, com comprimento de 1/4 da largura do leito (Figura 5b).
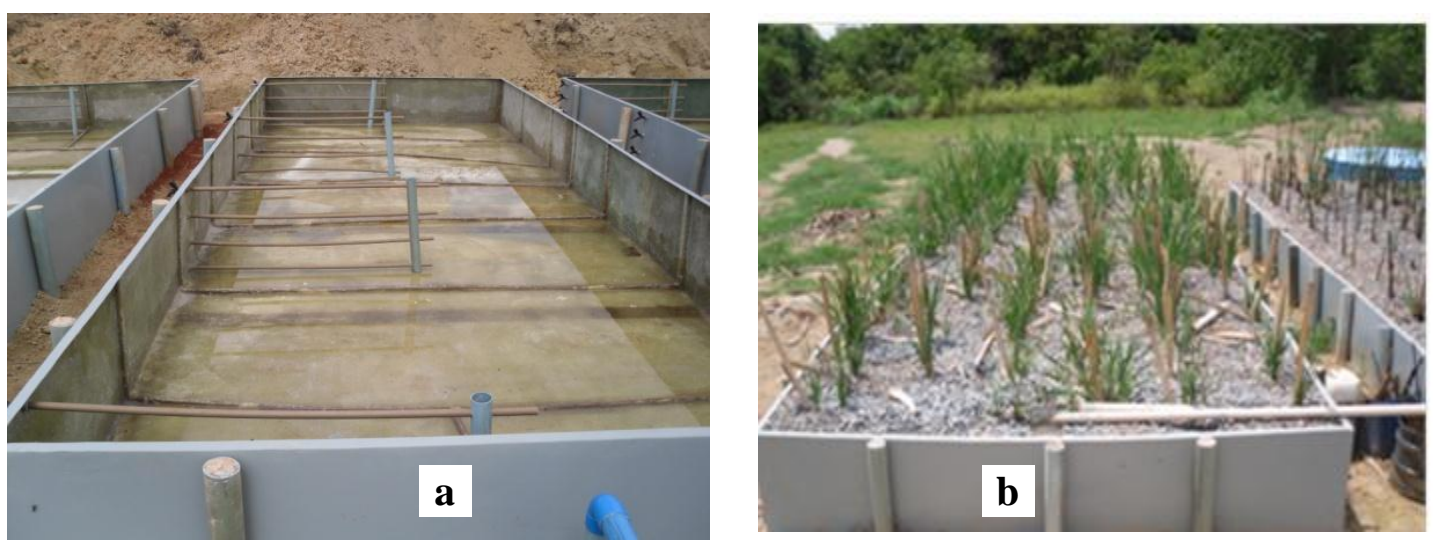

FIGURA 5. Vista interna dos leitos antes do preenchimento com brita (a) e sistema de distribuição de água nos leitos cultivados (b).

O controle do nível do efluente nos leitos foi feito a partir de um tubo de PVC com 0,050 m de diâmetro, que sai do fundo de cada leito (saída do efluente) e se eleva até uma altura de $0,047 \mathrm{~m}$, mantendo o nível do efluente aproximadamente de 0,003 m abaixo da superfície das caixas utilizadas como LC (folga), e, na sequência, retorna ao nível do solo (Figura 6a a 6c), de onde segue por uma tubulação até a caixa de fibra de vidro de 5000 L, localizada após os LC e leito sem cultivo, servindo como reservatório para uso do efluente em projetos de reúso na irrigação e passagem para as valas de infiltração (destino final do efluente tratado). Para cada leito de cultivo instalou-se um cavalete de saída, independente um do outro, permitindo a coleta de amostras de efluente individualmente para cada leito, contendo um "colar hidráulico" e um registro de esfera de 1/2" (Figura 6c e 6d). A altura da base do tubo que regula a altura do nível da água nos LC é $0,10 \mathrm{~m}$ mais altos que a base do tubo de entrada do EET no reservatório. 

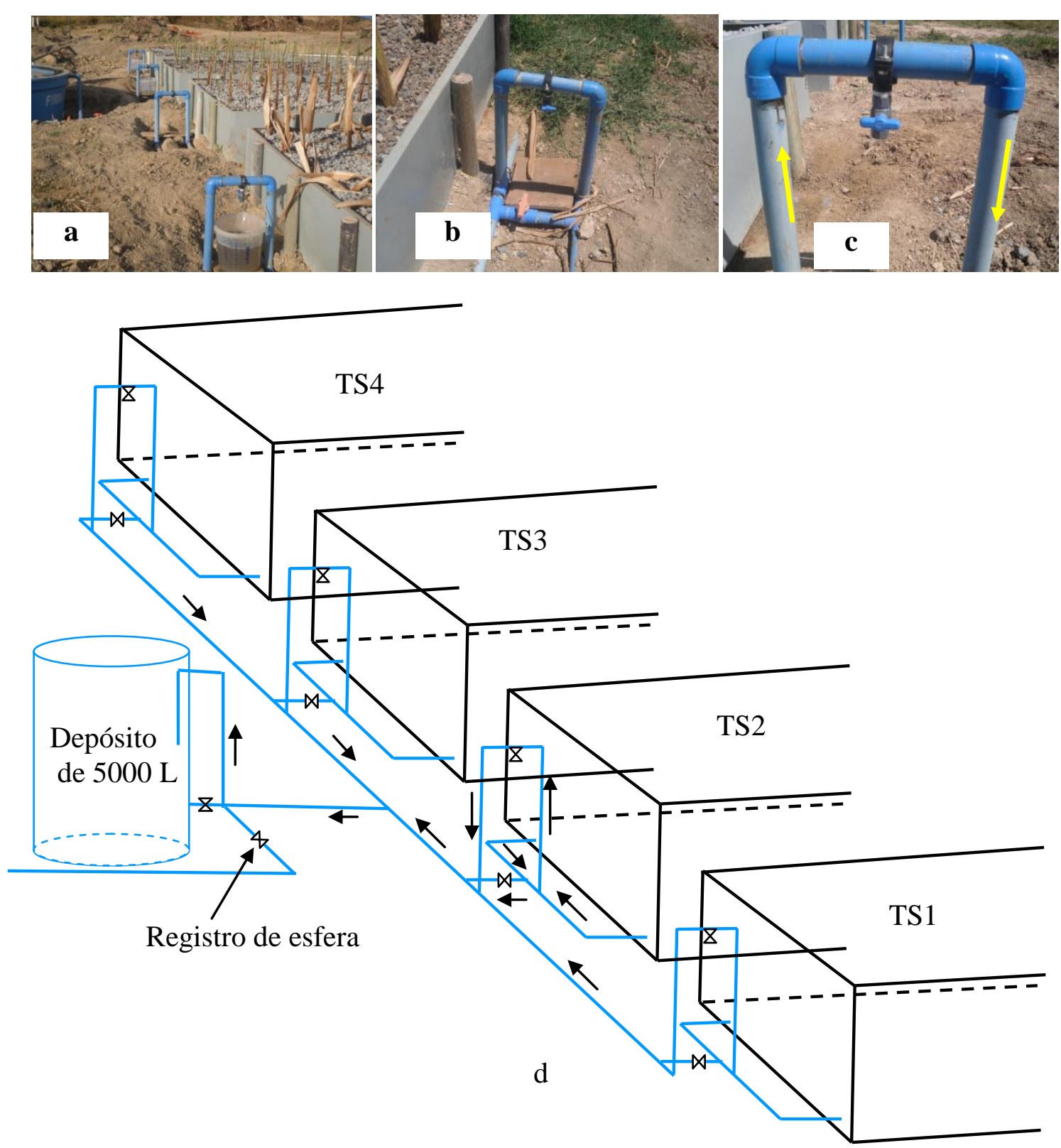

FIGURA 6. Vista dos cavaletes de controle do nível do efluente no interior dos leitos de cultivo e pontos de coleta dos leitos em campo (a, b e c) e em um "croqui" do sistema (d) mostrando o sentido do fluxo do efluente.

A Tabela 4 apresenta descrição das dimensões dos leitos cultivados, critério de projetos sugeridos por WOOD e McATAMNEY (1996) e dados obtidos com informações de vazão quantificadas em diferentes dias de coleta nos leitos fluxo subsuperficial da ETE/FAL/UnB.

Considerou-se área superficial total dos leitos de 0,0065 ha, volume total dos leitos de $30,55 \mathrm{~m}^{3} \mathrm{dia}^{-1}$, porém, sabendo que a porosidade de $50 \%$ da brita $\mathrm{n} .2$, que

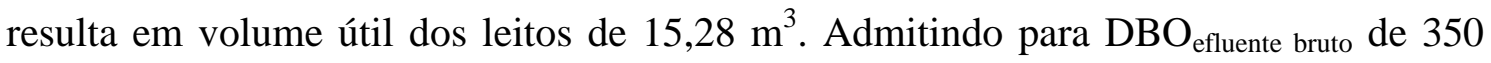
$\mathrm{mgO}_{2} \mathrm{~L}^{-1}$, eficiência do tanque séptico de 0,6 ou $60 \%$ como valores fixos, mas 
variando-se o volume de esgoto conforme medidas feitas in loco, sendo este considerado como o volume útil $\left(\mathrm{m}^{3} \mathrm{dia}^{-1}\right)$, obtém-se os valores dos parâmetros calculados conforme Tabela 4. A altura da coluna de água nos leitos sugerida por WOOD e McATAMNEY (1996) é de 0,1 a 1,0 m, sendo que neste trabalho foi de 0,47 m. Ainda segundo os autores, leitos cultivados preenchidos com substrato não requerem o controle de mosquitos, porém devem evitar a exposição do efluente na superfície dos leitos. A razão comprimento: largura sugerida pelos autores é de 0,25:1 a 5:12, sendo o utilizado de 2,60:1. Quanto à colheita da macrófitas, a frequência sugerida é de 3 a 5 anos, no entanto, deve-se observar in loco o comportamento de cada espécie para definir o momento adequado para realização da colheita, que varia entre as espécies.

TABELA 4. Descrição dos critérios de projeto e informações utilizadas no dimensionamento dos leitos cultivados da ETE/FAL/UnB para fluxo subsuperficial.

\begin{tabular}{lcc}
\hline \multicolumn{1}{c}{ Parâmetros } & Critérios de projeto* & $\begin{array}{c}\text { Dados de } \\
\text { dimensionamento } \\
\text { do projeto }\end{array}$ \\
\hline $\mathrm{Q}\left(\mathrm{m}^{3} \mathrm{dia}^{-1}\right)$ & - & 6,5 \\
Tem de Detenção Hidráulica (dias) & 2 a 7 & 2,35 \\
Área por vazão $\left(\mathrm{ha} \mathrm{m}^{-3} \mathrm{dia}^{-1}\right)$ & 0,001 a 0,007 & 0,001 \\
Carga Hidráulica $\left(\mathrm{mm}^{3} \mathrm{~mm}^{-2} \mathrm{dia}^{-1}\right)$ & 2 a 30 & 100 \\
DBO máxima $\left(\mathrm{kg} \mathrm{ha}^{-1} \mathrm{dia}^{-1}\right)$ & 75 & 52,5 \\
\hline
\end{tabular}

(*Adaptado de WOOD e McATAMNEY, 1996)

Os parâmetros foram obtidos conforme Equações seguintes, sendo os cálculos apresentados para a vazão de $6,5 \mathrm{~m}^{3} \mathrm{dia}^{-1}$, como sendo as informações utilizadas para dimensionamento da ETE.

\section{- Tempo de detenção (TD) (dias)}

$\mathrm{TD}=\frac{\mathrm{V}_{\text {útil }}}{\mathrm{Q}_{\text {leito }}}=\frac{\text { Área }_{\text {leito }} * \% \text { Poros }_{\text {brita }}}{\mathrm{Q}_{\text {leito }}}=\frac{(2,5 \mathrm{~m} * 6,5 \mathrm{~m} * 0,5 \mathrm{~m} * 0,5)}{1625 \mathrm{~m}^{3} \text { dia }^{-1}}=2,35$ dias

- Área por vazão (AQ) $\left(\mathrm{ha} \mathrm{m}^{3}\right.$ dia $\left.^{-1}\right)$

$\mathrm{AQ}=\frac{\text { Área }_{\text {leito }}}{\mathrm{Q}_{\text {leito }}}=\frac{\frac{(2,5 \mathrm{~m} * 6,5 \mathrm{~m})}{10000 \mathrm{~m}^{2}}}{1,625 \mathrm{~m}^{3} \mathrm{dia}^{-1}}=0,0010 \mathrm{ha} \mathrm{m}^{3} \mathrm{dia}^{-1}$ 


\section{- Carga Hidráulica $(\mathrm{CH})\left(\mathrm{mm}^{3} \mathrm{~mm}^{2} \mathrm{dia}^{-1}\right)$}

$$
\mathrm{CH}=\frac{1,625 \frac{\mathrm{m}^{3}}{\mathrm{dia}} * 1 \times 10^{9} \frac{\mathrm{mm}^{3}}{\mathrm{~m}^{3}}}{(2,5 \mathrm{~m} * 6,5 \mathrm{~m}) * 1 \times 10^{9} \frac{\mathrm{mm}^{2}}{\mathrm{~m}^{2}}}=100 \mathrm{~mm}^{3} \mathrm{~mm}^{2} \mathrm{dia}^{-1}
$$

$$
\begin{aligned}
& \text { - DBO }{ }_{\text {máxima ( }} \text { kg ha dia }{ }^{-1} \text { ) }
\end{aligned}
$$

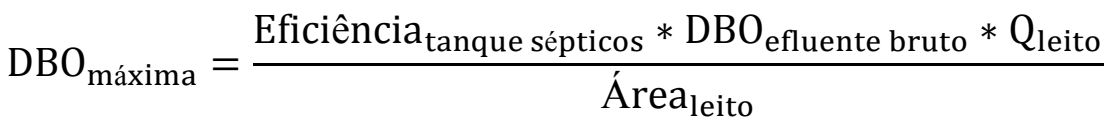

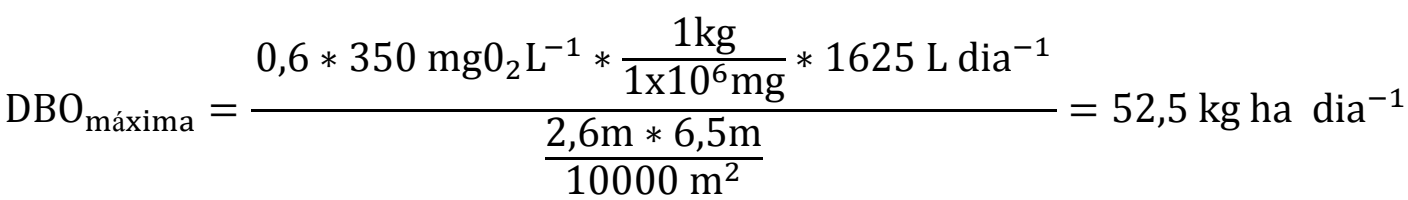

Para garantir estabilidade nas paredes das caixas de fibra de vidro (leitos cultivados), foram instaladas estacas de concreto de $1,20 \mathrm{~m}$ de altura e $0,075 \mathrm{~m}$ de diâmetro (tubos de PVC preenchidos com concreto), em que, 0,70 m foram enterrados no solo. Foram fixadas estacas a 0,54 das extremidades das caixas no sentido do comprimento e as demais a cada 0,68 m (Figura 7a), já no sentido da largura, as estacas foram colocadas a $0,60 \mathrm{~m}$ da extremidade e as demais a cada 0,65 m (Figura $7 \mathrm{~b}$ ), totalizando 24 estacas por leito de cultivo, num total de 96 para os quatro leitos.
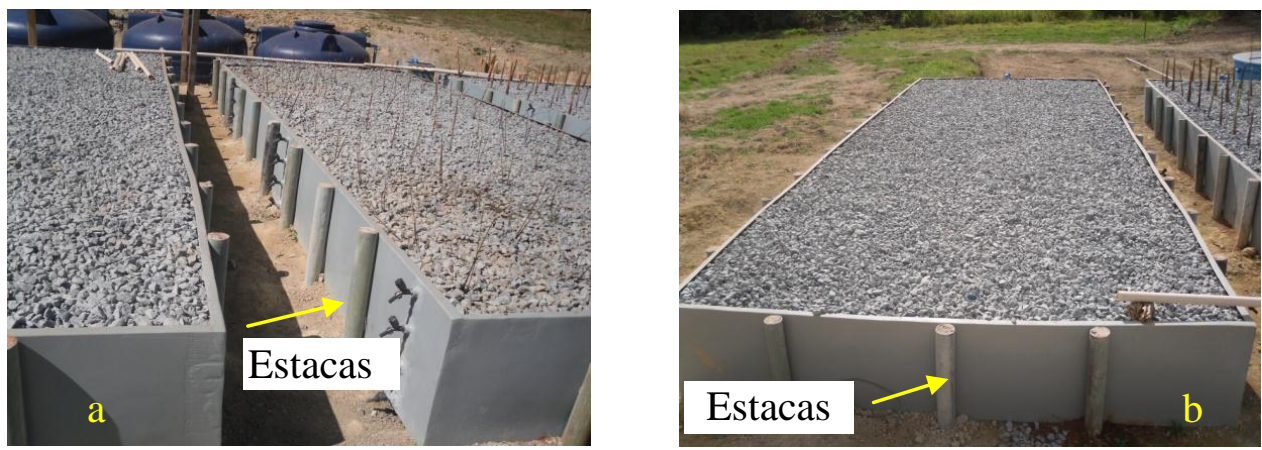

FIGURA 7. Estacas de sustentação dos leitos cultivados no sentido do comprimento (a) e no sentido da largura (b).

Os leitos cultivados foram simplesmente apoiados sobre o solo nivelado e compactado para evitar aprofundamento do solo e não interferir na estabilidade da estrutura dos leitos construídos em fibra de vidro.

Os pontos de coleta nos leitos cultivados (LC) são apresentados na Tabela 5. 
TABELA 5. Localização dos pontos de coleta do afluente e efluente para análise tanques sépticos e nos leitos cultivados.

\begin{tabular}{ll}
\hline Ponto & Localização \\
\hline Ponto 1 & Efuente Bruto (EBR) \\
Ponto 2 & Saída do Tanque Séptico 3 e entrada dos leitos \\
Ponto 3 & Saída do leito 1 cultivado com taboa (LC 1) \\
Ponto 4 & Saída do leito 2 cultivado com papiro-brasileiro (LC 2) \\
Ponto 5 & Saída do leito 3 cultivado com lírio-do-brejo (LC 3) \\
Ponto 6 & Saída do leito 4 sem cultivo (LNC 4) \\
\hline
\end{tabular}

\subsection{COLETAS DAS AMOSTRAS DE EFLUENTE E PARÂMETROS AVALIADOS}

Foram realizada amostra composta, em horários estabelecidos, a fim de se obter uma amostra mais representativa, devido a variabilidade da composição do esgoto e volume de esgoto gerado na FAL. Os horários de coleta definitivos foram: 9:00 h , 11:00 h e 13:00 h, nas datas de: 20/08; 08/09; 21/09; 06/10; 21/10; 05/11; 20/11 e 07/12/2015 ( repetições) totalizando 48 amostras analisadas. Porém, os parâmetros pH, condutividade elétrica (CE), temperatura e oxigênio dissolvido (OD) foram analisado in loco em todos os horários de coleta. Em campo, também se analisou Sólidos Sedimentáveis, realizado no cone Imhoff, segundo o Standard Methods (APHA, 1995), fornecendo leituras em $\mathrm{mL} \mathrm{L}^{-1}$.

As amostras foram coletadas em frascos de plástico de volume de $1 \mathrm{~L}$, acondicionadas em caixa de isopor com gelo, transportadas para o laboratório e conservadas em geladeira, conforme recomendações do Standard Methods, com excessão dos parâmetros que exigem determinação no mesmo dia.

Todas as amostras foram submetidas a análises físicas, químicas e microbiológicas (Tabela 6). Para a realização das análises laboratoriais, foram utilizados os Laboratórios de Ànálise de Água da FAV/UnB e outros laboratórios disponíveis na FAV e de outras faculdades e institutos da UnB, uitlizando as metodologias de análise do Standard Métods for the Examination of Water and Wastewater (APHA, AWWA, WPCF, 2005), conforme apresentadas na Tabela 6. 
TABELA 6. Parâmetros analisados e seus respectivos métodos de análise para frequência de análise quinzenal.

\begin{tabular}{|c|c|c|c|}
\hline Atributo & Símbolo & Unidade & Método de análise \\
\hline $\begin{array}{l}\text { Potencial } \\
\text { Hidrogeniônico }\end{array}$ & $\mathrm{pH}$ & - & Eletroquímico \\
\hline Condutividade elétrica & $\mathrm{CE}$ & $\mathrm{dS} \mathrm{m}^{-1}$ & Condutivímetro \\
\hline Sólidos Suspensos & SS & $\mathrm{mg} \mathrm{L}^{-1}$ & Gravimétrico \\
\hline Sólidos Totais & $\mathrm{ST}$ & $\mathrm{mg} \mathrm{L}^{-1}$ & Gravimétrico \\
\hline Sólidos sedimentáveis & SSD & $\mathrm{mg} \mathrm{L}^{-1}$ & Gravimétrico \\
\hline Oxigênio dissolvido & OD & $\mathrm{mg} \mathrm{L}^{-1}$ de $\mathrm{O}_{2}$ & Eletrométrico: Oxímetro \\
\hline $\begin{array}{l}\text { Demanda Química de } \\
\text { Oxigênio }\end{array}$ & DQO & $\mathrm{mg} \mathrm{L}^{-1}$ de $\mathrm{O}_{2}$ & Colorimétrico de refluxo fechado \\
\hline $\begin{array}{l}\text { Demanda Bioquímica } \\
\text { de Oxigênio }\end{array}$ & $\mathrm{DBO}$ & $\mathrm{mg} \mathrm{L}^{-1}$ & Titulométrico \\
\hline Alcalinidade Total & - & $\begin{array}{c}\mathrm{mg} \mathrm{L}^{-1} \mathrm{de} \\
\mathrm{CaCO}_{3}\end{array}$ & Titulométrico \\
\hline Sódio & $\mathrm{Na}^{+}$ & $\mathrm{mg} \mathrm{L}^{-1}$ & Espectrofotômetro de chama \\
\hline Potássio & $\mathrm{K}^{+}$ & $\mathrm{mg} \mathrm{L}^{-1}$ & Espectrofotômetro de chama \\
\hline Nitrito & $\mathrm{NO}_{2}^{-}$ & $\mathrm{mg} \mathrm{L}^{-1}$ & Espectrofotométrico \\
\hline Nitrato & $\mathrm{NO}_{3}^{-}$ & $\mathrm{mg} \mathrm{L}^{-1}$ & Espectrofotométrico \\
\hline Amônia & $\mathrm{NH}_{3}$ & $\mathrm{mg} \mathrm{L}^{-1}$ & Espectrofotométrico \\
\hline Fosfato Total & $\mathrm{PO}_{4}^{3-}$ & $\mathrm{mg} \mathrm{L}^{-1}$ & Espectrofotométrico \\
\hline Turbidez & Turb & NTU & Espectrofotométrico \\
\hline Ferro & $\mathrm{Fe}$ & $\mathrm{mg} \mathrm{L}^{-1}$ & Espectrofotométrico \\
\hline $\begin{array}{l}\text { Coliformes } \\
\text { Termotolerantes }\end{array}$ & CTermo & NMP $100 \mathrm{~mL}^{-1}$ & $\begin{array}{l}\text { Substrato Cromogênico (APHA- } \\
1995 \text { ) }\end{array}$ \\
\hline Coliformes Totais & CT & NMP $100 \mathrm{~mL}^{-1}$ & $\begin{array}{c}\text { Substrato Cromogênico (APHA- } \\
1995 \text { ) }\end{array}$ \\
\hline
\end{tabular}

Coliformes totais e $\boldsymbol{E}$. coli - a quantificação de coliformes totais e $E$. coli foi realizada pelo método do substrato cromogênico. Os equipamentos usados na análise foram a cartela Quanti-Tray, seladora Quanti-sealer e lâmpada UV do método conhecido comercialmente como Colilert-IDEXX e uma estufa biológica. O método produz respostas dentro de 24 a 28 horas de incubação. Os procedimentos experimentais, os materiais necessários e o método estão descritos no Standard Methods (APHA, 1995).

\subsection{MANEJO DAS MACRÓFITAS NOS LEITOS DE CULTIVO}

$\mathrm{Na}$ primeira semana de agosto de 2015 (entre os dia 08 e 10) foram transplantadas 102 mudas de macrófitas em cada leito, sendo a taboa (Typha spp) em um dos leitos (Leito de cultivo 1), outro com papiro-brasileiro (Cyperus giganteus) no Leito 2 e um com Lírio do brejo (Hedychium coronarium Koehne) no Leito 3 (Figuras 8a, 8 b e 8c), sendo que o leito 4 ficou como testemunha ( sem o cultivo de macrófita), 
respectivamente. A Figura 9 mostra as macrófitas aos 120 após serem transplantadas, em que, visivelmente muitas plantas morreram especialmente no início dos leitos cultivados (entrada do afluente).

Em cada leito foram transplantados 102 mudas, espaçadas a $0,20 \mathrm{~m}$ da borda dos leitos, 0,42 $\mathrm{m}$ entre plantas no sentido da largura e 0,37 $\mathrm{m}$ entre plantas no sentido do comprimento, totalizando 17 fileiras no sentido transversal com 6 mudas cada uma. As plantas foram removidas do seu ambiente natural, transportadas até o local do experimento em sacos plásticos e mantidas com água até o plantio e tiveram suas folhas cortadas a $0,50 \mathrm{~m}$ de altura e transplantadas imediatamente nos leitos com sistema radicular e transplantadas a $0,10 \mathrm{~m}$ abaixo da superfície da brita.
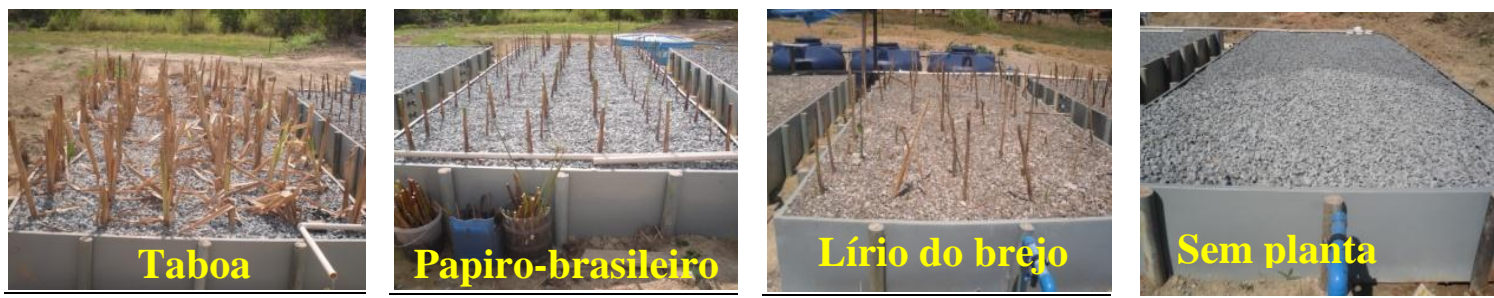

FIGURA 8. Vista do leito cultivado com taboa (Leito 1), papiro-brasileiro (Leito 2), lírio do brejo (Leito 3) após o plantio e leito sem plantas (Leito 4), no transplantio.
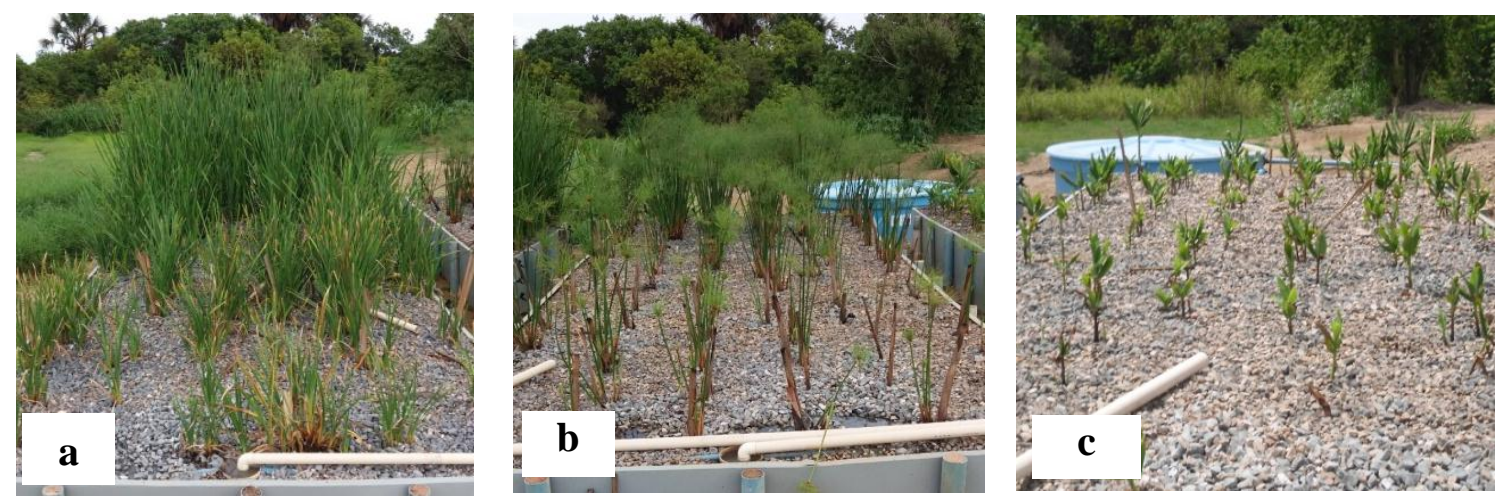

FIGURA 9. Vista dos leitos cultivados: taboa (a), papiro - brasileiro (b), lírio do brejo (c), aos 120 dias após o transplantio.

\subsubsection{Desenvolvimento das plantas}

Cada leito de cultivo foi dividido em 4 blocos de 24 plantas (4 fileiras com 6 plantas), totalizando 96 plantas avaliadas, excluindo-se a $1^{\circ}$ fileira de cada leito para manter mesmo número de plantas por bloco.

Para medir o desenvolvimento das plantas optou-se em medir a altura das mesmas, em datas preestabelecidas, diferentes das coletas de amostras do efluente para 
análises, usando uma trena métrica, com precisão de $1 \mathrm{~mm}$, medida da superfície da brita até a ponta da folha mais alta.

O diâmetro do caule foi medido com um paquímetro digital, com precisão de 0,0001 m, medindo-se o colmo da planta mais alta da touceira, a uma altura de 0,02 m da superfície da brita.

\subsection{VAZÃO DE ENTRADA E SAIDAS NOS LEITOS}

Para a determinação da vazão de entrada e saída nos leitos cultivados para cada espécie de macrófita, foi feita entre horário das 08:00 às 18:00 h; nos mesmo dia das coletas de eflente para análises físicas, químicas e microbiológicas, ou seja, a cada 15 dias (Tabela 6), dados usados para estimar o tempo de retenção hidráulica (TDH) de cada leito de cultivo.

Para medir a vazão de entrada e saída dos leitos de cultivos, utilizou-se o método volumétrico, utilizando um balde graduado de $10 \mathrm{~L}$, com precisão de $1 \mathrm{~L}$ e auxílio de um cronômetro digital para marcar o tempo. Toda vez que o volume de $10 \mathrm{~L}$ era atingido, o efluente era lançado nos leitos de cultivo no caso da vazão de entrada e para a vazão de saída, eram despejados num reservatório, de onde eram conduzidos para as valas de infiltração.

\subsection{DADOS METEOROLÓGICOS DO PERÍODO DO EXPERIMENTO}

A Tabela 7 apresenta os valores da precipitação, temperatura do ar e radiação solar nas datas de coleta dos dados em campo. Os dados foram obtidos da Estação Meteorológica Automática da FAL/UnB ( Fazenda Água Limpa), em Brasília - DF, localizada a $500 \mathrm{~m}$ da ETE/FAL.

TABELA 7. Valores de precipitação, temperatura máxima, temperatura mínima e radiação solar nas datas de coleta em campo. 


\begin{tabular}{cccccc}
\hline Data & $\begin{array}{c}\text { Precipitação } \\
(\mathrm{mm})\end{array}$ & $\begin{array}{c}\text { Temperatura } \\
\text { máxima }\left({ }^{\circ} \mathrm{C}\right)\end{array}$ & $\begin{array}{c}\text { Temperatura } \\
\text { mínima }\left({ }^{\circ} \mathrm{C}\right)\end{array}$ & $\begin{array}{c}\text { Temperatura } \\
\text { média }\left({ }^{\circ} \mathrm{C}\right)\end{array}$ & $\begin{array}{c}\text { Radiação Solar } \\
\left(\mathrm{MJ} \mathrm{m}^{-2}\right)\end{array}$ \\
\hline $20 / 08 / 2015$ & 0 & 30,0 & 11,5 & 20,75 & 15,6 \\
$08 / 09 / 2015$ & 0,5 & 30,1 & 17,6 & 23,85 & 8,3 \\
$21 / 09 / 2015$ & 0 & 33,5 & 9,2 & 21,35 & 22,1 \\
$06 / 10 / 2015$ & 0 & 34,2 & 16,3 & 25,25 & 19,4 \\
$21 / 10 / 2015$ & 0 & 35,1 & 14,8 & 24,95 & 16,1 \\
$05 / 11 / 2015$ & 2,2 & 32,2 & 14,8 & 23,50 & 21,0 \\
$20 / 11 / 2015$ & 18,4 & 28,4 & 17,9 & 23,15 & 14,7 \\
$07 / 12 / 2015$ & 3,8 & 34,6 & 17,0 & 25,80 & 16,4 \\
\hline
\end{tabular}

As temperaturas médias variando entre $20,75^{\circ} \mathrm{C}$ a $25,25^{\circ} \mathrm{C}$, já com relação à variação de temperatura máxima e mínima, observam-se valores similares entre as datas de coleta de dados, com valores máximos entre $28,2{ }^{\circ} \mathrm{C}$ a $35,1{ }^{\circ} \mathrm{C}$ e mínimos entre 11,5 ${ }^{\circ} \mathrm{C}$ e $17,9{ }^{\circ} \mathrm{C}$, com exceções ao dia $21 / 09 / 2015$, onde foi de $9,2{ }^{\circ} \mathrm{C}$ para temperatura mínima (Tabela 7). De maneira geral, altas temperaturas favorecem a produção primária por acelerarem as reações químicas metabólicas das macrófitas aquáticas (GENEVIEVE et al., 1997), ao mesmo tempo, tem implicações diretas na evapotranspiração das plantas.

\subsection{ANÁLISE DOS RESULTADOS}

Os resultados obtidos foram submetidos ao cálculo de eficiência de remoção, utilizando a Equação1.

$$
\mathrm{E}=\frac{\mathrm{Ce}-\mathrm{Cs}}{\mathrm{Ce}} 100
$$

Em que:

$\mathrm{E}=$ eficiência de remoção $(\%)$

$\mathrm{Ce}=$ concentração na entrada

$\mathrm{Cs}=$ concentração na saída

Os resultados dos experimentos foram submetidos à análise de comparação de média, utilizando o Software Assistat 7.7 beta (2016), comparando os atributos físicos, 
químicos e microbiológicos, entre os diferentes pontos de análise, aplicando-se o teste de Duncan a 5\% de significância. Para comparação entre os pontos de análise considerou-se como repetição os dias de coleta ( 8 coletas), já para os parâmetros $\mathrm{pH}$, CE, OD e temperatura do efluente, além da análise entre os pontos de coleta, também se comparou entre os horários de coleta $(9: 00 \mathrm{~h}, 11: 00 \mathrm{~h}$ e 13:00 h) para cada ponto, também sendo os dias de coleta as repetições. Realizou-se, também, a comparação dos resultados com as Resoluções Conama n. 357 de 2005 e a Resolução Conoma n. 430 de 2011 e com a literatura especializada.

\section{RESULTADOS E DISCUSSÃO}

\subsection{CARACTERIZAÇÃO DA VAZÃo}

A Tabela 8 apresenta a vazão de entrada nos leitos de cultivos durante o experimento nos pontos analisados entre as datas 20 de agosto a 07 de dezembro de 2015, bem como características estruturais utilizadas nos leitos cultivados e critérios de projeto.

O TDH nos leitos cultivados nos dias de análise foram em médias de 9,19 LC 1, 9,02 , 8,37 LC3 e 8,83 no LNC 4, superiores ao critério de projeto sugerido por WOOD e McATAMNEY (1996), demonstrando que a ETE/FAL/UnB possui capacidade para receber volume de esgoto bem maior, conforme projeto, pode receber volumes de esgoto de 6,5 $\mathrm{m}^{3} \mathrm{dia}^{-1}$ (Tabela 8), com exceção ao dia 06/10/15, que, devido ao vazamento de água em uma caixa de descarga dos sanitários, em que elevou o volume de água derivado à ETE o TDH foi de 2,83 dias.

Os parâmetros: Área por vazão, carga hidráulica, DBO máxima, com exceção ao dia 06/10/15, que apresentou volume de água de chegada a ETE atípico, nos demais dias e todos os leitos cultivados a ficaram dentro do critério de projeto (Tabela 8), de acordo com WOOD e McATAMNEY (1996).

O TDH elevado se deve ao fato de a ETE ter sido projetada em um período onde o número e funcionários de campo e laboratórios atendidos na FAL, especialmente no refeitório, era elevado, diminuindo progressivamente após redução do quadro de funcionários e mudanças no funcionamento do refeitório da FAL. Ao mesmo tempo, o refeitório da FAL passou a ser abastecido com água tratada pela Agência Reguladora de Águas (ADASA), transportada até o local por caminhão pipa, o que antes não acontecia, 
sendo a água utilizada captada na própria FAL. Com isso, houve controle mais rigoroso no volume de água utilizado, diminuindo, por consequência, o volume de esgoto gerado. Constata-se ainda que o volume de esgoto gerado variou muito entre os dias de análise (Tabela 8), devido especialmente ao número de estudantes que frequentam a FAL, que é variável entre os dias da semana, impactando, por exemplo, no número de refeições servidas no refeitório e no número de usuários dos sanitários.

Embora o substrato utilizado nos leitos de cultivo tenha sido a mesmo (brita n. 2), e, portanto, com mesma porosidade, para manter como variável somente a espécie de macrófita, a vazão de entrada em todos os leitos cultivados deveria ser a mesma, fato que não aconteceu. Isso porque o sistema de distribuição de água para os leitos, onde o controle era feito na própria saída da caixa de distribuição em tubos de $50 \mathrm{~mm}$, não foi eficiente, estando muito sujeito as oscilações de vazão ao longo do dia e entre os dias da semana. Nas últimas datas de coleta foram instalados vertedouros triangulares com ângulo de $80^{\circ}$ na caixa de passagem, no entanto, não houve melhora importante da equidade de distribuição de efluente entre os leitos, possivelmente por infiltrações sob os vertedouros não visíveis imediatamente, mas que, por outro lado, justifica a melhora no ajuste do sistema de distribuição do efluente, aproximando a vazão de entrada de cada leito de cultivo. 
TABELA 8. Vazão de entrada nos leitos cultivados para período de medição das 8:00 às 18:00 h, critérios de projeto, parâmetros calculados nos leitos cultivados e TDH dos tanques sépticos, para as diferentes datas de coleta no ano de 2015.

\begin{tabular}{|c|c|c|c|c|c|c|c|c|c|c|}
\hline Parâmetros calculados nos leitos & \multicolumn{10}{|c|}{ Leitos cultivados } \\
\hline \multicolumn{11}{|c|}{ LC1 } \\
\hline $\mathrm{O}\left(\mathrm{m}^{3} \mathrm{dia}^{-1}\right)$ & - & 1.38 & 0,47 & 0,36 & 0,38 & 1,35 & 0,35 & 0,39 & 0,35 & 0,37 \\
\hline Área por vazão (há $\left.\mathrm{m}^{3} . \mathrm{Dia}^{-1}\right)$ & 0,001 a 0,007 & 0,001 & 0,0035 & 0,0045 & 0,0043 & 0,0012 & 0,0046 & 0,0042 & 0,0046 & 0,0044 \\
\hline Carga Hidráulica $\left(\mathrm{mm}^{3} \mathrm{~mm}^{2} \mathrm{dia}^{-1}\right)$ & 2 a 30 & 100 & 28,92 & 22,15 & 23,38 & 83,08 & 21,54 & 24,00 & 21,54 & 22,77 \\
\hline $\mathrm{DBO}$ máxima $\left(\mathrm{kg}\right.$ há dia $\left.{ }^{-1}\right)$ & 75 & 52,5 & 60,74 & 46,52 & 49,11 & 174,46 & 45,23 & 50,40 & 45,23 & 47,82 \\
\hline Área por vazão (há $\mathrm{m}^{3}$. $\left.\mathrm{Dia}^{-1}\right)$ & 0,001 a 0,007 & 0,001 & 0,0042 & 0,0058 & 0,0044 & 0,0014 & 0,034 & 0,0033 & 0,0036 & 0,0046 \\
\hline Carga Hidráulica $\left(\mathrm{mm}^{3} \mathrm{~mm}^{2} \mathrm{dia}^{-1}\right)$ & 2 a 30 & 100 & 24,00 & 17,23 & 22,77 & 71,38 & 29,54 & 30,15 & 27,69 & 21,54 \\
\hline $\mathrm{DBO}$ máxima $\left(\mathrm{kg} \mathrm{há} \mathrm{dia}^{-1}\right)$ & 75 & 52,5 & 50,40 & 36,18 & 47,82 & 149,91 & 62,03 & 63,32 & 58,15 & 45,23 \\
\hline \multicolumn{11}{|l|}{ (2) } \\
\hline $\mathrm{Q}\left(\mathrm{m}^{3} \mathrm{dia}^{-1}\right)$ & - & 1,38 & 0,52 & 0,34 & 0,43 & 1,36 & 0,36 & 0,44 & 0,41 & 0,47 \\
\hline Tempo de Detencão Hidráulica (dias) & 2 a 7 & 2,35 & 7,34 & 11,23 & 8,88 & 2,81 & 10,61 & 8,68 & 9,31 & 8,13 \\
\hline Tempo de Detenção Hidráulica (dias) & 2 a 7 & 2,35 & 7,64 & 9,09 & 8,88 & 3,08 & 9,79 & 8,68 & 10,32 & 13,17 \\
\hline Área por vazão $\left(\right.$ há $\mathrm{m}^{3}$. $\left.\mathrm{Dia}^{-1}\right)$ & 0,001 a 0,007 & 0,001 & 0,0033 & 0,0039 & 0,0038 & 0,0013 & 0,0042 & 0,0037 & 0,0044 & 0,0056 \\
\hline Carga Hidráulica $\left(\mathrm{mm}^{3} \mathrm{~mm}^{2} \mathrm{dia}^{-1}\right)$ & 2 a 30 & 100 & 30,77 & 25,85 & 26,46 & 76,31 & 24,00 & 27,08 & 22,77 & 17,85 \\
\hline $\mathrm{DBO}$ máxima $\left(\mathrm{kg} \mathrm{há} \mathrm{dia}^{-1}\right)$ & 75 & 52,5 & 64,62 & 54,28 & 55,57 & 160,25 & 50,40 & 56,86 & 47,82 & 37,48 \\
\hline \multicolumn{11}{|c|}{ Tanques sépticos } \\
\hline
\end{tabular}

Adaptado de WOOD e McATAMNEY (1996) para leito cultivado; C.D. Valores utilizados inicialmente como critério para dimensionamento da ETE. 
A vazão de entrada, assim como a de saída dos leitos cultivados variaram bastante, o mesmo ocorre entre as datas de medição de vazão (Tabela 9). Considerando o volume total de todos os dias de medição de vazão, observa-se que na entrada dos leitos as diferenças entre os mesmos foram pequenas, o mesmo não ocorre com o volume de saída, onde se observa que não houve coerência consistente entre os volumes de entrada e saída em cada leito de cultivo, ou seja, os percentuais de diferença absoluta entre o que entrou e o que saiu não se mantiveram (Tabela 9). Fato este esta relacionada a possíveis vazamentos fundo dos leitos cultivados no início do funcionamento da ETE, mas que foram sendo obstruídos ao longo do experimento (ajustes da ETE) e também a possibilidade de ter havido escoamento preferencial em alguns dos leitos, função da formação de vácuo nas tubulações de saída de efluente, fato corrigido posteriormente pela abertura de cavidades na tubulação em pontos mais elevados, deixando o interior dos tubos na pressão efetiva.

TABELA 9. Vazão de entrada e na saída dos leitos cultivados no período da 8:00 às 18:00 h para diferentes datas do ano de 2015 para os leitos de cultivo.

\begin{tabular}{|c|c|c|c|c|c|c|c|c|}
\hline \multirow{2}{*}{$\begin{array}{l}\text { Datas de } \\
\text { Coleta }\end{array}$} & \multicolumn{4}{|c|}{$\begin{array}{c}\text { Vazão de entrada no leito } \\
\left(\mathrm{L} \mathrm{dia}^{-1}\right)\end{array}$} & \multicolumn{4}{|c|}{$\begin{array}{c}\text { Vazão de saída nos leitos } \\
\left(\mathrm{L} \mathrm{dia}^{-1}\right)\end{array}$} \\
\hline & LC 1 & LC 2 & LC 3 & LNC 4 & LC 1 & LC 2 & LC 3 & LNC 4 \\
\hline $20 / 08$ & 470 & 390 & 530 & 500 & 340 & 280 & 360 & 410 \\
\hline 08/09 & 370 & 280 & 340 & 420 & 260 & 200 & 220 & 310 \\
\hline $21 / 09$ & 380 & 370 & 430 & 430 & 330 & 260 & 320 & 310 \\
\hline $06 / 10$ & 1350 & 1160 & 1360 & 1240 & 890 & 670 & 430 & 920 \\
\hline $21 / 10$ & 350 & 480 & 360 & 390 & 270 & 320 & 170 & 340 \\
\hline $05 / 11$ & 390 & 490 & 440 & 420 & 260 & 260 & 140 & 300 \\
\hline $20 / 11$ & 350 & 450 & 410 & 370 & 270 & 250 & 250 & 280 \\
\hline $07 / 12$ & 370 & 350 & 470 & 290 & 210 & 310 & 330 & 270 \\
\hline Total & 4030 & 3970 & 4340 & 4060 & 2830 & 2550 & 2220 & 3140 \\
\hline Dif. (\%) & & & & & 42,4 & 55,7 & 95,5 & 29,3 \\
\hline
\end{tabular}

LC 1: Leito de cultivo 1 (Taboa); LC 2: Leito de cultivo 2 (Papiro-brasileiro); LC 3 Leito de cultivo (lírio do brejo) e LNC 4 Leito (não cultivado). Dif.: Diferença entre o volume de entrada e o de saída.

Deve-se destacar ainda que antes das 8:00h e após as 18:00h ainda há entrada de esgoto na ETE que não foi quantificado, e que, em função do tempo de defasagem entre a entrada e saída de efluente no sistema de tratamento, pode ter favorecido para as diferenças acentuadas de vazão. 


\subsection{AVALIAÇÕES DOS PARÂMETROS FÍSICO-QUÍMICOS E MICROBIOLÓGICOS DO EFLUENTE BRUTO, TANQUES SÉPTICOS (TS) E LEITOS CULTIVADOS (LC)}

\subsubsection{Oxigênio Dissolvido (OD)}

A Tabela 10 representa valores observados de OD durante o experimento nos pontos analisados e as eficiências do tratamento, considerando como referência P1 (efluente bruto) e P2 (saída do tanque séptico 3) para avaliar os tanques sépticos e a eficiência entre o P2 comparado aos LC1, LC2, LC3 e LNC4 para os leitos cultivados.

Em todo o período analisado, pode observar a elevação de OD em valores absolutos entre P1 (esgoto bruto) em relação a P2, com valores médios de 55,58 e 61,81 $\mathrm{mg} \mathrm{L}^{-1}$ de $\mathrm{O}_{2}$, respectivamente, e entre o $\mathrm{P} 2$ comparados aos leitos de cultivos, de 62,30, $63,62,67,21,64,48 \mathrm{mg} \mathrm{L}^{-1} \mathrm{O}_{2}$, respectivamente, para LC1, LC2, LC3 e LNC4, não apresentado diferença significativa entre os pontos analisados, considerando as datas de coleta como sendo as repetições. A inexistência de diferença estatística entre os pontos de coleta não ocorreu mesmo apresentando médias de OD entre os pontos serem elevadas, devido ao coeficiente de variação entre as datas de coleta ser muito altos, chegando a $45,89 \%$ no LNC4.

O OD é indispensável aos organismos aeróbios, sendo que na água, em condições normais, contém oxigênio dissolvido, cujo teor de saturação depende da altitude e da temperatura. Águas com baixos teores de oxigênio dissolvido indicam que receberam matéria orgânica, em que a decomposição da matéria orgânica por bactérias aeróbias é, geralmente, acompanhada pelo consumo e redução do oxigênio dissolvido da água (SOUZA et al., 2010).

Os valores de OD (Tabela 10) estão acima do valor estipulado para rios de classe II. Conforme a resolução CONAMA N N $^{\circ} 37 / 2005$ os valores de OD não devem ser inferiores a $5 \mathrm{mg} \mathrm{L}^{-1}$ (para rios de classe II), podendo concluir que os pontos analisados ainda não receberam uma quantidade elevada de matéria orgânica. 
TABELA 10. Valores médios diários de Oxigênio Dissolvido, em mg.L.-1 $\mathrm{O}_{2}$, desvio padrão, coeficiente de variação, teste de comparação de médias, considerando a entrada P1)e saída dos tanques sépticos (P2) e P2 em relação as saídas dos leitos cultivados (LC1, LC2, LC3 e LNC4) para diferentes datas de coleta

\begin{tabular}{ccccccc}
\hline \multirow{2}{*}{$\begin{array}{c}\text { Datas de } \\
\text { coleta }\end{array}$} & P1 & P2 & LC1 & LC2 & LC3 & LNC4 \\
\cline { 2 - 7 } $20 / 8$ & 41,63 & 32,73 & 33,43 & 27,33 & 30,50 & 29,73 \\
$8 / 9$ & 24,73 & 28,07 & 38,60 & 38,37 & 47,00 & 26,40 \\
$21 / 9$ & 34,23 & 48,23 & 46,47 & 60,50 & 58,67 & 40,13 \\
$6 / 10$ & 77,10 & 81,10 & 89,07 & 82,83 & 87,00 & 79,30 \\
$21 / 10$ & 41,30 & 63,03 & 48,57 & 54,13 & 60,60 & 68,60 \\
$5 / 11$ & 89,80 & 95,63 & 113,23 & 105,83 & 84,23 & 100,50 \\
$20 / 11$ & 68,10 & 55,97 & 43,77 & 56,57 & 60,20 & 70,53 \\
$7 / 12$ & 67,73 & 89,73 & 85,30 & 83,40 & 109,50 & 100,67 \\
\hline Média & 55,58 & 61,81 & 62,30 & 63,62 & 67,21 & 64,48 \\
DP & 23,13 & 25,35 & 29,32 & 25,76 & 25,05 & 29,59 \\
CV(\%) & 41,61 & 41,02 & 47,06 & 40,50 & 37,27 & 45,89 \\
p & & \multicolumn{7}{c}{0,9712} & & \\
\hline
\end{tabular}

DP: Desvio Padrão; CV (\%): Coeficiente de Variação (\%); P1: Esgoto Bruto; P2: Saída do Tanque Séptico 3; LC1: Leito de cultivo 1; LC2: Leito de cultivo 2; LC3 Leito de cultivo; LNC4 Leito de cultivo, Não houve diferença significativa entre os pontos de coleta pelo teste de Duncan a $5 \%$ de probabilidade;

Considerando os dias de coleta como sendo as repetições, se obtêm os valores de OD para os diferentes pontos de coleta, nos horários de 9:00 h, 11:00 h e 13:00 h, onde não demonstraram diferença significativa entre os tratamentos. O OD no esgoto bruto (P1), embora não significativo, em valor absoluto é menor as demais pontos avaliados na ETE (Tabela 11).

TABELA 11. Oxigênio Dissolvido em três horários de coleta para os diferentes pontos de coleta na ETE/FAL/UnB.

\begin{tabular}{ccccccc}
\hline \multirow{2}{*}{$\begin{array}{l}\text { Horário de } \\
\text { coleta }(\mathrm{h})\end{array}$} & $\mathrm{P} 1$ & $\mathrm{P} 2$ & LC1 & LC2 & LC3 & LNC4 \\
\cline { 2 - 7 } 9:00 & 45,0 & 62,4 & 50,5 & 59,7 & 48,8 & 67,0 \\
11:00 & 55,8 & 60,7 & 66,6 & 62,1 & 81,1 & 70,3 \\
13:00 & 65,9 & 62,4 & 69,8 & 69,1 & 71,7 & 56,2 \\
\hline Média & 55,6 & 61,8 & 62,3 & 63,6 & 67,2 & 64,5 \\
DP & 10,4 & 1,0 & 10,4 & 4,9 & 16,6 & 7,4 \\
CV(\%) & 18,8 & 1,6 & 16,6 & 7,7 & 24,7 & 11,4 \\
p & 0,3373 & 0,9919 & 0,5601 & 0,8239 & 0,111 & 0,7256 \\
\hline
\end{tabular}

DP : Desvio Padrão; CV (\%) : Coeficiente de Variação (\%); P1: Esgoto Bruto; P2: Saída do Tanque Séptico 3; LC1: Leito de cultivo 1; LC2: Leito de cultivo 2; LC3 Leito de cultivo; LNC4 Leito de cultivo. Não houve diferença significativa entre os horários para cada ponto de coleta de pelo teste de Duncan a $5 \%$ de probabilidade 
De maneira geral, o OD se elevou das 9:00 h para às 13:00 h, o OD é influenciado pela temperatura e por sais dissolvidos no efluente. A oxidação de compostos carbonáceos e a nitrificação dependem de sua concentração, sendo $1 \mathrm{mg} \mathrm{L}^{-1}$ o seu valor mínimo para o funcionamento dos reatores aeróbios.

\subsubsection{Condutividade Elétrica (CE)}

A Figura 10 apresenta os dados de condutividade elétrica (CE) nos pontos de coletas analisados para diferentes dias. A CE, de modo geral, mais elevada em nos leitos de cultivos em valor absoluto, embora estatisticamente forem iguais, com valores médios de 908,78; 956,08; 975,21 e 965,88 $\mu \mathrm{S} \mathrm{cm}^{-1}$, para LC1, LC2, LC3 e LNC4, respectivamente. O P1 com média de $619,92 \mu \mathrm{S} \mathrm{cm}^{-1}$ foi menor que o P2 com valor de $904,33 \mu \mathrm{S} \mathrm{cm}^{-1}$ e próximo aos valores de LC na saída dos leitos. O elevado valor de CE no P2 e nos LC é devido à oxidação da matéria orgânica liberando uma maior quantidade de íons dissolvidos na água.

A CE é uma expressão numérica da capacidade de uma água conduzir a corrente elétrica. Este parâmetro está relacionado com a presença de íons dissolvidos na água, que são partículas carregadas eletricamente. Quanto maior for à quantidade de íons dissolvidos, maior será a condutividade elétrica na água (SOUZA et al., 2010).

Depende das concentrações iônicas e da temperatura e indica a quantidade de sais existentes na columa d'água, portanto, representa uma medida indireta da concentração de poluentes. Em geral, níveis superiores a $100 \mu \mathrm{S} \mathrm{cm}^{-1}$ indicam ambiente impactados (PINTO et al., 2010).

A CE também fornece uma boa indicação das modificações na composição de uma água, especialmente na sua concentração mineral, mas não fornece nenhuma indicação das quantidades relativas dos vários componentes. À medida que mais sólidos dissolvidos são adicionados, a CE da água aumenta. Altos valores podem indicar características corrosivas da água (CETESB, 2008). 


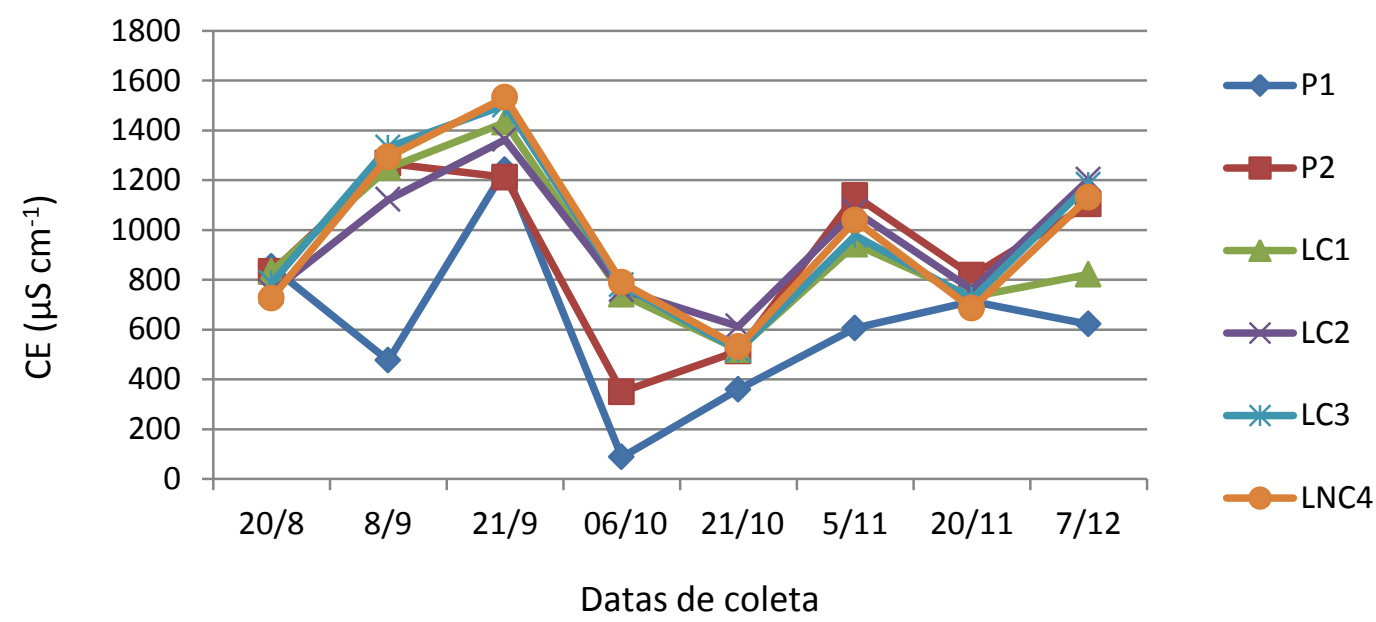

FIGURA 10. Valores de Condutividade Elétrica, em $\mu \mathrm{S} \mathrm{cm}^{-1}$ em diferentes datas de coleta para diferentes pontos avaliados na ETE.

O elevado valor de CE no P2 e nos LC é devido à oxidação da matéria orgânica, liberando uma maior quantidade de íons dissolvidos na água.

Em todos os pontos de coleta avaliados, a CE reduziu das 9:00 h para às 13:00 h, ao mesmo tempo, no esgoto bruto (P1) foi inferior, em valor absoluto, em relação aos demais pontos, porém, na saída dos leitos foi diferente da entrada dos mesmos, embora com valores muito próximos (Figura 11). No LC1 a CE foi inferior aos demais leitos em todos os horários avaliados, que pode estar relacionado ao possível efeito na redução na concentração de sais pela absorção pelas plantas de Taboa, que demonstrou melhor desenvolvimento inicial em relação ás outras espécies de macrófitas.

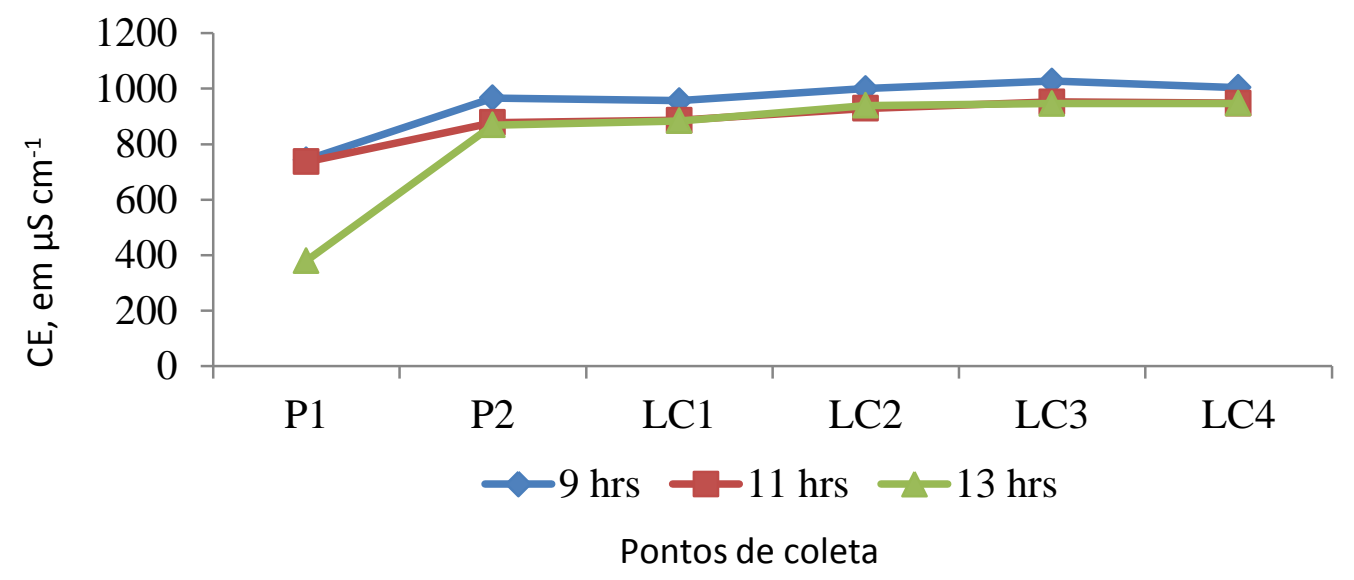

FIGURA 11. Valores de Condutividade Elétrica, em $\mu \mathrm{S} \mathrm{cm}^{-1}$, em diferentes pontos de coletas em diferentes horários de coleta. 


\section{2. 3 Temperatura do efluente}

A temperatura do efluente nos leitos de cultivo foi medida no momento das coletas e poucas variações foram observadas, permanecendo a média de $30{ }^{\circ} \mathrm{C}$ (Tabela 12).

Os valores da temperatura determinados antes dos tanques sépticos e após passar pelos leitos cultivados não variaram de maneira significativa, ficando em torno $30^{\circ} \mathrm{C}$, porém em todo o período analisado, pode observar uma pequena diferença de temperatura, em valores absolutos, entre o P1 (esgoto bruto) e os valores da saída dos leitos de cultivos, estes foram menores que os de entrada, isso ocorre possivelmente porque no leito cultivado, o efluente está mais exposto à radiação solar. O mesmo ocorreu no trabalho realizado por ASSUMPÇÃO et al. (2011) ao avaliar o desempenho do leito cultivado de uma estação de tratamento de efluentes gerado em uma instituição de ensino após período de inatividade.

TABELA 12. Dados de Temperatura em ${ }^{\circ} \mathrm{C}$, desvio padrão, coeficiente de variação, teste de comparação de médias verificados entre a entrada e saída dos tanques sépticos (P1 e P2) e na entrada e saída dos leitos cultivados (P2 em relação a LC1, LC2, LC3 e LNC4).

\begin{tabular}{ccccccc}
\hline \multirow{2}{*}{$\begin{array}{c}\text { Datas } \\
\text { coleta }\end{array}$} & P1 & P2 & LC1 & LC2 & LC3 & LNC4 \\
\cline { 2 - 6 } $20 / 8$ & 32,67 & 31,53 & 31,90 & 32,03 & 29,83 & 30,20 \\
$8 / 9$ & 31,27 & 28,90 & 25,67 & 26,47 & 28,10 & 27,80 \\
$21 / 9$ & 32,70 & 30,57 & 31,53 & 31,47 & 30,87 & 30,87 \\
$6 / 10$ & 30,23 & 31,20 & 29,00 & 30,27 & 30,07 & 29,53 \\
$21 / 10$ & 31,17 & 31,30 & 32,37 & 33,77 & 34,40 & 31,87 \\
$5 / 11$ & 28,60 & 29,00 & 28,93 & 30,17 & 29,63 & 30,07 \\
$20 / 11$ & 28,30 & 28,90 & 27,67 & 28,63 & 27,93 & 30,73 \\
$7 / 12$ & 28,50 & 28,63 & 30,53 & 28,63 & 29,70 & 30,17 \\
\hline Média & 30,43 & 30,00 & 29,70 & 30,18 & 30,07 & 30,15 \\
DP & 1,81 & 1,26 & 2,31 & 2,28 & 2,01 & 1,18 \\
CV(\%) & 5,96 & 4,20 & 7,79 & 7,57 & 6,68 & 3,91 \\
p & & & \multicolumn{7}{c}{0,9841} & & \\
\hline
\end{tabular}

DP: Desvio Padrão; CV (\%): Coeficiente de Variação (\%); P1: Esgoto Bruto; P2: Saída do Tanque Séptico 3; LC1: Leito de cultivo 1; LC2: Leito de cultivo 2; LC3 Leito de cultivo; LNC4 Leito de cultivo, Não houve diferença significativa entre os pontos de coleta pelo teste de Duncan a 5\% de probabilidade.

A variação da temperatura do esgoto no leito cultivado, por ser uma fase aberta, é influenciada pelas mudanças climáticas que ocorrem no ambiente. Os valores descritos na literatura tendem a variar de acordo com o local de estudo e a época do ano (TONIATO, 2005). 
Entre os leitos, o cultivado com taboa (leito 4), apresentou temperaturas menores, em valores absolutos, em relação aos demais leitos, decorrente do maior desenvolvimento e cobertura dos leitos.

A Tabela 13 representa a variação da temperatura nos três horários de coleta das amostras, para os diferentes pontos de coleta, considerando os dias como sendo as repetições.

TABELA 13. Dados de temperatura, em ${ }^{\circ} \mathrm{C}$, desvio padrão, coeficiente de variação, verificados entre o efluente bruto $(\mathrm{P} 1)$ e saída dos tanques sépticos (P2) e entrada e saída dos leitos cultivados (LC1, LC2, LC3 e LNC4) para diferentes horários de coleta.

\begin{tabular}{|c|c|c|c|c|c|c|}
\hline \multirow{2}{*}{$\begin{array}{l}\text { Horário de } \\
\text { coleta (h) }\end{array}$} & \multicolumn{6}{|c|}{ Pontos de coleta } \\
\hline & $\mathrm{P} 1$ & $\mathrm{P} 2$ & LC1 & LC2 & LC3 & LNC4 \\
\hline $9: 00$ & $29,04 \mathrm{~b}$ & $28,40 \mathrm{~b}$ & $29,84 \mathrm{a}$ & $29,41 \mathrm{a}$ & $29,24 \mathrm{a}$ & $29,28 \mathrm{a}$ \\
\hline $11: 00$ & $29,34 \mathrm{~b}$ & $29,20 \mathrm{a}$ & $28,58 \mathrm{a}$ & $29,39 \mathrm{a}$ & $30,23 \mathrm{a}$ & $29,46 \mathrm{a}$ \\
\hline $13: 00$ & $32,91 \mathrm{a}$ & $32,41 \mathrm{a}$ & $30,69 \mathrm{a}$ & $31,74 \mathrm{a}$ & $30,74 \mathrm{a}$ & $31,73 \mathrm{a}$ \\
\hline Média & 30,4 & 30,0 & 29,7 & 30,2 & 30,1 & 30,2 \\
\hline DP & 2,2 & 2,1 & 1,1 & 1,3 & 0,8 & 1,4 \\
\hline $\mathrm{CV}(\%)$ & 7,1 & 7,1 & 3,6 & 4,5 & 2,5 & 4,5 \\
\hline $\mathrm{p}$ & 0,012 & 0,006 & 0,408 & 0,256 & 0,706 & 0,177 \\
\hline
\end{tabular}

DP: Desvio Padrão; CV (\%): Coeficiente de Variação (\%); P1: Esgoto Bruto; P2: Saída do Tanque Séptico 3; LC1: Leito de cultivo 1; LC2: Leito de cultivo 2; LC3 Leito de cultivo; LNC4 Leito de cultivo. Letras diferentes entre os horários de coleta para cada ponto de coleta diferem pelo teste de Duncan a 5\% de probabilidade.

Nos pontos P1 e P2, a temperatura às 13:00 h foi maior que nos horários das 9:00 e 11:00 h, devido ao aquecimento do efluente promovido pela radiação solar. A temperatura do efluente apresentou pouca variação entre as datas de coleta, motivo pelo qual o desvio padrão foi baixo, ao contrário da maioria dos demais parâmetros analisados neste trabalho. Observa-se ainda que às 13:00 h a temperatura foi maior em relação às 9:00 h e 11:00 h no P2.

\section{2. 4 Potencial Hidrogeniônico (pH)}

$\mathrm{O}$ valor de $\mathrm{pH}$ no esgoto bruto (P1) variou de 5,40 a 7,13 com média 6,67 (Tabela 14), no $\mathrm{P} 2$, observou-se diminuição de $\mathrm{pH}$, com valor médio de 5,70 à medida que o esgoto passava pelos tanques sépticos (P2). Este fato deve-se às bactérias formadoras de ácidos que fracionam a matéria orgânica e produzir ácidos voláteis (Von Sperling, 2005), resultando num aumento da acidez do meio, reduzindo o $\mathrm{pH}$. 
Os valores médios foram de 7,42; 7,42 e 7,20 para o LC1, LC2, LC3, respectivamente, sendo significativamente maiores aos demais pontos avaliados. No LNC4, sem cultivo, apresentou um valor 6,66 de $\mathrm{pH}$, também dentro da faixa de neutralidade, porém, na saída do TS 3, o pH foi menor em relação a todos os demais pontos. Mansor (1998) relatou a mesma observação, onde o sistema de leito cultivado foi utilizado no pós-tratamento de efluente de esgoto doméstico tratado por tanque séptico modificado.

$\mathrm{O} \mathrm{pH}$ em valor absoluto entre a entrada e saídas dos tanques sépticos não se elevou, o mesmo não ocorreu nos leitos cultivados, que na saída o efluente foi maior que na entrada. Assim sendo, o sistema operou com valores compatíveis com os recomendados e observados em experimento realizado por outros autores, como COLARES e SANDRI (2013), que realizou um tratamento de esgoto de uma unidade universitária com tanques sépticos seguidos de leitos cultivados com diferentes meios de suporte; constatou ainda, valores de $\mathrm{pH}$ compreendidos na faixa de neutralidade

$\mathrm{O}$ pH representa a concentração de íons hidrogênio $\mathrm{H}^{+}$, dando uma indicação sobre a condição de acidez, neutralidade ou alcalinidade da água. O levantamento desse parâmetro é importante para o controle dos processos de tratamento de águas residuárias. Valores de $\mathrm{pH}$ afastados da neutralidade podem afetar o crescimento de microrganismos. Segundo Foresti (1998), o pH ótimo para a digestão anaeróbia é de 6,8 a 7,5, mas o processo ainda continua bem sucedido num limite de 6,0 a 8,0.

TABELA 14. Valores de $\mathrm{pH}$, desvio padrão, coeficiente de variação, teste de comparação de médias entre a entrada $(\mathrm{P} 1)$ e saída dos tanques sépticos $(\mathrm{P} 2)$ e entre a entrada (P2) e saída dos leitos cultivados (LC1, LC2, LC3 e LNC4) para diferentes datas de coleta.

\begin{tabular}{ccccccc}
\hline Datas & \multicolumn{7}{c}{ Pontos de coleta } \\
\cline { 2 - 7 } coleta & P1 & P2 & LC1 & LC2 & LC3 & LNC4 \\
\hline $20 / 8$ & 5,40 & 5,57 & 7,10 & 7,33 & 7,17 & 6,60 \\
$8 / 9$ & 6,30 & 5,67 & 7,70 & 7,73 & 7,47 & 6,97 \\
$21 / 9$ & 6,93 & 6,03 & 7,53 & 7,50 & 7,27 & 6,73 \\
$6 / 10$ & 7,07 & 5,73 & 7,47 & 7,50 & 7,23 & 6,80 \\
$21 / 10$ & 6,67 & 5,67 & 7,23 & 7,13 & 7,00 & 5,87 \\
$5 / 11$ & 6,77 & 5,47 & 7,53 & 7,47 & 6,93 & 6,73 \\
$20 / 11$ & 7,07 & 6,10 & 7,47 & 7,40 & 7,37 & 7,07 \\
$7 / 12$ & 7,13 & 5,37 & 7,33 & 7,27 & 7,20 & 6,50 \\
\hline Média & $6,67 \mathrm{~b}$ & $5,70 \mathrm{c}$ & $7,42 \mathrm{a}$ & $7,42 \mathrm{a}$ & $7,20 \mathrm{a}$ & $6,66 \mathrm{~b}$ \\
DP & 0,58 & 0,26 & 0,19 & 0,18 & 0,18 & 0,37 \\
CV(\%) & 8,71 & 4,49 & 2,56 & 2,43 & 2,44 & 5,53 \\
p & & \multicolumn{7}{c}{$<0,0001$} & & \\
\hline
\end{tabular}


DP: Desvio Padrão; CV (\%): Coeficiente de Variação (\%); P1: Esgoto Bruto; P2: Saída do Tanque Séptico 3; LC1: Leito de cultivo 1; LC2: Leito de cultivo 2; LC3 Leito de cultivo; LNC4 Leito de cultivo, Médias seguidas por letra iguais na linha nãodiferem entre si pelo teste de Duncan a $5 \%$ de probabilidade;

Os valores médios de pH para os horários de coleta de 9:00 h, 11:00 h e 13:00 h nos diferentes pontos de coleta, média, desvio padrão, coeficiente de variação, teste de comparação de médias e eficiência do sistema nos pontos analisados são mostrados na Tabela 15. Nos leitos cultivados e sem cultivo, de modo geral, apresentou média de temperatura mais alta que no P1 (efluente bruto) e em P2. Também demonstrou uma tendência a aumentar a temperatura das 9:00 h às 13:00 h.

TABELA 15. Valores de $\mathrm{pH}$, desvio padrão, coeficiente de variação, teste de comparação de médias entre o esgoto bruto (P1) e saída dos tanques sépticos $(\mathrm{P} 2)$ e na entrada (P2) e saída dos leitos cultivados (LC1, LC2, LC3 e LNC4) para diferentes horários de coleta.

\begin{tabular}{ccccccc}
\hline \multirow{2}{*}{$\begin{array}{c}\text { Horário de } \\
\text { coleta }(\mathrm{h})\end{array}$} & P1 & P2 & LC1 & LC2 & LC3 & LNC4 \\
\cline { 2 - 7 } 9:00 & $6,38 \mathrm{a}$ & $5,71 \mathrm{a}$ & $7,45 \mathrm{a}$ & $7,45 \mathrm{a}$ & $7,00 \mathrm{~b}$ & $6,51 \mathrm{a}$ \\
$11: 00$ & $6,60 \mathrm{a}$ & $5,69 \mathrm{a}$ & $7,38 \mathrm{a}$ & $7,38 \mathrm{a}$ & $7,28 \mathrm{ab}$ & $6,71 \mathrm{a}$ \\
$13: 00$ & $7,03 \mathrm{a}$ & $5,70 \mathrm{a}$ & $7,44 \mathrm{a}$ & $7,43 \mathrm{a}$ & $7,34 \mathrm{a}$ & $6,75 \mathrm{a}$ \\
\hline Média & 6,7 & 5,7 & 7,4 & 7,4 & 7,2 & 6,7 \\
DP & 0,3 & 0,0 & 0,0 & 0,0 & 0,2 & 0,1 \\
CV(\%) & 5,0 & 0,2 & 0,5 & 0,5 & 2,5 & 1,9 \\
p & 0,2986 & 0,99 & 0,7717 & 0,7574 & 0,0596 & 0,5575 \\
\hline
\end{tabular}

DP: Desvio Padrão; CV (\%): Coeficiente de Variação (\%); P1: Esgoto Bruto; P2: Saída do Tanque Séptico 3; LC1: Leito de cultivo 1; LC2: Leito de cultivo 2; LC3 Leito de cultivo; LNC4 Leito de cultivo. Letras iguais entre os horários de coleta para cada ponto de avaliado não diferem pelo teste de Duncan a $5 \%$ de probabilidade.

$\mathrm{O}$ pH em P1, P2 e nos leitos de cultivos estão dentro do estabelecido pela legislação vigente (Resolução CONAMA, No 430/2011), que indica um pH de 5,0 a 9,0 para o padrão de lançamento de efluente tratado diretamente ao corpo receptor de classe II.

\subsubsection{Turbidez}

A Figura 12 mostra os valores médios de turbidez em NTU. No P1, o valor médio da turbidez variou entre 77 a 552 NTU, sendo significativamente mais altos que aos demais pontos avaliados, o mesmo ocorre com o ponto P2 (saídas dos tanques sépticos), também, a turbidez nas saídas dos leitos são menores a entrada dos mesmos, demonstrando a excelente capacidade de remoção de sólidos do sistema, colaborados 
pelo elevado TDH. Porém observa-se a gradativa diminuição da turbidez, com médias de 206,88 NTU (P2) para os leitos de cultivos: 13,17 NTU (LC1), 17,60 NTU (LC2), 12,05 NTU (LC3) e 17,04 NTU (LNC4).

Cunha (2006) afirma que, nos leitos cultivados, a remoção da turbidez ocorre por meio de processos de filtragem, sedimentação, assimilação pelas plantas e metabolismo microbiano da matéria residual suspensa e coloidal, fatores que levaram a redução de turbidez neste trabalho.

A turbidez indica o estado em que o esgoto se encontra, relacionado com a concentração dos sólidos em suspensão. Esgotos mais frescos ou mais concentrados possuem geralmente maior turbidez (Von SPERLING, 2005).

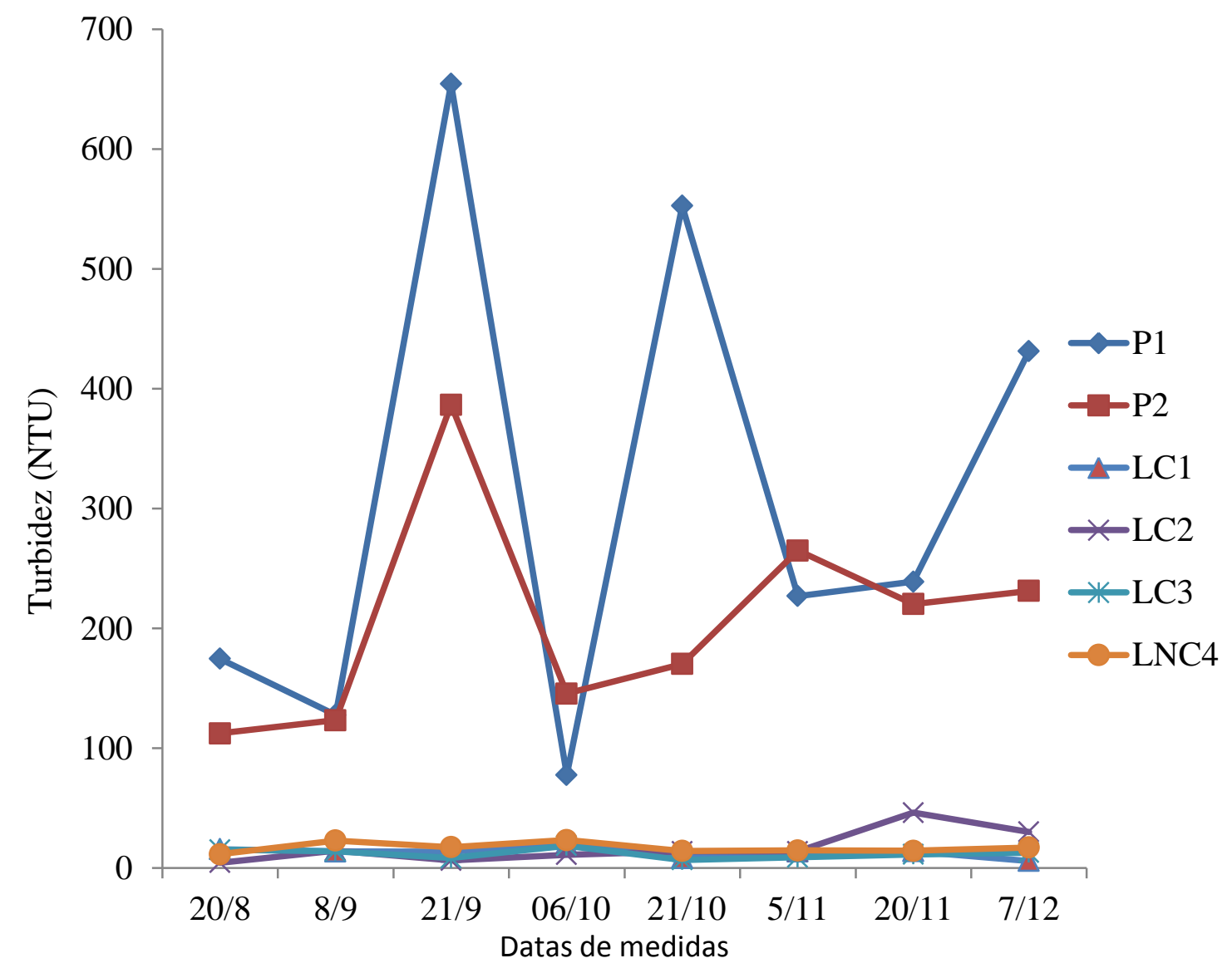

FIGURA 12. Valores médio de turbidez (NTU) para os P1, P2, LC1, LC2,LC3 e LNC4, entre o dia 20 de agosto á 07 de dezembro de 2015.

A eficiência de remoção média entre os pontos P1 e P2 (E.T.S.), e entre P2 em relação a LC1, LC2, LC3 e LNC4, foram 12,4\%, 92,3\%, 90,9\%, 92,7\% e 90,3\%, respectivamente (Tabela 16). 
TABELA 16. Eficiência total diminuição na concentração de turbidez em NTU, desvio padrão, coeficiente de variação, teste de comparação de médias entre a entrada (P1) e saída dos tanques sépticos (P2) e entre a entrada (P2) e saída dos leitos cultivados (LC1, LC2, LC3 e LNC4) para diferentes datas de coleta.

\begin{tabular}{cccccc}
\hline & \multicolumn{5}{c}{ Eficiências (\%) } \\
\cline { 2 - 6 } Datas coleta & E.T.S. & LC1 & LC2 & LC3 & LNC4 \\
\hline $20 / 8$ & 35,7 & 86,0 & 95,9 & 86,4 & 89,7 \\
$8 / 9$ & 3,4 & 88,8 & 88,2 & 88,6 & 81,4 \\
$21 / 9$ & 40,9 & 96,5 & 98,3 & 97,8 & 95,5 \\
$6 / 10$ & $-87,6$ & 86,2 & 92,4 & 87,2 & 83,9 \\
$21 / 10$ & 69,2 & 95,1 & 91,9 & 96,0 & 91,6 \\
$5 / 11$ & $-16,7$ & 94,8 & 94,8 & 96,6 & 94,4 \\
$20 / 11$ & 7,8 & 93,7 & 79,0 & 94,8 & 93,5 \\
$7 / 12$ & 46,4 & 97,4 & 87,0 & 94,4 & 92,5 \\
\hline Média & 12,4 & 92,3 & 90,9 & 92,7 & 90,3 \\
DP & 48,8 & 4,6 & 6,1 & 4,6 & 5,1 \\
CV(\%) & 394,2 & 5,0 & 6,7 & 4,9 & 5,6 \\
p & - & \multicolumn{3}{c}{$<0,4092$} \\
\hline DP: Den
\end{tabular}

DP: Desvio Padrão; CV (\%): Coeficiente de Variação (\%); P1: Esgoto Bruto; P2: Saída do Tanque Séptico 3; LC1: Leito de cultivo 1; LC2: Leito de cultivo 2; LC3 Leito de cultivo; LNC4 Leito de cultivo; E.T.S. Eficiência dos tanques sépticos (P1 a P2).

Médias seguidas por letra iguais na linha nãodiferem entre si pelo teste de Duncan a 5\% de probabilidade

A turbidez de efluentes dos E.T.S. é caracterizada por valores altos, relacionada aos sólidos suspensos presentes no esgoto bruto. Valores próximos a estes foram encontrados por VALENTIM (1999), que projetou, construiu e avaliou durante os primeiros seis meses de funcionamento um sistema composto por um tanque séptico modificado (TSM), seguido por leitos cultivados de vazão subsuperficial na forma retangular e quadrada. O tanque séptico modificado de três compartimentos em série obteve redução turbidez entre $67 \%$ e $92 \%$.

\subsubsection{Alcalinidade}

A alcalinidade foi visivelmente maior na saída dos leitos cultivados em relação aos pontos do efluente bruto, com valor médio de $77,13 \mathrm{mg} \mathrm{L}^{-1}$ e saída do tanque séptico (P2) de 160,90 mg L $\mathrm{m}^{-1}$ de $\mathrm{CaCO}_{3}$, já na saída dos leitos chegou a 361,50; 390,0; 380,40; 396,90 mg L $\mathrm{m}^{-1}$ de $\mathrm{CaCO}_{3}$, nos LC1, LC2, LC3, LNC4, respectivamente, mais que o dobro da entrada, porém, tanto entre os dias como entre os pontos de coleta houve bastante variação (Figura 13), similar aos valores observados por CUNHA (2012) (411,2 mg L ${ }^{-1}$ de $\mathrm{CaCO}_{3}$ ). 
Alcalinidade é um parâmetro importante em ETE, pois diz respeito à capacidade da solução em neutralizar íons $\mathrm{H}^{+}$, no tratamento de esgotos, quando há evidências de que a redução do $\mathrm{pH}$ pode afetar os microrganismos responsáveis pela depuração. Os principais constituintes são os bicarbonatos $\left(\mathrm{HCO}_{3^{-}}\right)$, os carbonatos $\left(\mathrm{CO}_{3}{ }^{-}\right)$e os hidróxidos $\left(\mathrm{OH}^{-}\right)$. A alcalinidade não tem significado sanitário para a água potável, mas em elevadas concentrações, confere um gosto “amargo" à água. É uma determinação importante no controle do tratamento da água, estando relacionada com a coagulação, redução de dureza e prevenção da corrosão em tubulações e conexões metálicas.

Segundo Chernicharo (2007) a interação da alcalinidade com os ácidos voláteis durante a digestão anaeróbia fundamenta-se na capacidade da alcalinidade do sistema em neutralizar os ácidos formados no processo e também o $\mathrm{pH}$ na eventualidade de sua acumulação. No monitoramento de reatores anaeróbios, a verificação sistemática da alcalinidade torna-se mais importante que a avaliação do $\mathrm{pH}$, onde o abaixamento deste, diminui a capacidade de tamponamento.

Observou-se valores significativos de alcalinidade média nos P1 e P2, isso se deve a oscilação do tipo efluente gerado no dia da coleta, resultando em desvio padrão maior que nos leitos cultivados (Figura 13). A biomassa presente nos tanques sépticos está em equilíbrio, favorecendo os processos de digestão anaeróbia, evitando choques orgânicos e possibilitando a manutenção do efeito de tamponamento e permitindo condições adequadas à granulação e floculação da biomassa bacteriana.

Para o LC1, LC2, LC3 e LNC4 não houve diferença significativa na avaliação da alcalinidade, onde ocorreu o aumento nos quatros pontos em relação à entrada dos leitos. Sendo a alcalinidade é devida a presença de sais de ácido carbônico, carbonatos, bicarbonatos e hidróxidos, a soma da alcalinidade produzida por estes íons confere a 
alcalinidade

total.

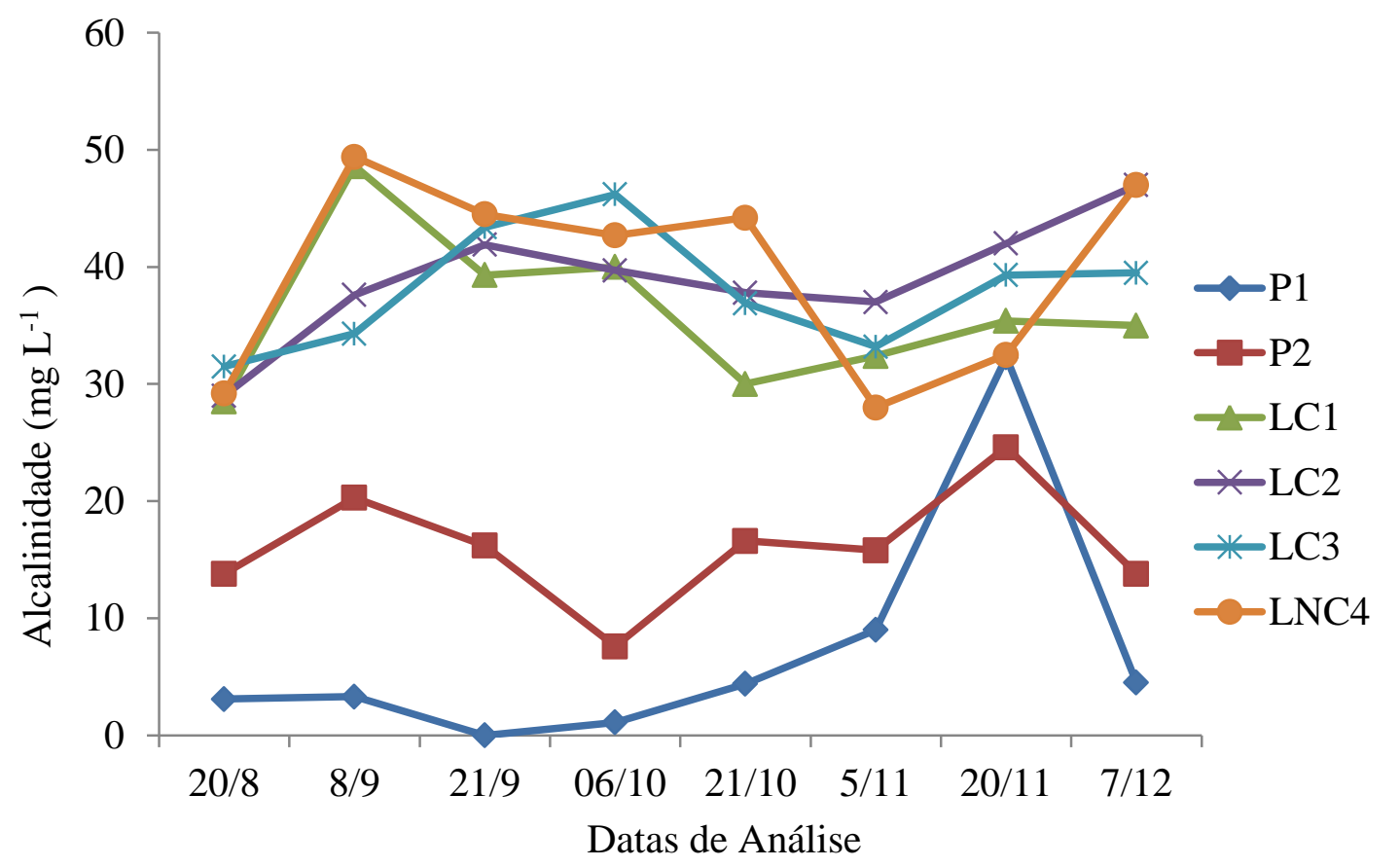

FIGURA 13. Valores de Alcalinidade total, em mg L ${ }^{-1}$, entre o dia 20 de agosto á 07 de dezembro de 2015 para diferentes pontos de análises.

\subsubsection{Sólidos suspensos totais (SST)}

Sólidos suspensos totais (SST), por definição, são todos os sólidos sedimentáveis e flutuantes presentes no efluente. Na prática, os sólidos suspensos são aqueles passíveis de serem retidos por filtração em membrana específica e posteriormente secos até peso constante. Na Tabela 17, observas-se que os SST no P1 varia de $96 \mathrm{mg} \mathrm{L}^{-1}$ a $1507 \mathrm{mg} \mathrm{L}^{-1}$, com média de $453 \mathrm{mg} \mathrm{L}^{-1}$ e em P2 com média de 235,62 $\mathrm{mg} \mathrm{L}^{-1}$, mostrando que os tanques sépticos foram eficiente na remoção de SST. Porém, na primeira data de coleta, os SST foram maiores após tanques sépticos, já que a ETE havia entrado em operação a poucos dias, o que resultou em elevada carga de SST na massa esgoto no interior dos tanques, sendo careados pelo fluxo de efluente. Porém, com processo de estabilização do processo de decomposição, as remoções de sólidos passaram a ser mais eficientes.

De acordo com Vymazal et al. (1998) e Valentim (2003) os sistemas de leitos cultivados de fluxo subsuperficial apresentam uma boa capacidade de remoção de sólidos suspensos totais. Tal afirmativa pode ser observada no presente estudo, onde os valores médios foram LC1, LC2, LC3 e LNC4 foram de 118,37 $\mathrm{mg} \mathrm{L}^{-1}, 135,25 \mathrm{mg} \mathrm{L}^{-1}$, $94,38 \mathrm{mg} \mathrm{L}^{-1}$ e $114,12 \mathrm{mg} \mathrm{L}^{-1}$ de SST,com eficiência médias de 58,6\%, 55,8\%, 70,4\%, e 
$63,0 \%$, respectivamente, superiores aos determinados pela legislação. Segundo a Resolução do CONAMA nº 430 (BRASIL, 2011), os sólidos em suspensão totais deve ter eficiência mínima de remoção de $20 \%$ para lançamento em corpos receptores.

O P2 e LC'S apresentou pouca variação de SST entre as datas de coleta, motivo pelo qual o desvio padrão foi muito baixo ao comparado com P1, não apresentando diferença significativa na avaliação de SST. Um dos motivos da elevada concentração de SST entre as datas de coleta se deve ás mudanças bruscas de vazão de esgoto ao longo do dia, fazendo com que houve turbulência e movimentação dos sólidos em ocasiões de vazões mais elevadas. Esse fato ficou muito evidente na data de 5/11, já que neste dia houve vazamento de água em um dos sanitários.

TABELA 17. Valores de sólidos suspensos, em $\mathrm{mg} \mathrm{L}^{-1}$, desvio padrão, coeficiente de variação, teste de comparação de médias entre a entrada (P1) e saída dos tanques sépticos (P2) e entre a entrada (P2) e saída dos leitos cultivados (LC1, LC2, LC3 e LNC4), para diferentes datas de coleta.

\begin{tabular}{|c|c|c|c|c|c|c|c|c|c|c|c|}
\hline \multirow{2}{*}{$\begin{array}{c}\text { Datas } \\
\text { de } \\
\text { coleta }\end{array}$} & \multicolumn{6}{|c|}{ Pontos de coleta } & \multicolumn{5}{|c|}{ Eficiências (\%) } \\
\hline & $\mathrm{P} 1$ & $\mathrm{P} 2$ & $\mathrm{LC} 1$ & $\mathrm{LC} 2$ & LC3 & LNC4 & E.T.S. & LC1 & $\mathrm{LC} 2$ & LC3 & LNC4 \\
\hline $20 / 8$ & 172 & 262 & 413 & 359 & 211 & 169 & $-52,3$ & $-57,6$ & $-37,0$ & 19,5 & 35,5 \\
\hline $4 / 9$ & 220 & 122 & 62 & 37 & 42 & 50 & 44,5 & 49,2 & 69,7 & 65,6 & 59,0 \\
\hline $21 / 9$ & 485 & 190 & 25 & 12 & 28 & 38 & 60,8 & 86,8 & 93,7 & 85,3 & 80,0 \\
\hline $6 / 10$ & 96 & 127 & 55 & 30 & 45 & 51 & $-32,3$ & 56,7 & 76,4 & 64,6 & 59,8 \\
\hline $21 / 10$ & 338 & 142 & 10 & 59 & 4 & 31 & 58,0 & 93,0 & 58,5 & 97,2 & 78,2 \\
\hline $5 / 11$ & 1507 & 733 & 368 & 518 & 404 & 515 & 51,4 & 49,8 & 29,3 & 44,9 & 29,7 \\
\hline $20 / 11$ & 356 & 152 & 12 & 52 & 19 & 31 & 57,3 & 92,1 & 65,8 & 87,5 & 79,6 \\
\hline $7 / 12$ & 450 & 157 & 2 & 15 & 2 & 28 & 65,1 & 98,7 & 90,4 & 98,7 & 82,2 \\
\hline Média & $\begin{array}{c}453,00 \\
\mathrm{a}\end{array}$ & $\begin{array}{c}235,62 \\
a b\end{array}$ & $\begin{array}{c}118,37 \\
\text { b }\end{array}$ & $\begin{array}{c}135,25 \\
\text { b }\end{array}$ & $\begin{array}{c}94,38 \\
\text { b }\end{array}$ & $\begin{array}{c}114,12 \\
\text { b }\end{array}$ & 31,6 & 58,6 & 55,8 & 70,4 & 63,0 \\
\hline $\mathrm{DP}$ & 446,46 & 205,92 & 169,72 & 192,61 & 142, & & & 51,3 & 42,6 & 27,6 & 20,9 \\
\hline $\mathrm{CV}(\%)$ & 98,56 & 87,39 & 143,37 & 142,41 & 150,62 & 147,68 & 146,7 & 87,5 & 76,2 & 39,2 & 33,1 \\
\hline $\mathrm{p}$ & & & 0,0 & 426 & & & & & & & \\
\hline
\end{tabular}

DP: Desvio Padrão, em mg L ${ }^{-1}$; CV: Coeficiente de variação (\%); P1: Esgoto bruto; P2: Saída do tanque séptico 3; LC1: Leito de cultivo 1 (Taboa); LC2: Leito de cultivo 2 (Papiro brasileiro); LC3: Leito de cultivo 3 (Lírio do brejo); LNC4: Leito de cultivo 4 (sem planta); E.T.S. Eficiência dos tanques sépticos (P1 a P2).

Médias seguidas por letras iguais na linha não diferem entre si pelo teste de Duncan a $5 \%$ de probabilidade.

As eficiências médias de remoção de SST para E.T.S foi de 31,6 \%, compatível com trabalho realisado por COLARES e SANDRI (2013) que obteve valores de SST 
para TSC1 (brita n. 2), TSC2 (cascalho lavado) e TSC3 (cascalho natural) de 30,24\%; $43,19 \%$ e $54,31 \%$, cultivados com taboa, respectivamente.

\subsection{Sólidos Totais (ST)}

Os sólidos totais estão presentes no esgoto como a matéria sólida que permanece como resíduo após a evaporação a uma determinada temperatura. A Figura 14 apresenta os valores de ST nas diversas datas e pontos de coleta, onde observa-se grande variabilidade. Tal fato pode ser atribuído à flutuação populacional da FAL/UnB, bem como a variação do nível do efluente gerado no dia da coleta. Isso pode ser comprovado, observando o P1, que teve a maior variabilidade de ST entre os dias de coletas, com desvio padrão de $511 \mathrm{mg} \mathrm{L}^{-1}$ e uma média de $995 \mathrm{mg} \mathrm{L}^{-1}$, bem superior o P2 e os LC, isso de deve ao fato de ser fluente bruto. Sperling (2005) especifica a faixa de 700,0 mg L $\mathrm{m}^{-1}$ a $1350 \mathrm{mg} \mathrm{L}^{-1}$ para ST no esgoto bruto e sendo JORDÃO e PESSOA (2009) entre $370,0 \mathrm{mg} \mathrm{L}^{-1}$ a $1170 \mathrm{mg} \mathrm{L}^{-1}$.

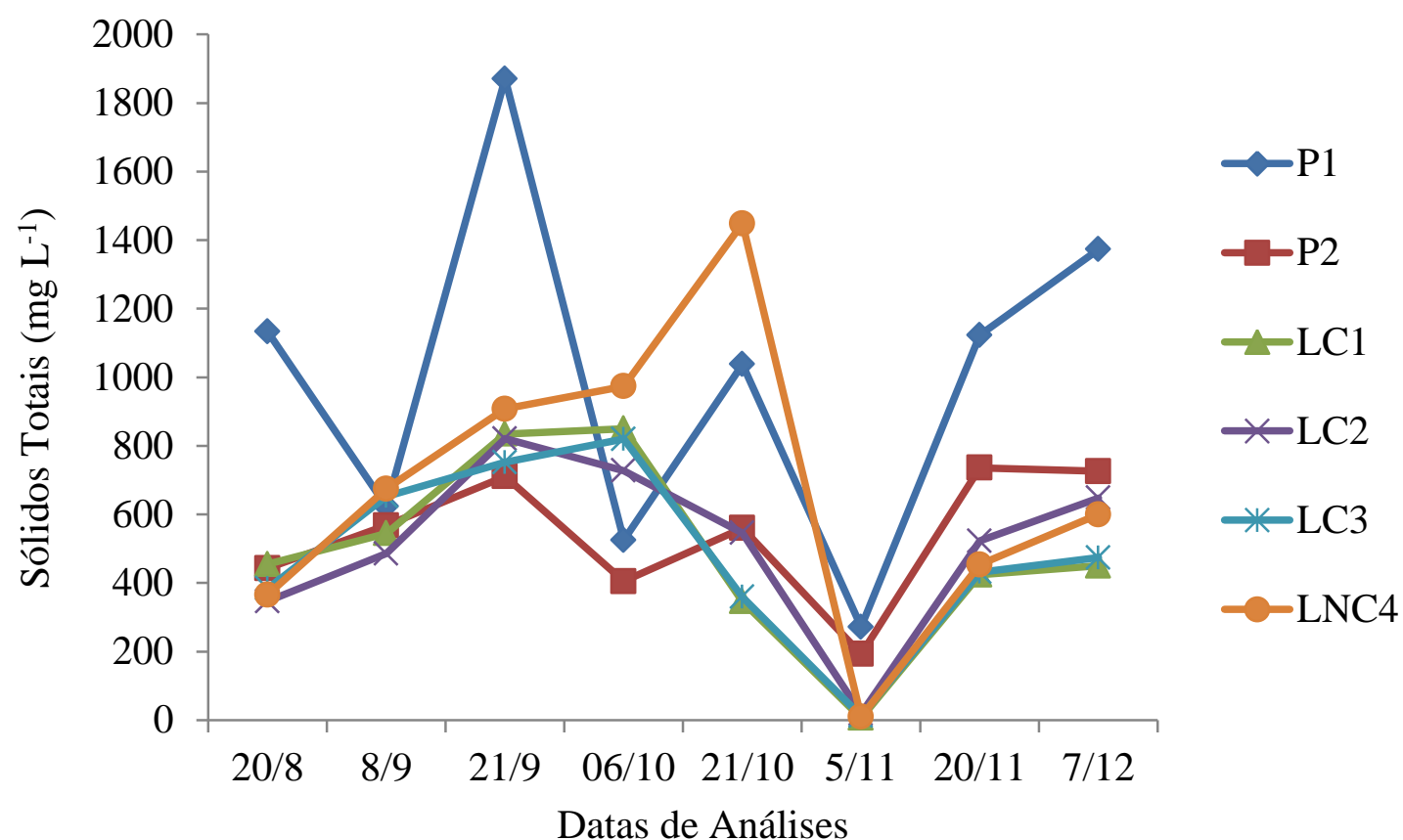

FIGURA 14. Valores médio de sólidos Totais, em $\mathrm{mg} \mathrm{L}^{-1}$, analisadas entre datas: 20 de agosto a 07 de dezembro de 2015.

Considerando que os tanques sépticos são unidades que desempenham a função de sedimentação e remoção de materiais flutuantes pela digestão anaeróbia da matéria orgânica e o adensamento do lodo, observa-se a significativa diminuição dos valores de 
ST no P2 (saída dos tanques sépticos), obtendo-se valores médios de $543 \mathrm{mg} \mathrm{L}^{-1}$, também mostrando resultados significativo de remoção de ST.

Quanto aos leitos cultivados, Chernicharo (2007) afirma que estes contribuem para a manutenção da qualidade da água, por meio da remoção e retenção de nutrientes, do processamento da matéria orgânica e resíduos químicos e da redução da carga de sedimentos descartada nos corpos receptores.

Os valores médio de ST foram $489 \mathrm{mg} \mathrm{L}^{-1}, 515 \mathrm{mg} \mathrm{L}^{-1}$ e $486 \mathrm{mg} \mathrm{L}^{-1}, 680 \mathrm{mg} \mathrm{L}^{-}$ 1 para LC1; LC2, LC3 e LNC4, respectivamente, valores bem menores que do efluente bruto, como esperado, porém, em alguns dias houve elevação de ST na saídas dos leitos, especialmente devido a variação de vazão da ETE ser muito elevada, o que movimenta a massa de fluido e transporte sólidos em suspensão.

No dia 5/11/2015, embora os SS aumentaram por apresentarem partículas sólidas em suspensão, os ST diminuíram, possivelmente pela redução do concentração de saídas e partículas coloidais (dimensões entre $1 \mathrm{~nm}$ e $1000 \mathrm{~nm}$ ), uniformemente dispersas num meio contínuo).

A Tabela 18 apresenta os valores de eficiência de remoção de sólido total entre a entrada (P1) e saída dos tanques sépticos (P2) e entre a entrada (P2) e saída dos leitos cultivados (LC1, LC2, LC3 e LNC4), para diferentes datas de coleta.

TABELA 18. Variação de sólidos totais na ETE (\%) entre a entrada (P1) e saída dos tanques sépticos (P2) e entre a entrada (P2) e saída dos leitos cultivados (LC1, LC2, LC3 e LNC4), para diferentes datas de coleta.

\begin{tabular}{cccccc}
\hline \multirow{2}{*}{$\begin{array}{c}\text { Datas de } \\
\text { coleta }\end{array}$} & \multicolumn{5}{c}{ Variação de sólidos totais na ETE (\%) } \\
\cline { 2 - 5 } $20 / 8$ & E.T.S. & LC1 & LC2 & LC3 & LNC4 \\
\cline { 2 - 6 } $4 / 9$ & 60,9 & $-2,7$ & 21,7 & 13,3 & 17,4 \\
$21 / 9$ & 8,8 & 4,0 & 14,4 & $-15,0$ & $-18,8$ \\
$6 / 10$ & 22,0 & $-17,4$ & $-15,5$ & $-5,8$ & $-27,7$ \\
$21 / 10$ & 46,1 & $-109,9$ & $-79,8$ & $-102,5$ & $-140,5$ \\
$5 / 11$ & 38,2 & 2,5 & 35,9 & $-158,7$ \\
$20 / 11$ & 34,5 & 46,9 & 90,2 & 93,8 & 94,8 \\
$7 / 12$ & 47,1 & 38,0 & 28,9 & 41,3 & 38,3 \\
\hline Média & 38,9 & 11,2 & 10,7 & 34,7 & 17,4 \\
DP & 18,6 & 60,3 & 47,2 & 12,0 & $-22,2$ \\
CV(\%) & 47,7 & 539,2 & 517,3 & 57,0 & 87,2 \\
p & - & \multicolumn{4}{c}{0,5616} \\
\hline
\end{tabular}

DP: Desvio Padrão (\%); CV: Coeficiente de variação (\%); P1: Esgoto bruto; P2: Saída do tanque séptico 3; LC1: Leito de cultivo 1 (Taboa); LC2: Leito de cultivo 2 (Papiro brasileiro); LC3: Leito de cultivo 3 (Lírio do brejo); LNC4: Leito de cultivo 4 (sem planta). E.T.S. Eficiência dos tanques sépticos (P1 a P2). Não houve diferença estatística entre os pontos de coleta pelo teste de Duncan a $5 \%$ de probabilidade; 
A porcentagem de remoção do E.T.S. foi 38,9\%, a outros autores que avaliaram a aplicação de tanques sépticos no tratamento de esgoto, como COLARES e SANDRI (2013), que obtiveram 28,7\% de remoção de ST e ALTVATER et al. (2009), que obtiveram 20,4 \% eficiência de remoção de ST, possivelmente devido ao elevado TDH, maior aos autores citados.

Os LC1, LC2 e LC3 apresentaram remoção de ST de 11,2\%, 9,2 \% e 12\%, respectivamente. O LNC4 não apresentou valor significativo na remoção de ST, o que pode se atribuir, em parte, ao fato de não ter macrófitas plantada nesse leito e a filtragem ser menor.

A Resolução Conama n. 430 não estabelece limites para o parâmetro de ST, apenas faz menção a materiais sedimentáveis que devem ser virtualmente ausente, ou seja, que não é perceptível pela visão, olfato ou paladar, para lançamento no corpo receptor.

\subsubsection{Sólidos Sedimentáveis (SS)}

O P1 apresentou valores de $0,58 \mathrm{~mL} \mathrm{~L}^{-1}$ a $10,63 \mathrm{~mL} \mathrm{~L}^{-1}$ de $\mathrm{SS}$, bastante variável entre as datas de coleta (DP de $124,29 \mathrm{~mL} \mathrm{~L}^{-1}$ no P2), devido ao fato do efluente bruto não apresentar um padrão de composição. A média de SS para P1 foi de $4,17 \mathrm{~mL} \mathrm{~L}^{-1} \mathrm{e}$ de $0,33 \mathrm{~mL} \mathrm{~L}^{-1}$ para P2, sem presença de SS na saída dos leitos de cultivos (Tabela 19).

TABELA 19. Valores de sólidos sedimentáveis, em $\mathrm{mL} \mathrm{L}^{-1}$, desvio padrão, coeficiente de variação, teste de comparação de médias e eficiência total entre a entrada (P1) e saída dos tanques sépticos (P2) e entre a entrada (P2) e saída dos leitos cultivados (LC1, LC2, LC3 e LNC4), para diferentes datas de coleta.

\begin{tabular}{ccccccc}
\hline \multirow{2}{*}{$\begin{array}{c}\text { Datas de } \\
\text { coleta }\end{array}$} & P1 & P2 & LC1 & LC2 & LC3 & LNC4 \\
\hline \cline { 2 - 7 } $20 / 8$ & 0,00 & 0,00 & 0,00 & 0,00 & 0,00 & 0,00 \\
$8 / 9$ & 3,30 & 0,00 & 0,00 & 0,00 & 0,00 & 0,00 \\
$21 / 9$ & 2,80 & 0,03 & 0,00 & 0,00 & 0,00 & 0,00 \\
$6 / 10$ & 0,58 & 0,01 & 0,00 & 0,00 & 0,00 & 0,00 \\
$21 / 10$ & 3,57 & 0,33 & 0,00 & 0,00 & 0,00 & 0,00 \\
$5 / 11$ & 10,63 & 0,10 & 0,00 & 0,00 & 0,00 & 0,00 \\
$20 / 11$ & 8,23 & 0,10 & 0,00 & 0,00 & 0,00 & 0,00 \\
$7 / 12$ & 4,23 & 0,33 & 0,00 & 0,00 & 0,00 & 0,00 \\
\hline Média & 4,17 & 0,11 & - & - & - & - \\
DP & 3,62 & 0,14 & - & - & - & - \\
CV $(\%)$ & 86,79 & 124,29 & - & - & - & - \\
p & 0,0068 & & & & & \\
\hline
\end{tabular}


DP: Desvio Padrão, em mL L ${ }^{-1}$; CV: Coeficiente de variação (\%); P1: Esgoto bruto; P2: Saída do tanque séptico 3; LC1: Leito de cultivo 1 (Taboa); LC2: Leito de cultivo 2 (Papiro brasileiro); LC3: Leito de cultivo 3 (Lírio do brejo); LNC4: Leito de cultivo 4 (sem planta).

Não houve diferença estatística entre os pontos de coleta pelo teste de Duncan a 5\% de probabilidade;

Os valores de SS entre os horários de coleta, mostra que o P1 apresenta valores muitos variáveis, já o P2 foi eficiente na remoção de SS, principalmente nos horários das 11:00 h e 13:00 h (Tabela 20).

TABELA 20. Valores de sólidos sedimentáveis, em $\mathrm{mL} \mathrm{L}^{-1}$, desvio padrão, coeficiente de variação, teste de comparação de médias e eficiência total entre a entrada (P1) e saída dos tanques sépticos (P2), para diferentes horários de coleta.

\begin{tabular}{ccccccc}
\hline \multirow{2}{*}{$\begin{array}{c}\text { Horário de } \\
\text { coleta }(\mathrm{h})\end{array}$} & $\mathrm{P} 1$ & $\mathrm{P} 2$ & LC1 & LC2 & LC3 & LNC4 \\
\hline 9:00 & $6,04 \mathrm{a}$ & $0,35 \mathrm{a}$ & - & - & - & - \\
$11: 00$ & $2,31 \mathrm{a}$ & $0,01 \mathrm{~b}$ & - & - & - & - \\
$13: 00$ & $4,66 \mathrm{a}$ & $0,01 \mathrm{~b}$ & - & - & - & - \\
\hline Média & 4,34 & 0,13 & - & - & - & - \\
DP & 1,89 & 0,20 & - & - & - & - \\
CV $(\%)$ & 43,45 & 156,06 & - & - & - & - \\
p & 0,629 & 0,01 & - & - & - & - \\
\hline
\end{tabular}

DP: Desvio Padrão, em mg L ${ }^{-1}$; CV: Coeficiente de variação (\%); P1: Esgoto bruto; P2: Saída do tanque séptico 3; LC1: Leito de cultivo 1 (Taboa); LC2: Leito de cultivo 2 (Papiro brasileiro); LC3: Leito de cultivo 3 (Lírio do brejo); LNC4: Leito de cultivo 4 (sem planta).

Não houve diferença estatística entre os pontos de coleta pelo teste de Duncan a 5\% de probabilidade;

Segundo a Resolução CONAMA, n ${ }^{\circ}$ 430/2011, o limite de materiais sedimentáveis presente em efluente para ser lançados em corpos receptores como lagos e lagoas é de até $1 \mathrm{~mL} \mathrm{~L}^{-1}$ em teste de 1 hora em cone Inmhoff. Considerando o esgoto tratado na ETE/FAL, só será descartado após passar pelos leitos de cultivos, em que o efluente não possui SS.

\subsubsection{Demanda Química de Oxigênio (DQO)}

As médias dos valores de DQO no P1 variaram entre 623,79 e 1863,00 $\mathrm{mg} \mathrm{L}^{-1}$ de $\mathrm{O}_{2}$, oscilando muito entre os dias de coleta, mas tendo uma média alta, ou seja, 1178,70 $\mathrm{mg} \mathrm{L}^{-1}$ de $\mathrm{O}_{2}$. No ponto $\mathrm{P} 2$ valores são considerados alto, variando entre 797,51 a $1720,00 \mathrm{mg} \mathrm{L}^{-1} \mathrm{O}_{2}$, média de $1287,19 \mathrm{mg} \mathrm{L}^{-1}$ de $\mathrm{O}_{2}$, acima das faixas especificadas para esgoto doméstico segundo Von SPERLING (2005), indicando que deve estar entre 450,0 mg L ${ }^{-1}$ a 800,0 $\mathrm{mg} \mathrm{L}^{-1}$; JORDÃO e PESSOA (2009), indicam entre 200,0 mg L $\mathrm{m}^{-1}$ 
800,0 mg L $\mathrm{m}^{-1}$, já METCALF e EDDY (2003) $250 \mathrm{mg} \mathrm{L}^{-1}$ a $1000 \mathrm{mg} \mathrm{L}^{-1}$ de $\mathrm{O}_{2}$, possivelmente devido a predominância de resíduos do refeitório (Tabela 21).

Os valores médios de DQO nos LC1, LC2, LC3 e LNC4 foram 457,25 mg L-1; $523,43 \mathrm{mg} \mathrm{L}^{-1}$ e $346,69 \mathrm{mg} \mathrm{L}^{-1}$ e 509,35 $\mathrm{mg} \mathrm{L}^{-1}$ de $\mathrm{O}_{2}$; respectivamente, próximos ao valores inferiores da faixa indicada por Von SPERLING (2005), mas dentro das faixas indicadas por METCALF e EDDY (2003) e JORDÃO e PESSOA (2009), ou seja, houve redução ao passar o efluente pelos leitos cultivados, enquanto que ao passar pelos tanques sépticos houve elevação, embora significativamente menores aos valores da saídas dos leitos, inclusive o sem plantas, mas maior aos que tem plantas, mostrando que estas auxiliaram na remoção de atributos biodegradáveis e não biodegradáveis.

Em tanques sépticos, de maneira geral, espera-se redução da carga orgânica entre a entrada e saída dos mesmos, e também de atributos como DQO, DBO, série de sólidos, dentre outros, no entanto, neste trabalho em particular, devido à carga de sólidos do chamado esgoto bruto, ser muito variável em função do tipo e frequência de uso do refeitório e dos sanitários, resulta que em determinados momentos, o descarte é basicamente água, com baixíssimos teores de sólidos. Caso a coleta de amostras na chegada do primeiro tanque séptico, coincidir com estes momentos de geração de esgoto, esta amostras terão carga de sólidos inferior a da saída dos mesmos, já que estes receberam material sólido em momentos anteriores e que ficou retido. Adicional a isso, pode ter havido turbulência devido a grande variação da vazão de esgoto produzido ou também criação de fluxo preferencial dentro dos tanques, favorecendo o carreamento de sólidos.

A DQO determina a quantidade de oxigênio necessária para oxidar a fração orgânica presente numa amostra que seja oxidável pelo permanganato ou dicromato de potássio em solução ácida e engloba todos os tipos de demandas de oxigênio, incluindo a DBO.

Analisando os valores médios de eficiência de remoção para E.T.S não foi eficiente, para LC1, LC2, LC3 e LNC4 (Tabela 21) com valores de 62 \%, 60,5\%, 71,6\% e 60,25\%, respectivamente, sendo que o LNC4( sem Planta) apresenta o menor valor de remoção de DQO. A médias de eficiência de remoção da DQO nos LC'S com macrofitas se deve ao fato da formação do biofilme no meio suporte e desenvolvimento das plantas, não obstante, a variabilidade e os altos valores de DQO no esgoto bruto (EB) pode ter afetado na remoção deste parâmetro. Nos LC com macrófitas o melhor 
resultado foi apresentado no LC2 cultivada com lírio do brejo, que obteve 71,6\% na remoção de DQO.

TABELA 21. Valores de DQO, em $\mathrm{mg} \mathrm{L}^{-1}$ de $\mathrm{O}_{2}$, desvio padrão, coeficiente de variação, teste de comparação de médias e eficiência total entre a entrada (P1) e saída dos tanques sépticos (P2) e entre a entrada (P2) e saída dos leitos cultivados (LC1, LC2, LC3 e LNC4), para diferentes datas de coleta.

\begin{tabular}{|c|c|c|c|c|c|c|c|c|c|c|c|}
\hline \multirow{2}{*}{$\begin{array}{c}\text { Datas de } \\
\text { coleta }\end{array}$} & \multicolumn{6}{|c|}{ Pontos de coleta } & \multicolumn{5}{|c|}{ Eficiências (\%) } \\
\hline & P1 & $\mathrm{P} 2$ & LC1 & $\mathrm{LC} 2$ & LC3 & LNC4 & T.S. & $\mathrm{LC} 1$ & $\mathrm{LC} 2$ & LC3 & LNC4 \\
\hline $20 / 8$ & - & - & - & - & - & - & - & - & - & - & - \\
\hline $8 / 9$ & 926,64 & 992,35 & 617,51 & 368,57 & 556,50 & 431,59 & $-7,1$ & 37,8 & 62,9 & 43,9 & 56,5 \\
\hline $21 / 9$ & 1415,88 & 1217,88 & 765,47 & 442,41 & 395,68 & 624 & 14,0 & 37,1 & 63,7 & 67,5 & 48,8 \\
\hline $6 / 10$ & 460,88 & 990,34 & 769,71 & 444,40 & 560,52 & 805,55 & $-114,9$ & 22,3 & 55,1 & 43,4 & 18,7 \\
\hline $21 / 10$ & 1863,78 & 1594,22 & 499,87 & 1850,73 & 44,75 & 635,91 & 14,5 & 68,6 & $-16,1$ & 97,2 & 60,1 \\
\hline $5 / 11$ & 1332,4 & 1697,64 & 0,00 & 0,00 & 254,26 & 508,00 & $-27,4$ & 100,0 & 100,0 & 85,0 & 70,1 \\
\hline $20 / 11$ & 623,79 & 797,51 & 0,00 & 145,89 & 0,00 & 0,00 & $-27,8$ & 100,0 & 81,7 & 100,0 & 100,0 \\
\hline $7 / 12$ & 1627,55 & 1720,38 & 548,21 & 412,02 & 615,13 & 560,25 & $-5,7$ & 68,1 & 76,1 & 64,2 & 67,4 \\
\hline & & & & & & & & & & & \\
\hline Média & $\mathrm{a}$ & $\mathrm{a}$ & $457,25 b$ & $523,43 b$ & $346,69 \mathrm{~b}$ & $509,35 \mathrm{~b}$ & $-22,1$ & 62,0 & 60,5 & 71,6 & 60,2 \\
\hline & & & 328,27 & & 253 & & 44,4 & 31,0 & 36,9 & 23,4 & 24,5 \\
\hline $\mathrm{CV}(\%)$ & 44,32 & 29,58 & 71,79 & 116,40 & 72,98 & 49,73 & $-201,0$ & 49,9 & 61,0 & 32,6 & 40,7 \\
\hline$P$ & & & & 001 & & & - & & 0,82 & & \\
\hline
\end{tabular}

DP: Desvio Padrão, em mg L ${ }^{-1}$ de $\mathrm{O}_{2}$; CV: Coeficiente de variação (\%); P1: Esgoto bruto; P2: Saída do tanque séptico 3; LC1: Leito de cultivo 1 (Taboa); LC2: Leito de cultivo 2 (Papiro brasileiro); LC3: Leito de cultivo 3 (Lírio do brejo); LNC4: Leito de cultivo 4 (sem planta); E.T.S. Eficiência dos tanques sépticos (P1 a P2).

Médias seguidas por letras iguais na linha não diferem entre si pelo teste de Duncan a $5 \%$ de probabilidade.

Para a DQO, o valor de eficiência de remoção para co conjunto de tanque séptico (E.T.S) não foi eficiente, diferente dos resultados avaliados por COLARES e SANDRI (2013), que estudaram a eficiência do tratamento de esgoto com tanques sépticos seguidos de leitos cultivados com diferentes meios de suporte, onde obtiveram valores médio na eficiência de remoção de DQO foi de 23,58\%.

Sendo a DQO uma medida indireta de matéria orgânica, COPPER et al. (1996) afirmaram que a remoção de material orgânico das águas residuárias em leitos cultivados de fluxo subsuperficial se processa basicamente através de mecanismos biológicos de decomposição aeróbia, com a utilização de oxigênio como aceptor final de elétrons (agente oxidante), e/ou por decomposição anaeróbia, em que os microrganismos utilizam outros aceptores de elétrons que não seja o oxigênio (sulfato, nitrato, gás carbônico). A comunidade microbiológica encontra-se disperso nos interstícios do meio filtrante ou aderido a ele, formando biofilme. 


\section{2. 11 Demanda Bioquímica de Oxigênio (DBO)}

Os valores de DBO no P1 variaram entre $140 \mathrm{mg} \mathrm{L}^{-1}$ a $762 \mathrm{mg} \mathrm{L}^{-1}$ de $\mathrm{O}_{2}$, oscilando muito entre os dias de coleta, mas tendo um valor médio de $518,13 \mathrm{mg} \mathrm{L}^{-1}$ de $\mathrm{O}_{2}$ (Tabela 22), sendo superiores as faixas apresentadas por SPERLING (2005), que 250,0 mg L $\mathrm{me} \mathrm{O}_{2}$ a 400,0 mg L $\mathrm{m}^{-1}$ de $\mathrm{O}_{2}$ e JORDÃO e PESSOA (2009) 100,0 mg L $\mathrm{me}^{-1} \mathrm{de}$ $\mathrm{O}_{2}$ a $400,0 \mathrm{mg} \mathrm{L}^{-1}$ de $\mathrm{O}_{2}$. No ponto $\mathrm{P} 2$ a foi em média de $629,25 \mathrm{mg} \mathrm{L}^{-1}$ de $\mathrm{O}_{2}$, superior ao $\mathrm{P} 1$, onde o conjunto de tanque séptico não implicou em remoção da DBO, sendo os fatores que podem ter influenciados na DBO no conjunto de TS pode ter sido devido aos picos de vazão e não estabilização completa do sistema. Ou seja, em função da vazão ser muito variável, os picos de vazão podem ter favorecido que sólidos se mantivessem em suspensão, sendo carreados para fora dos tanques.

Nos LC'S valor médio de DBO foram de $130,13 \mathrm{mg} \mathrm{L}^{-1} \mathrm{O}_{2}, 109,13 \mathrm{mg} \mathrm{L}^{-1} \mathrm{O}_{2}$ ' 94,75 mg L $\mathrm{m}^{-1} \mathrm{O}_{2}, 160,25 \mathrm{mg} \mathrm{L}^{-1} \mathrm{O}_{2}$, respectivamente, para LC1, LC2, LC3 e LNC4 (Tabela 27), diferindo dos valores nos P1e P2. Ainda para os LC'S, as eficiências de remoção de DBO para LC1, LC2, LC3 e LNC4, foram 76,2\%, 81,7, 82,9 e 71,5\%, respectivamente, com valores de remoção de DQO muito próximos.

TABELA 22. Valores de DBO, em $\mathrm{mg} \mathrm{L}^{-1}$ de $\mathrm{O}_{2}$, desvio padrão, coeficiente de variação, teste de comparação de médias e eficiência total entre a entrada (P1) e saída dos tanques sépticos (P2) e entre a entrada (P2) e saída dos leitos cultivados (LC1, LC2, LC3 e LNC4), para diferentes datas de coleta.

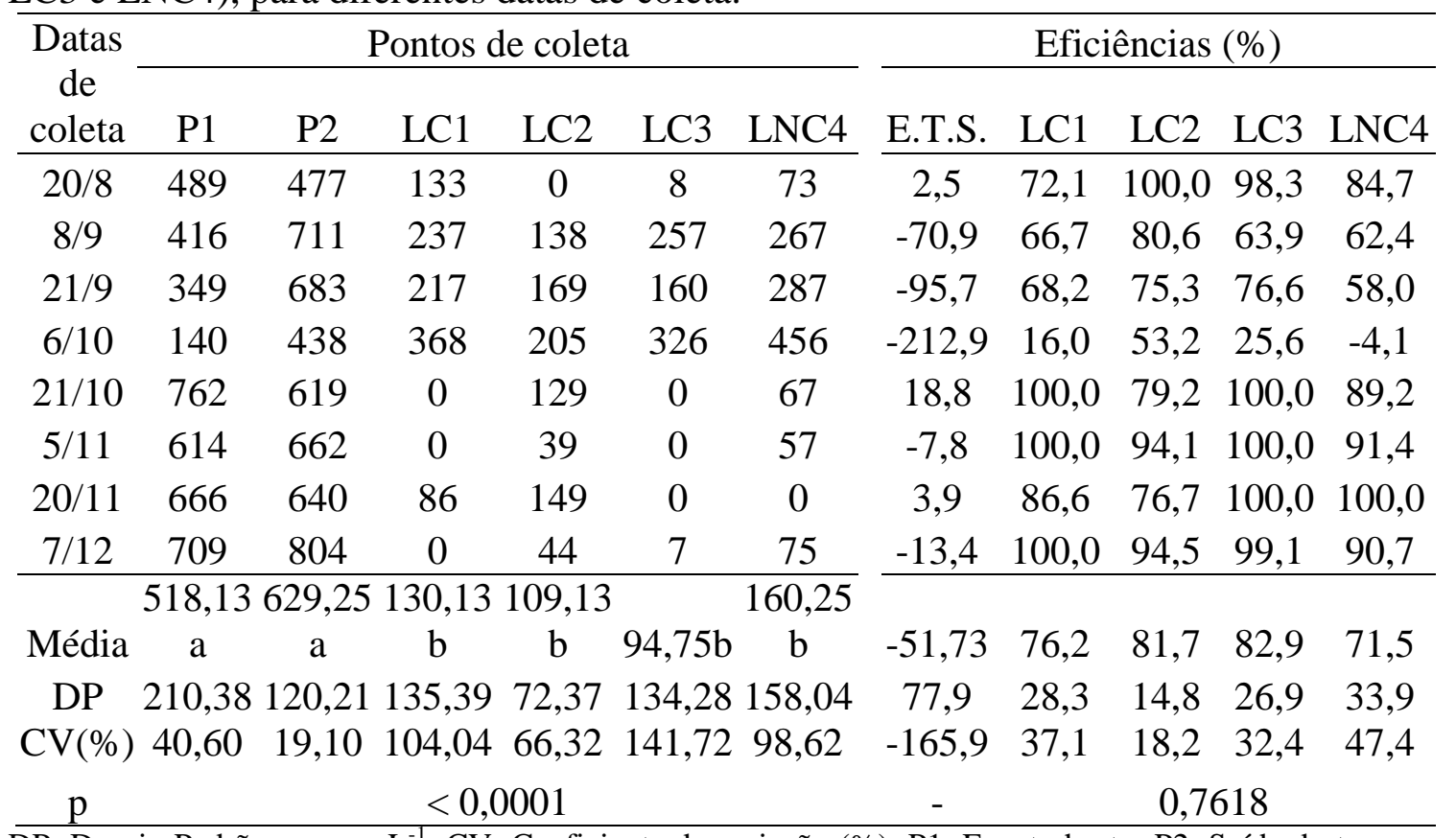

DP: Desvio Padrão, em mg L ${ }^{-1}$; CV: Coeficiente de variação (\%); P1: Esgoto bruto; P2: Saída do tanque séptico 3; LC1: Leito de cultivo 1 (Taboa); LC2: Leito de cultivo 2 (Papiro brasileiro); LC3: Leito de 
cultivo 3 (Lírio do brejo); LNC4: Leito de cultivo 4 (sem planta); E.T.S. Eficiência dos tanques sépticos (P1 a P2).

Médias seguidas por letras iguais na linha não diferem entre si pelo teste de Duncan a $5 \%$ de probabilidade.

A resolução CONAMA n.430 (BRASIL, 2011) preconiza o limite de 120 mg L-1 para o lançamento de efluentes oriundos de sistemas de tratamento de esgotos sanitários, ou, eficiência de remoção mínima de $60 \%$ para DBO. Conforme valores apresentados neste estudo, os resultados obtidos nos LC1, LC2, LC3 e LNC4 atendem a esta resolução.

A DBO consiste num teste empírico que corresponde à diferença entre as concentrações de oxigênio no início e no fim de um período de incubação, em condições específicas do ensaio. A temperatura de incubação é padronizada em $20{ }^{\circ} \mathrm{C}$ e o tempo em 5 dias. Admite-se que neste as condições $80 \%$ da matéria orgânica carbonatada já estejam mineralizadas e começando a nitrificação.

\section{2. 12 Nitrito $\left(\mathrm{NO}_{2}\right)$ e Nitrato $\left(\mathrm{NO}_{3}{ }^{-}\right)$e Amônia $\left(\mathrm{NH}^{4+}\right)$}

Segundo Sperling (2005) no meio aquático, o nitrogênio pode ser encontrado de diversas formas, entre elas, na forma de $\mathrm{NO}_{2}{ }^{-}$e $\mathrm{NO}_{3}{ }^{-}$. As Tabelas 23 e 24 apresentam os valores de $\mathrm{NO}_{2}{ }^{-}$e $\mathrm{NO}_{3}{ }^{-}$nos pontos analisados e datas de coleta. $\mathrm{O}$ valor médio de nitrato no P1 foi de $1,100 \mathrm{mg} \mathrm{L}^{-1}$, no P2 $0,660 \mathrm{mg} \mathrm{L}^{-1}$, e na saída dos leitos de cultivos foram de $0,100 \mathrm{mg} \mathrm{L}^{-1}, 0,100 \mathrm{mg} \mathrm{L}^{-1}, 0,070 \mathrm{mg} \mathrm{L}^{-1}$, e $0,100 \mathrm{mg} \mathrm{L}^{-1}$, respectivamente, para LC1, LC2, LC3 e LNC4 (Tabela 23), ou seja, significativamente menores aos P1 e $\mathrm{P} 2$.

$\mathrm{O}$ valor médio de nitrito no P1 foi de $0,09 \mathrm{mg} \mathrm{L}^{-1}$, no P2 $0,05 \mathrm{mg} \mathrm{L}^{-1}$, para os leitos de cultivos foram de $0,01 \mathrm{mg} \mathrm{L}^{-1}, 0,01 \mathrm{mg} \mathrm{L}^{-1}, 0,01 \mathrm{mg} \mathrm{L}^{-1}$, e $0,01 \mathrm{mg} \mathrm{L}^{-1}$, respectivamente, para LC1, LC2, LC3 e LNC4 (Tabela 24). Os resultados médios obtidos para $\mathrm{NO}_{3}{ }^{-}$para $\mathrm{P} 1$ e P2 foram superiores aos LC'S, não havendo diferença significativa para P1, apresentando diferença significativa para os demais pontos, principalmente nos LC'S, com baixo desvio padrão. 
TABELA 23. Valores de Nitrato, em $\mathrm{mg} \mathrm{L}^{-1}$, desvio padrão, coeficiente de variação, teste de comparação de médias e eficiência total entre a entrada (P1) e saída dos tanques sépticos (P2) e entre a entrada (P2) e saída dos leitos cultivados (LC1, LC2, LC3 e LNC4), para diferentes datas de coleta.

\begin{tabular}{|c|c|c|c|c|c|c|c|c|c|c|c|}
\hline \multirow{2}{*}{$\begin{array}{c}\text { Datas } \\
\text { de } \\
\text { coleta }\end{array}$} & \multicolumn{6}{|c|}{ Pontos de coleta } & \multicolumn{5}{|c|}{ Eficiências (\%) } \\
\hline & $\mathrm{P} 1$ & $\mathrm{P} 2$ & $\mathrm{LC} 1$ & $\mathrm{LC} 2$ & LC3 & LNC4 & E.T.S. & $\mathrm{LC} 1$ & $\mathrm{LC} 2$ & LC3 & LNC4 \\
\hline $20 / 8$ & - & - & - & & - & - & - & - & - & - & - \\
\hline $8 / 9$ & 0,583 & 0,554 & 0,128 & 0,087 & 0,072 & 0,080 & 5,0 & 76,9 & 84,3 & 87,0 & 85,6 \\
\hline $21 / 9$ & 1,460 & 0,562 & 0,000 & 0,000 & 0,000 & 0,000 & 61,5 & 100,0 & 100,0 & 100,0 & 100,0 \\
\hline $6 / 10$ & 0,228 & 0,486 & 0,145 & 0,162 & 0,150 & 0,188 & $-113,2$ & 70,2 & 66,7 & 69,1 & 61,3 \\
\hline $21 / 10$ & 1,232 & 0,637 & 0,056 & 0,098 & 0,062 & 0,073 & 48,3 & 91,2 & 84,6 & 90,3 & 88,5 \\
\hline $5 / 11$ & 1,774 & 0,874 & 0,049 & 0,095 & 0,066 & 0,105 & 50,7 & 94,4 & 89,1 & 92,4 & 88,0 \\
\hline $20 / 11$ & 0,750 & 0,732 & 0,230 & 0,186 & 0,160 & 0,191 & 2,4 & 68,6 & 74,6 & 78,1 & 73,9 \\
\hline $7 / 12$ & 1,665 & 0,749 & 0,110 & 0,114 & 0,001 & 0,055 & 55,0 & 85,3 & 84,8 & 99,9 & 92,7 \\
\hline Média & $1,100 \mathrm{a}$ & $0,660 \mathrm{~b}$ & $0,100 \mathrm{c}$ & $0,110 \mathrm{c}$ & $0,070 \mathrm{c}$ & $0,100 \mathrm{c}$ & 15,7 & 83,8 & 83,4 & 88,1 & 84,3 \\
\hline DP & 0,59 & 0,14 & 0,08 & 0,06 & 0,06 & 0,07 & 61,7 & 12,2 & 10,6 & 11,3 & 12,8 \\
\hline $\mathrm{CV}(\%)$ & 53,46 & 20,67 & 73,71 & 56,32 & 86,97 & 70,56 & 393,4 & 14,6 & 12,7 & 12,8 & 15,2 \\
\hline $\mathrm{p}$ & & & $<0$, & & & & - & & & & \\
\hline
\end{tabular}

DP: Desvio Padrão, em $\mathrm{mg} \mathrm{L}^{-1}$; CV: Coeficiente de variação (\%); P1: Esgoto bruto; P2: Saída do tanque séptico 3; LC1: Leito de cultivo 1 (Taboa); LC2: Leito de cultivo 2 (Papiro brasileiro); LC3: Leito de cultivo 3 (Lírio do brejo); LNC4: Leito de cultivo 4 (sem planta); E.T.S. Eficiência dos tanques sépticos (P1 a P2).

Médias seguidas por letras iguais na linha não diferem entre si pelo teste de Duncan a $5 \%$ de probabilidade.

A eficiência de remoção de nitrito no E.T.S foi de $20 \%$, sendo baixo, comparado com dos LC'S. O baixo valor de eficiência nos TS (E.T.S) são reforçados por ALTVATER (2008), que afirma que os tanques sépticos quanto à remoção de matéria orgânica, é moderada, devido a isso, sendo necessário um pós-tratamento.

A eficiência de remoção de nitrito para os LC'S foram de 83,2\%, 81,6\%, 83,6\% e 80,4\% para LC1, LC2, LC3 e LNC4, respectivamente, considerados elevados. A Resolução Conama n.357 (BRASIL, 2005) não cita limites de remoção de $\mathrm{NO}_{2}{ }^{-}$e $\mathrm{NO}_{3^{-}}$ para lançamento de efluentes, porém, a Resolução Conama n.20, define o limite de concentração máxima de $\mathrm{NO}_{2^{-}}$com $1,0 \mathrm{mg} \mathrm{L}{ }^{-1}$. $\mathrm{O} \mathrm{NO}_{3^{-}}$que são tóxicos, podendo causar a doença chamada metahemoglobinemia infantil, que é letal para crianças, com concentração máxima de $10,0 \mathrm{mg} \mathrm{L}^{-1}$ em corpos hídricos de Classe 2. Ressalta-se que todos os valores avaliados na pesquisa estão abaixo dos limites especificados. 
TABELA 24. Valores de Nitrito, em $\mathrm{mg} \mathrm{L}^{-1}$, desvio padrão, coeficiente de variação, teste de comparação de médias e eficiência total entre a entrada (P1) e saída dos tanques sépticos (P2) e entre a entrada (P2) e saída dos leitos cultivados (LC1, LC2, LC3 e LNC4), para diferentes datas de coleta.

\begin{tabular}{|c|c|c|c|c|c|c|c|c|c|c|c|}
\hline \multirow{2}{*}{$\begin{array}{c}\text { Datas } \\
\text { de } \\
\text { coleta }\end{array}$} & \multicolumn{6}{|c|}{ Pontos de coleta } & \multicolumn{5}{|c|}{ Eficiências (\%) } \\
\hline & $\mathrm{P} 1$ & $\mathrm{P} 2$ & $\mathrm{LC} 1$ & LC2 & LC3 & LNC4 & E.T.S. & $\mathrm{LC} 1$ & LC2 & LC3 & LNC4 \\
\hline $20 / 8$ & & 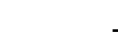 & & 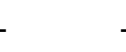 & - & & - & - & - & - & - \\
\hline $8 / 9$ & 0,049 & 0,042 & 0,007 & 0,007 & 0,007 & 0,011 & 14,3 & 83,3 & 83,3 & 83,3 & 73,8 \\
\hline $21 / 9$ & 0,124 & 0,051 & 0,008 & 0,007 & 0,006 & 0,009 & 58,9 & 84,3 & 86,3 & 88,2 & 82,4 \\
\hline $6 / 10$ & 0,017 & 0,036 & 0,012 & 0,009 & 0,011 & 0,013 & $-111,8$ & 66,7 & 75,0 & 69,4 & 63,9 \\
\hline $21 / 10$ & 0,106 & 0,047 & 0,007 & 0,009 & 0,008 & 0,01 & 55,7 & 85,1 & 80,9 & 83,0 & 78,7 \\
\hline $5 / 11$ & 0,142 & 0,067 & 0,004 & 0,007 & 0,004 & 0,007 & 52,8 & 94,0 & 89,6 & 94,0 & 89,6 \\
\hline 20/11 & 0,061 & 0,054 & 0,008 & 0,014 & 0,007 & 0,008 & 11,5 & 85,2 & 74,1 & 87,0 & 85,2 \\
\hline $7 / 12$ & 0,132 & 0,055 & 0,009 & 0,01 & 0,011 & 0,006 & 58,3 & 83,6 & 81,8 & 80,0 & 89,1 \\
\hline Média & $0,09 a$ & $0,05 b$ & $0,01 \mathrm{c}$ & $0,01 \mathrm{c}$ & $0,01 \mathrm{c}$ & $0,01 \mathrm{c}$ & 20,0 & 83,2 & 81,6 & 83,6 & 80,4 \\
\hline $\mathrm{DP}$ & 0,05 & 0,01 & 0,00 & 0,00 & 0,00 & 0,00 & 61,6 & 8,2 & 5,6 & 7,7 & 9,2 \\
\hline $\mathrm{CV}(\%)$ & 53,07 & 19,88 & 30,68 & 27,96 & 33,23 & 26,36 & 308,9 & 9,8 & 6,9 & 9,2 & 11,4 \\
\hline $\mathrm{p}$ & & & $<0$, & 0001 & & & - & & & & \\
\hline
\end{tabular}

DP: Desvio Padrão, em mg L ${ }^{-1}$; CV: Coeficiente de variação (\%); P1: Esgoto bruto; P2: Saída do tanque séptico 3; LC1: Leito de cultivo 1 (Taboa); LC2: Leito de cultivo 2 (Papiro brasileiro); LC3: Leito de cultivo 3 (Lírio do brejo); LNC4: Leito de cultivo 4 (sem planta); E.T.S. Eficiência dos tanques sépticos (P1 a P2).

Médias seguidas por letras iguais na linha não diferem entre si pelo teste de Duncan a $5 \%$ de probabilidade.

O valor médio de Amônia no P1 foi de $1,83 \mathrm{mg} \mathrm{L}^{-1}$, no P2 0,63 $\mathrm{mg} \mathrm{L}^{-1}$, já para os leitos de cultivos foram de $1,83 \mathrm{mg} \mathrm{L}^{-1}, 1,50 \mathrm{mg} \mathrm{L}^{-1}, 2,01 \mathrm{mg} \mathrm{L}^{-1}$, e $1,97 \mathrm{mg} \mathrm{L}^{-1}$, respectivamente, para LC1, LC2, LC3 e LNC4 (Tabela 25). O P2 apresentou média significativamente menor aos LC3 e LNC4, porém, em valor absoluto, P2 foi menor que todos os pontos, ou seja, redução ao passar pelos tanques sépticos e voltando a aumentar ao passar pelos leitos cultivados.

O E.T.S. apresentou eficiência de 28,5 \% na remoção de amônia, o mesmo não ocorreu nos leitos cultivados. A taboa (LC1) não foi eficiente na remoção de amônia, como observado em outros trabalhos, como SANTOS (2009) que avaliou um sistema sequencial de pós-tratamento por leitos cultivados compreendido por três unidades, duas de fluxo vertical (LCFV) em paralelo seguidos de um de fluxo horizontal (LCFH), ambos cultivados com Typha sp.( taboa), obtendo remoção de nitrogênio amoniacal de $57,8 \%$ e acréscimo de nitrato de $40 \%$ nos LCFV e indicação da ocorrência da nitrificação no LCFH com o crescimento $13 \%$ de nitrato. 
TABELA 25. Valores de Amônia, em mg L ${ }^{-1}$, desvio padrão, coeficiente de variação, teste de comparação de médias e eficiência total entre a entrada (P1) e saída dos tanques sépticos (P2) e entre a entrada (P2) e saída dos leitos cultivados (LC1, LC2, LC3 e LNC4), para diferentes datas de coleta.

\begin{tabular}{|c|c|c|c|c|c|c|c|c|c|c|c|}
\hline \multirow{2}{*}{$\begin{array}{c}\text { Datas } \\
\text { de } \\
\text { coleta }\end{array}$} & \multicolumn{6}{|c|}{ Pontos de coleta } & \multicolumn{5}{|c|}{ Eficiências (\%) } \\
\hline & $\mathrm{P} 1$ & $\mathrm{P} 2$ & $\mathrm{LC} 1$ & $\mathrm{LC} 2$ & LC3 & LNC4 & E.T.S. & LC1 & LC2 & LC3 & LNC4 \\
\hline $20 / 8$ & - & & - & . & & & - & - & - & - & - \\
\hline $8 / 9$ & 2,445 & 0,993 & 2,341 & 0,337 & 2,496 & 2,4 & 59,4 & $-135,8$ & 66,1 & $-151,4$ & $-141,7$ \\
\hline $21 / 9$ & 2,966 & 0,959 & 1,837 & 2,225 & 2,875 & 2,149 & 67,7 & $-91,6$ & $-132,0$ & $-199,8$ & $-124,1$ \\
\hline $6 / 10$ & 0,054 & 0,131 & 0,000 & 0,223 & 0,000 & 0,032 & $-142,6$ & 100,0 & $-70,2$ & 100,0 & 75,6 \\
\hline $21 / 10$ & 2,692 & 0,259 & 1,797 & 1,448 & 0,225 & 0,812 & 90,4 & $-593,8$ & $-459,1$ & 13,1 & $-213,5$ \\
\hline $5 / 11$ & & & 3,58 & & & & 42,3 & $-278,2$ & $-262,2$ & 5,4 & $-233,2$ \\
\hline $20 / 11$ & 0,750 & 0,752 & 1,459 & 1,275 & 2,452 & 1,826 & & $-94,0$ & $-69,5$ & & $-142,8$ \\
\hline $7 / 12$ & 2,252 & 0,387 & 1,753 & 1,572 & 2,152 & 3,408 & 82,8 & $-353,0$ & -306 & & $-780,6$ \\
\hline Média & $1,83 \mathrm{ab}$ & $0,63 b$ & $1,83 \mathrm{ab}$ & $1,50 a b$ & $2,01 \mathrm{a}$ & $1,97 \mathrm{a}$ & 28,5 & $-206,6$ & $-176,2$ & $-175,1$ & $-222,9$ \\
\hline DP & & & & & & & & 224,1 & & 187,4 & 265,6 \\
\hline $\mathrm{CV}(\%)$ & 58,82 & 57,78 & 58,54 & 73,51 & 69,89 & 61,56 & 284,6 & $-108,5$ & $-100,4$ & $-107,1$ & $-119,1$ \\
\hline $\mathrm{p}$ & & & 0,1 & 866 & & & - & & 0,8 & 574 & \\
\hline
\end{tabular}

DP: Desvio Padrão, em mg L ${ }^{-1}$; CV: Coeficiente de variação (\%); P1: Esgoto bruto; P2: Saída do tanque séptico 3; LC1: Leito de cultivo 1 (Taboa); LC2: Leito de cultivo 2 (Papiro brasileiro); LC3: Leito de cultivo 3 (Lírio do brejo); LNC4: Leito de cultivo 4 (sem planta); E.T.S. Eficiência dos tanques sépticos (P1 a P2).

Médias seguidas por letras iguais na linha não diferem entre si pelo teste de Duncan a $5 \%$ de probabilidade.

\section{2. 13 Fosfato total $\left(\mathrm{PO}_{4}{ }^{3-}\right)$}

No P1 (esgoto bruto), os valores de $\mathrm{PO}_{4}{ }^{3-}$ variam entre $0,054 \mathrm{mg} \mathrm{L}^{-1}$ a 2,692 $\mathrm{mg} \mathrm{L}^{-1}$ (Tabela 26), com média de $1,76 \mathrm{mg} \mathrm{L}^{-1}$, com elevada variação entre as datas de coleta, podendo ser atribuído a variável composição do esgotos gerado na FAL, contendo resíduos dos sanitários e do refeitório, onde são utilizados detergentes sintéticos e sanitizantes para higienização das instalações. Já no P2 foi inferior $(0,67$ $\mathrm{mg} \mathrm{L}^{-1}$ ), embora não significativo, onde o $\mathrm{CV}$ foi de $66 \%$.

Nos leitos de cultivos o $\mathrm{PO}_{4}{ }^{3-}$ foi de $1,84 \mathrm{mg} \mathrm{L}^{-1}, 1,49 \mathrm{mg} \mathrm{L}^{-1}, 1,98 \mathrm{mg} \mathrm{L}^{-1}$, e $1,73 \mathrm{mg} \mathrm{L} \mathrm{L}^{-1}$, respectivamente, para LC1, LC2, LC3 e LNC4 (Tabela 26), próximos a média observada no efluente bruto (P1), porém, mais elevado, em valor absoluto, ao P2. Segundo Valentim (2003), as formas potenciais de remoção de fósforo em sistemas naturais incluem o consumo pelas plantas, outros processos biológicos, adsorção e precipitação. Estudos envolvendo sistemas de leitos cultivados têm apresentado valores 
elevados na remoção de $\mathrm{PO}_{4}{ }^{3-}$, entretanto não foi essa a tendência demonstrada no estudo em questão.

TABELA 26. Valores de Fosfato, em $\mathrm{mg} \mathrm{L}^{-1} \mathrm{PO}_{4}{ }^{3-}$, desvio padrão, coeficiente de variação, teste de comparação de médias e eficiência total entre a entrada (P1) e saída dos tanques sépticos (P2) e entre a entrada (P2) e saída dos leitos cultivados (LC1, LC2, LC3 e LNC4), para diferentes datas de coleta.

\begin{tabular}{ccccccc}
\hline Datas de & \multicolumn{7}{c}{ Pontos de coleta } \\
\cline { 2 - 7 } coleta & P1 & P2 & LC1 & LC2 & LC3 & LNC4 \\
\hline $20 / 8$ & - & - & - & - & - & - \\
$8 / 9$ & 2,445 & 0,993 & 2,341 & 0,337 & 2,496 & 2,400 \\
$21 / 9$ & 2,966 & 0,959 & 1,837 & 2,225 & 2,875 & 2,149 \\
$6 / 10$ & 0,054 & 0,131 & 0,000 & 0,223 & 0,000 & 0,032 \\
$21 / 10$ & 2,692 & 0,259 & 1,797 & 1,448 & 0,225 & 0,812 \\
$5 / 11$ & 1,645 & 0,949 & 3,589 & 3,437 & 3,847 & 3,162 \\
$20 / 11$ & 0,750 & 0,752 & 1,459 & 1,275 & 2,452 & 1,826 \\
$7 / 12$ & - & - & - & - & - & - \\
\hline Média & 1,76 & 0,67 & 1,84 & 1,49 & 1,98 & 1,73 \\
DP & 1,16 & 0,38 & 1,17 & 1,21 & 1,53 & 1,13 \\
CV $(\%)$ & 66,00 & 56,77 & 63,68 & 81,13 & 77,41 & 65,44 \\
p & \multicolumn{7}{c}{0,4317} & & \\
\hline
\end{tabular}

DP: Desvio Padrão, em mg L ${ }^{-1}$; CV: Coeficiente de variação (\%); P1: Esgoto bruto; P2: Saída do tanque séptico 3; LC1: Leito de cultivo 1 (Taboa); LC2: Leito de cultivo 2 (Papiro brasileiro); LC3: Leito de cultivo 3 (Lírio do brejo); LNC4: Leito de cultivo 4 (sem planta); E.T.S. Eficiência dos tanques sépticos (P1 a P2).

Não houve diferença estatística entre os pontos de coleta pelo teste de Duncan a 5\% de probabilidade; - análises não realizadas

O fósforo está presente nos efluentes nas formas orgânica, inorgânica complexa (polifosfatos), como aquelas utilizadas em detergentes, e ortofosfato inorgânico solúvel, este como produto final no ciclo do fósforo e a forma mais prontamente disponível para uso biológico.

Uma consideração que pode ser feita é que o fósforo solúvel é facilmente absorvido pelos sistemas radiculares das plantas aquáticas e a fração pouco solúvel associa-se ao ferro, ao alumínio e ao cálcio, tornando-se pouco assimilável, bem como pelos microrganismos (METCALF e EDDY, 1991).

Durante a realização da pesquisa, não foi realizada a poda da vegetação presente nos leitos. Segundo Reed et al. (1995), a retirada de fósforo pelas plantas pode ser significante em sistemas de baixa taxa e fluxo superficial quando a colheita da vegetação é praticada rotineiramente. Nestes casos a colheita pode representar de $20 \%$ a $30 \%$ da remoção de fósforo, porém a vegetação usada nos leitos cultivados não é considerada um fator significante na remoção de fósforo, pois, se não for realizada a 
colheita, o fósforo retorna para o sistema aquático devido ao decaimento natural da vegetação. Tal fato foi confirmado por Sousa et al. (2004), monitorando um mesmo sistema por três anos, mostraram que a partir do segundo ano houve significativo decaimento da remoção de fósforo, fenômeno que, provavelmente, resulta da saturação do meio por este elemento.

\section{2. 14 Potássio $\left(\mathrm{K}^{+}\right)$}

Os valores médios de $\mathrm{K}^{+}$no $\mathrm{P} 1$ foi $43,67 \mathrm{mg} \mathrm{L}^{-1}$ e no P2 $60,55 \mathrm{mg} \mathrm{L}^{-1}$, já nos leitos foram de $47,77 \mathrm{mg} \mathrm{L}^{-1}, 46,31 \mathrm{mg} \mathrm{L}^{-1}, 50,96 \mathrm{mg} \mathrm{L}^{-1}$, e $53,68 \mathrm{mg} \mathrm{L}^{-1}$, respectivamente, para LC1, LC2, LC3 e LNC4 (Tabela 32), não havendo diferença significativa entre os pontos analisados, com elevados valores de DP e CV, tanto nos valores de $\mathrm{K}^{+}$medidos como nas eficiências calculados, que foram 18,0\%, 17,3\% , 9,7\% e 7,0\% para os LC1, LC2, LC3 e LNC4, respectivamente. Então, houve elevação de $\mathrm{K}^{+}$nos tanques sépticos e redução nos leitos, embora nos dias 21/9 e 06/10/15 houve elevação também todos os leitos (Tabela 27).

TABELA 27. Valores de potássio, em $\mathrm{mg} \mathrm{L}^{-1}$, desvio padrão, coeficiente de variação, teste de comparação das médias na entrada (P1) e saída dos tanques sépticos (P2) e entre a entrada (P2) e saída dos leitos cultivados (LC1, LC2, LC3 e LNC4), para diferentes datas de coleta.

\begin{tabular}{|c|c|c|c|c|c|c|}
\hline \multirow{2}{*}{$\begin{array}{c}\text { Datas de } \\
\text { coleta }\end{array}$} & \multicolumn{6}{|c|}{ Pontos de coleta } \\
\hline & $\mathrm{P} 1$ & $\mathrm{P} 2$ & LC1 & $\mathrm{LC} 2$ & LC3 & LNC4 \\
\hline $20 / 8$ & 32,97 & 31,73 & 20,18 & 24,72 & 24,31 & 21,83 \\
\hline $8 / 9$ & 16,47 & 56,08 & 35,45 & 33,38 & 39,57 & 42,05 \\
\hline $21 / 9$ & 74,4 & 79,7 & 96,9 & 70,7 & 99,8 & 111,8 \\
\hline $6 / 10$ & 34,0 & 57,2 & 108,8 & 83,4 & 98,4 & 111,8 \\
\hline $21 / 10$ & 38,2 & 47,4 & 38,9 & 35,3 & 41,0 & 34,6 \\
\hline $5 / 11$ & 35,3 & 121,8 & 33,9 & 41,0 & 29,0 & 36,0 \\
\hline $20 / 11$ & 70,6 & 43,12 & 30,38 & 40,3 & 37,46 & 31,08 \\
\hline $7 / 12$ & 47,38 & 47,38 & 17,62 & 41,71 & 38,16 & 40,3 \\
\hline Média & 43,67 & 60,55 & 47,77 & 46,31 & 50,96 & 53,68 \\
\hline $\mathrm{DP}$ & 19,75 & 28,36 & 34,92 & 20,04 & 30,25 & 36,39 \\
\hline $\mathrm{CV}(\%)$ & 45,24 & 46,84 & 73,10 & 43,26 & 59,35 & 67,80 \\
\hline $\mathrm{p}$ & \multicolumn{6}{|c|}{0,8808} \\
\hline
\end{tabular}

DP: Desvio Padrão, em mg L ${ }^{-1}$; CV: Coeficiente de variação (\%); P1: Esgoto bruto; P2: Saída do tanque séptico 3; LC1: Leito de cultivo 1 (Taboa); LC2: Leito de cultivo 2 (Papiro brasileiro); LC3: Leito de cultivo 3 (Lírio do brejo); LNC4: Leito de cultivo 4 (sem planta); E.T.S. Eficiência dos tanques sépticos (P1 a P2).

Não houve diferença estatística entre os pontos de coleta pelo teste de Duncan a 5\% de probabilidade; 
O LC1 (taboa) e o LC2 (papiro-brasileiro) tiveram maior redução de $\mathrm{K}^{+}$, podendo estar relacionado ao maior desenvolvimento dessas plantas.

\subsubsection{Sódio $\left(\mathrm{Na}^{+}\right)$}

Os valores de sódio $\left(\mathrm{Na}^{+}\right)$no P1 (Efluente bruto) variam entre 20,36 $\mathrm{mg} \mathrm{L}^{-1}$ a $214,82 \mathrm{mg} \mathrm{L}^{-1}$ (Tabela 28), ou seja, houve grande variabilidade das concentrações de $\mathrm{Na}+$, o que pode ser explicado pela própria composição do esgoto, podendo ter contribuições de produtos utilizados na higienização e limpeza do refeitório.

Matos (2008) afirma que as águas residuárias são ricas em macro e micronutrientes e grande parte desses nutrientes é disponibilizada apenas com a mineralização do material orgânico, exceção feita ao potássio e sódio, pois se considera que não estejam associados ao material orgânico e, portanto, não dependem da mineralização para serem disponibilizados no meio.

Os valores médios de $\mathrm{Na}^{+}$são de $119,30 \mathrm{mg} \mathrm{L}^{-1}$ no P1 e de $130,13 \mathrm{mg} \mathrm{L}^{-1}$ em P2 (saída dos tanques sépticos), já nos LC1, LC2, LC3 e LNC4 foram 114,92 mg L ${ }^{-1}$, $133,49 \mathrm{mg} \mathrm{L}^{-1}, 121,65 \mathrm{mg} \mathrm{L}^{-1}, 116,61 \mathrm{mg} \mathrm{L}^{-1}$, respectivamente.

TABELA 28. Valores de sódio, em $\mathrm{mg} \mathrm{L}^{-1}$, desvio padrão, coeficiente de variação, teste de comparação de médias para os diferentes pontos e datas de coleta.

\begin{tabular}{ccccccc}
\hline Datas de & \multicolumn{6}{c}{ Pontos de coleta } \\
\cline { 2 - 7 } coleta & P1 & P2 & LC1 & LC2 & LC3 & LNC4 \\
\hline $20 / 8$ & 79,26 & 73,50 & 47,94 & 53,05 & 54,97 & 51,13 \\
$8 / 9$ & 61,36 & 130,39 & 99,71 & 94,60 & 106,10 & 109,93 \\
$21 / 9$ & 147,10 & 131,70 & 131,70 & 89,70 & 140,10 & 151,30 \\
$6 / 10$ & 114,90 & 89,70 & 170,90 & 126,10 & 142,90 & 155,50 \\
$21 / 10$ & 20,80 & 117,80 & 101,30 & 124,00 & 103,40 & 80,60 \\
$5 / 11$ & 142,60 & 142,60 & 93,00 & 121,90 & 74,50 & 91,00 \\
$20 / 11$ & 214,82 & 169,41 & 121,93 & 194,18 & 165,28 & 128,12 \\
$7 / 12$ & 173,53 & 185,92 & 152,89 & 264,36 & 185,92 & 165,28 \\
\hline Média & 119,30 & 130,13 & 114,92 & 133,49 & 121,65 & 116,61 \\
DP & 63,32 & 37,43 & 38,34 & 66,54 & 44,83 & 40,54 \\
CV $(\%)$ & 53,07 & 28,76 & 33,36 & 49,85 & 36,86 & 34,76 \\
p & & \multicolumn{7}{c}{0,9683} & & \\
\hline
\end{tabular}

DP: Desvio Padrão, em mg L ${ }^{-1}$; CV: Coeficiente de variação (\%); P1: Esgoto bruto; P2: Saída do tanque séptico 3; LC1: Leito de cultivo 1 (Taboa); LC2: Leito de cultivo 2 (Papiro brasileiro); LC3: Leito de cultivo 3 (Lírio do brejo); LNC4: Leito de cultivo 4 (sem planta);

Não houve diferença estatística entre os pontos de coleta pelo teste de Duncan a 5\% de probabilidade; 


\subsubsection{Ferro Total, Ferro II e Ferro III}

O valor médio Ferro total no P1 foi 2,43 $\mathrm{mg} \mathrm{L}^{-1}$ e em P2 1,63 $\mathrm{mg} \mathrm{L}^{-1}$, enquanto que no leitos cultivos foram de $1,02 \mathrm{mg} \mathrm{L}^{-1}, 1,05 \mathrm{mg} \mathrm{L}^{-1}, 1,18 \mathrm{mg} \mathrm{L}^{-1}$, e $1,24 \mathrm{mg} \mathrm{L}^{-1}$, respectivamente, para LC1, LC2, LC3 e LNC4 (Tabela 29), ou seja, em valor absoluto foram bem menores nos leitos.

A oxidação química do ferro é condição necessária para o tratamento, uma vez que diminui a concentração solúvel do metal proporcionando sua remoção em processos que empregam separação sólido/líquido (Moruzzi et al., 2012). O ferro apresentam-se dissolvidos sob diferentes formas e dependem basicamente do $\mathrm{pH}$.

O valor médio Ferro II no P1 foi de $2,14 \mathrm{mg} \mathrm{L}^{-1}$ e P2 1,34 $\mathrm{mg} \mathrm{L}^{-1}$, enquanto que nos leitos cultivos foram de $0,63 \mathrm{mg} \mathrm{L}^{-1}, 0,72 \mathrm{mg} \mathrm{L}^{-1}, 0,79 \mathrm{mg} \mathrm{L}^{-1}$, e $0,82 \mathrm{mg} \mathrm{L}^{-1}$, respectivamente, para LC1, LC2, LC3 e LNC4 (Tabela 30), então, a exemplo do ferro total, em valor absoluto foram bem menores nos leitos, portanto, nos tanques sépticos houve elevação de ferro II e redução nos leitos.

TABELA 29. Valores de ferro total, em $\mathrm{mg} \mathrm{L}^{-1}$, desvio padrão, coeficiente de variação, teste de comparação de médias e eficiência total entre a entrada (P1) e saída dos tanques sépticos (P2) e entre a entrada (P2) e saída dos leitos cultivados (LC1, LC2, LC3 e LNC4), para diferentes datas de coleta e diferentes datas do ano de 2015

\begin{tabular}{ccccccc}
\hline \multirow{2}{*}{$\begin{array}{c}\text { Datas de } \\
\text { coleta }\end{array}$} & P1 & P2 & LC1 & LC2 & LC3 & LNC4 \\
\cline { 2 - 7 } $20 / 8$ & 1,589 & 1,112 & 0,740 & 0,380 & 0,677 & 0,549 \\
$8 / 9$ & 1,576 & 1,538 & 1,271 & 1,080 & 1,617 & 1,100 \\
$21 / 9$ & 2,979 & 1,696 & 1,090 & 0,788 & 0,853 & 1,466 \\
$6 / 10$ & 0,686 & 1,257 & 1,537 & 0,801 & 1,990 & 2,394 \\
$21 / 10$ & 3,597 & 1,668 & 0,676 & 1,107 & 0,891 & 1,335 \\
$5 / 11$ & 3,463 & 2,067 & 0,515 & 0,842 & 0,704 & 1,007 \\
$20 / 11$ & 2,431 & 1,843 & 0,861 & 1,776 & 1,084 & 1,171 \\
$7 / 12$ & 3,156 & 1,869 & 1,455 & 1,664 & 1,656 & 0,925 \\
\hline Média & 2,43 & 1,63 & 1,02 & 1,05 & 1,18 & 1,24 \\
DP & 1,05 & 0,32 & 0,38 & 0,47 & 0,50 & 0,54 \\
CV(\%) & 43,18 & 19,59 & 37,15 & 44,34 & 42,26 & 43,49 \\
& & & & &
\end{tabular}

$\mathrm{p}<0,0001$

DP: Desvio Padrão, em mg L ${ }^{-1}$; CV: Coeficiente de variação (\%); P1: Esgoto bruto; P2: Saída do tanque séptico 3; LC1: Leito de cultivo 1 (Taboa); LC2: Leito de cultivo 2 (Papiro brasileiro); LC3: Leito de cultivo 3 (Lírio do brejo); LNC4: Leito de cultivo 4 (sem planta);

Não houve diferença estatística entre os pontos de coleta pelo teste de Duncan a 5\% de probabilidade; 
TABELA 30. Valores de ferro II, em $\mathrm{mg} \mathrm{L}^{-1}$, desvio padrão, coeficiente de variação, teste de comparação de médias e eficiência total entre a entrada (P1) e saída dos tanques sépticos (P2) e entre a entrada (P2) e saída dos leitos cultivados (LC1, LC2, LC3 e LNC4), para diferentes datas de coleta e diferentes datas do ano de 2015

\begin{tabular}{ccccccc}
\hline \multirow{2}{*}{$\begin{array}{c}\text { Datas de } \\
\text { coleta }\end{array}$} & P1 & P2 & LC1 & LC2 & LC3 & LNC4 \\
\hline \cline { 2 - 7 } $20 / 8$ & 0,322 & 0,938 & 0,584 & 0,341 & 0,495 & 0,505 \\
$8 / 9$ & 1,534 & 1,227 & 0,866 & 0,824 & 1,272 & 0,749 \\
$21 / 9$ & 2,979 & 1,455 & 0,452 & 0,361 & 0,462 & 1,054 \\
$6 / 10$ & 0,512 & 1,057 & 0,770 & 0,415 & 1,328 & 1,499 \\
$21 / 10$ & 3,357 & 1,395 & 0,445 & 0,764 & 0,746 & 1,038 \\
$5 / 11$ & 3,230 & 1,793 & 0,284 & 0,600 & 0,576 & 0,749 \\
$20 / 11$ & 2,279 & 1,496 & 0,638 & 1,215 & 0,536 & 0,650 \\
$7 / 12$ & 2,920 & 1,394 & 1,025 & 1,247 & 0,879 & 0,344 \\
\hline Média & 2,14 & 1,34 & 0,63 & 0,72 & 0,79 & 0,82 \\
DP & 1,21 & 0,27 & 0,24 & 0,36 & 0,35 & 0,36 \\
CV(\%) & 56,71 & 19,94 & 38,65 & 50,17 & 43,94 & 44,21 \\
p & & \multicolumn{7}{c}{$<0,0001$} & & \\
\hline
\end{tabular}

DP: Desvio Padrão, em mg L ${ }^{-1}$; CV: Coeficiente de variação (\%); P1: Esgoto bruto; P2: Saída do tanque séptico 3; LC1: Leito de cultivo 1 (Taboa); LC2: (Papiro brasileiro); LC3: (Lírio do brejo); LNC4: sem planta;

Não houve diferença estatística entre os pontos de coleta pelo teste de Duncan a 5\% de probabilidade;

$\mathrm{O}$ valor de ferro III no P1(efluente bruto) variou de 0 a 1,267 entre os dias das coletas, devido a variação do tipo de esgoto gerado e valor médio de $0,29 \mathrm{mg} \mathrm{L}^{-1}$ para P1 e P2. Nos leitos de cultivos foram de $0,39 \mathrm{mg} \mathrm{L}^{-1}, 0,33 \mathrm{mg} \mathrm{L}^{-1}, 0,40 \mathrm{mg} \mathrm{L}^{-1}$, e 0,42 $\mathrm{mg} \mathrm{L}^{-1}$, respectivamente, para LC1, LC2, LC3 e LNC4 (Tabela 31), ou seja, ao contrário do ferro total e ferro II, houve elevação na saída dos leitos em relação aos tanques sépticos. 
TABELA 31. Valores de ferro III, em $\mathrm{mg} \mathrm{L}^{-1}$, desvio padrão, coeficiente de variação, teste de comparação de médias e eficiência total entre a entrada (P1) e saída dos tanques sépticos (P2) e entre a entrada (P2) e saída dos leitos cultivados (LC1, LC2, LC3 e LNC4), para diferentes datas de coleta, para diferentes datas do ano de 2015

\begin{tabular}{ccccccc}
\hline \multirow{2}{*}{$\begin{array}{c}\text { Datas de } \\
\text { coleta }\end{array}$} & P1 & P2 & LC1 & LC2 & LC3 & LNC4 \\
\cline { 2 - 7 } $20 / 8$ & 1,267 & 0,174 & 0,156 & 0,039 & 0,182 & 0,044 \\
$8 / 9$ & 0,042 & 0,311 & 0,405 & 0,256 & 0,345 & 0,351 \\
$21 / 9$ & 0 & 0,241 & 0,638 & 0,427 & 0,391 & 0,412 \\
$6 / 10$ & 0,174 & 0,200 & 0,767 & 0,386 & 0,662 & 0,895 \\
$21 / 10$ & 0,240 & 0,273 & 0,231 & 0,343 & 0,145 & 0,297 \\
$5 / 11$ & 0,233 & 0,274 & 0,231 & 0,242 & 0,128 & 0,258 \\
$20 / 11$ & 0,152 & 0,347 & 0,223 & 0,561 & 0,548 & 0,521 \\
$7 / 12$ & 0,236 & 0,475 & 0,43 & 0,417 & 0,777 & 0,581 \\
\hline Média & 0,29 & 0,29 & 0,39 & 0,33 & 0,40 & 0,42 \\
DP & 0,40 & 0,09 & 0,22 & 0,16 & 0,25 & 0,25 \\
CV $(\%)$ & 137,81 & 32,90 & 57,10 & 46,87 & 61,83 & 60,34 \\
p & \multicolumn{7}{c}{0,8386} & & \\
\hline DP: Des & & & & & \\
\hline
\end{tabular}

DP: Desvio Padrão, em mg L ${ }^{-1}$; CV: Coeficiente de variação (\%); P1: Esgoto bruto; P2: Saída do tanque séptico 3; LC1: Leito de cultivo 1 (Taboa); LC2: Leito de cultivo 2 (Papiro brasileiro); LC3: Leito de cultivo 3 (Lírio do brejo); LNC4: Leito de cultivo 4 (sem planta);

Não houve diferença estatística entre os pontos de coleta pelo teste de Duncan a 5\% de probabilidade;

\subsubsection{Coliformes Totais (CT) e E. coli}

No P1 o valor de CT variou de 10.000 a 24.196.000 NMP $100 \mathrm{~mL}^{-1}$ e valor médio de 6.123.250 NMP $100 \mathrm{~mL}^{-1}$ e de 1.303.325 NMP $100 \mathrm{~mL}^{-1}$ para $\mathrm{P} 2,98.037,50$ NMP $100 \mathrm{~mL}^{-1}$ na saída do LC1, 94.325 NMP $100 \mathrm{~mL}^{-1}$ no LC2, $116.225 \mathrm{NMP} 100 \mathrm{~mL}^{-}$ ${ }^{1}$ no LC3 e 79.162,50 NMP $100 \mathrm{~mL}^{-1}$ no LNC4 (Tabela 32).

As bactérias do grupo coliforme habitam normalmente o intestino de homens e animais, servindo, portanto como indicadoras da contaminação de uma água por fezes. Tendo em vista que a maior parte das doenças associadas com a água é transmitida por via fecal, os organismos patogênicos são eliminados pelas fezes, atingem o ambiente aquático e voltam a contaminar pessoas que abastecem indevidamente desta água. Quanto maior a população de coliformes em amostra de água, maior é a chance de que haja contaminação por organismos patogênicos.

Observa-se elevação dos CT em P2 em relação a P1 nas três primeiras datas de análise e redução nas quatro últimas datas, possivelmente pela melhora na estabilização dos tanques sépticos, sendo estes valores de acordo com as afirmativas de Von SPERLING (2005), que ressalta a eficiência moderada na remoção de CT em TS, necessitando de um pós-tratamento, segundo o mesmo autor, mostra que no tratamento 
primário a concentração de coliforme termotolerante deve ficar entre 30 a $40 \%$ para ser considerado eficiente.

TABELA 32. Valores de coliformes totais (CT), em NMP $100 \mathrm{~mL}^{-1}$, desvio padrão, coeficiente de variação, para diferentes datas do ano de 2015.

\begin{tabular}{ccccccc}
\hline Datas de & \multicolumn{7}{c}{ Pontos de coleta } \\
\cline { 2 - 7 } coleta & P1 & P2 & LC1 & LC2 & LC3 & LNC4 \\
\hline $20 / 8$ & 10000 & 41000 & - & - & - & - \\
$8 / 9$ & 309000 & 487000 & 46400 & 11500 & 123900 & 102500 \\
$21 / 9$ & 20000 & 216000 & 39300 & 3100 & 12100 & 4100 \\
$6 / 10$ & - & 83600 & 7500 & - & 2000 & 1000 \\
$21 / 10$ & 24196000 & 6294000 & 344800 & 435200 & 228200 & 209800 \\
$5 / 11$ & 52000 & 20000 & 18700 & 51300 & 10900 & 78000 \\
$20 / 11$ & 24196000 & 3255000 & 275500 & 224700 & 547500 & 235900 \\
$7 / 12$ & 203000 & 30000 & 52100 & 28800 & 5200 & 2000 \\
\hline Média & 6123250,00 & 1303325,00 & 98037,50 & 94325,00 & 116225,00 & 79162,50 \\
DP & 11155262,70 & 2296394,92 & 133477,81 & 156896,00 & 192507,13 & 97206,19 \\
CV(\%) & 182,18 & 176,20 & 136,15 & 166,34 & 165,63 & 122,79 \\
\hline
\end{tabular}

DP: Desvio Padrão, em mg L ${ }^{-1}$; CV: Coeficiente de variação (\%); P1: Esgoto bruto; P2: Saída do tanque séptico 3; LC1: Leito de cultivo 1 (Taboa); LC2: Leito de cultivo 2 (Papiro brasileiro); LC3: Leito de cultivo 3 (Lírio do brejo); LNC4: Leito de cultivo 4 (sem planta).

Nos LC'S as eficiências médias de remoção de coliformes totais (CT), foram de $60,3 \%, 53,7 \%, 84,3 \%$ e 46,3\% nos LC1, LC2, LC3, e LNC4, respectivamente (Tabela 33).

TABELA 33. Eficiência de remoção de coliformes totais (CT), desvio padrão, coeficiente de variação, médias no $\mathrm{P} 1$, tanques sépticos $(\mathrm{P} 2)$ e na saída dos leitos cultivados (LC1, LC2, LC3 e LNC4), para diferentes datas do ano de 2015

\begin{tabular}{|c|c|c|c|c|c|}
\hline \multirow{2}{*}{$\begin{array}{c}\text { Datas de } \\
\text { coleta }\end{array}$} & \multicolumn{5}{|c|}{ Eficiências (\%) } \\
\hline & E.T.S. & $\mathrm{LC} 1$ & LC2 & LC3 & LNC4 \\
\hline $20 / 8$ & -310 & 100 & 100 & 100 & 100 \\
\hline $8 / 9$ & -58 & 90 & 97 & 74 & 79 \\
\hline $21 / 9$ & -980 & 81 & 99 & 94 & 98 \\
\hline $6 / 10$ & - & 91 & 100 & 97 & 98 \\
\hline $21 / 10$ & 74 & 94 & 93 & 96 & 97 \\
\hline $5 / 11$ & 62 & 7 & -156 & 45 & -290 \\
\hline $20 / 11$ & 87 & 92 & 93 & 83 & 93 \\
\hline $7 / 12$ & 85 & -74 & 4 & 83 & 93 \\
\hline Média & -130 & 60 & 54 & 84 & 46 \\
\hline DP & 368 & 62 & 91 & 18 & 136 \\
\hline $\mathrm{CV}(\%)$ & -283 & 103 & 169 & 21 & 295 \\
\hline $\mathrm{p}$ & & & & & \\
\hline
\end{tabular}

DP: Desvio Padrão, em mg L ${ }^{-1}$; CV: Coeficiente de variação (\%); P1: Esgoto bruto; P2: Saída do tanque séptico 3; LC1: Leito de cultivo 1 (Taboa); LC2: Leito de cultivo 2 (Papiro brasileiro); LC3: Leito de cultivo 3 (Lírio do brejo); LNC4: Leito de cultivo 4 (sem planta);

Não houve diferença estatística entre os pontos de coleta pelo teste de Duncan a 5\% de probabilidade; 
O valor médio de E. coli para P1 foi de $1.548 .500 \mathrm{NMP} 100 \mathrm{~mL}^{-1}$ e de 42.900 NMP $100 \mathrm{~mL}^{-1}$ para P2. Nos LC's os valores foram de $1.275 \mathrm{NMP} 100 \mathrm{~mL}^{-1}$ no LC1, $500 \mathrm{NMP} 100 \mathrm{~mL}^{-1}$ no LC2, $1.425 \mathrm{NMP} 100 \mathrm{~mL}^{-1}$ no LC3 e $1,437 \mathrm{NMP} 100 \mathrm{~mL}^{-1}$ para o LNC4, mostrando diminuição desde o esgoto bruto (P1) até a saída dos leitos cultivos, sendo mais expressivo no LC2 ( papiro-brasileiro) (Tabela 34).

TABELA 34. Valores de E. coli, em NMP $100 \mathrm{~mL}^{-1}$, desvio padrão, coeficiente de variação, médias de Esgoto bruto (P1) tanques sépticos (P2) e na saída dos leitos cultivados (LC1, LC2, LC3 e LNC4), para diferentes datas de análise do ano de 2015.

\begin{tabular}{ccccccc}
\hline Datas de & \multicolumn{7}{c}{ Pontos de coleta } \\
\cline { 2 - 7 } coleta & P1 & P2 & LC1 & LC2 & LC3 & LNC4 \\
\hline $20 / 8$ & 10.000 & - & - & - & - & - \\
$8 / 9$ & 20.000 & 75.000 & 2.000 & - & 8.400 & 7.500 \\
$21 / 9$ & - & 10.000 & - & - & - & - \\
$6 / 10$ & - & 26.200 & 1.000 & - & - & - \\
$21 / 10$ & 12.033 .000 & 18.1000 & 5.200 & 2.000 & 2.000 & 1.000 \\
$5 / 11$ & - & - & 2.000 & 1.000 & - & 1.000 \\
$20 / 11$ & 273.000 & 31.000 & - & - & 1.000 & 2.000 \\
$7 / 12$ & 52.000 & 20.000 & - & 1.000 & - & - \\
\hline Média & 1548500 & 42900 & 1275 & 500 & 1425 & 1437 \\
DP & 4237385 & 60722 & 1814 & 755 & 2910 & 2555 \\
CV $(\%)$ & 273 & 141 & 142 & 151 & 204 & 177 \\
\hline
\end{tabular}

DP: Desvio Padrão, em mg L ${ }^{-1}$; CV: Coeficiente de variação (\%); P1: Esgoto bruto; P2: Saída do tanque séptico 3; LC1: Leito de cultivo 1 (Taboa); LC2: Leito de cultivo 2 (Papiro brasileiro); LC3: Leito de cultivo 3 (Lírio do brejo); LNC4: Leito de cultivo 4 (sem planta);

Não houve diferença estatística entre os pontos de coleta pelo teste de Duncan a 5\% de probabilidade;

- Analise não efetuada

A E.T.S mostrou-se eficiente na remoção de E. coli, com valor de $61,5 \%$, já para os LC'S as médias de remoção forma maiores, ou seja, 73,8\%, 74,2\%, 73,1\% e 72,9 para os LC1, LC2, LC3 e LNC4, respectivamente (Tabela 35).

A contribuição do esgoto não pode elevar a contagem de coliformes termotolerantes nos corpos receptores acima de $1.000 \mathrm{NMP} 100 \mathrm{~mL}^{-1}$ e não deverá ser excedido um limite de 1.000 NMP $100 \mathrm{~mL}^{-1}$ coliformes termotolerantes em $80 \%$ ou mais de pelo menos seis amostras coletadas durante o período de um ano, com frequência bimestral, em corpos receptores de classe 2, conforme padrões de lançamento da Resolução CONAMA n.430 (BRASIL, 2011). 
TABELA 35. Eficiência de remoção de E. coli desvio padrão, coeficiente de variação, médias no P1, tanques sépticos (P2) e na saída dos leitos cultivados (LC1, LC2, LC3 e LNC4), para diferentes datas do ano de 2015.

\begin{tabular}{cccccc}
\hline Datas de & \multicolumn{5}{c}{ Eficiências (\%) } \\
\cline { 2 - 6 } coleta & E.T.S. & LC1 & LC2 & LC3 & LNC4 \\
\hline $20 / 8$ & 100 & - & - & - & - \\
$8 / 9$ & -275 & 97 & 100 & 898 & 90 \\
$21 / 9$ & - & 100 & 100 & 100 & 100 \\
$6 / 10$ & - & 96 & 100 & 100 & 100 \\
$21 / 10$ & 98 & 97 & 99 & 99 & 99 \\
$5 / 11$ & - & - & 0 & 0 & 0 \\
$20 / 11$ & 88 & 100 & 100 & 97 & 93 \\
$7 / 12$ & 61,5 & 100 & 95 & 100 & 100 \\
\hline Média & 9 & 74 & 74 & 73 & 73 \\
DP & 123 & 45 & 46 & 45 & 45 \\
CV $(\%)$ & 1338 & 62 & 62 & 62 & 62 \\
\hline
\end{tabular}

DP: Desvio Padrão, em mg L ${ }^{-1}$; CV: Coeficiente de variação (\%); P1: Esgoto bruto; P2: Saída do tanque séptico 3; LC1: Leito de cultivo 1 (Taboa); LC2: Leito de cultivo 2 (Papiro brasileiro); LC3: Leito de cultivo 3 (Lírio do brejo); LNC4: Leito de cultivo 4 (sem planta); E.T.S. Eficiência dos tanques sépticos (P1 a P2).

A resolução determina padrões para amostras coletados em corpos hídricos, o que não é o caso deste trabalho. Ou seja, o grau de contaminação depende, além do NMP de coliformes no efluente, do grau de diluição no corpo hídrico receptor.

\subsection{Adaptação e desenvolvimento das macrofitas}

Na data de 06 de outubro de 2015 houve a reposição de 6 mudas de taboa (LC1), 30 mudas de papiro-brasileiro (LC2) e 32 mudas de Lírio do brejo (LC3). No dia 20 de novembro de 2015 também foram replantadas mais 13 mudas de papiro-brasileiro (LC2). As mortes das plantas ocorreram mais intensamente próximas à entrada do efluente nos leitos, (Figuras 15 e 16), que também apresentaram menor desenvolvimento, onde se acredita que se deve ao uso de sanitizante aplicado na limpeza do refeitório. Nos três primeiros meses após o transplantio das mudas de macrofitas para os leitos, o desenvolvimento foi muito lento, porém a partir deste período, com o aprofundamento do sistema radicular e especialmente com o início das chuvas, o desenvolvimento das plantas foi mais acelerado, mas sempre com grande diferença no crescimento das plantas entre a entrada e saídas dos leitos, sendo muito mais evidente este efeito para a Taboa e o lírio do brejo. Para o papiro brasileiro, por sua vez, a diferença no desenvolvimento das plantas não foi tão evidente quanto às 
outras espécies, demonstrando ser a que melhor se adaptou nas condições do experimento (Figura 15).

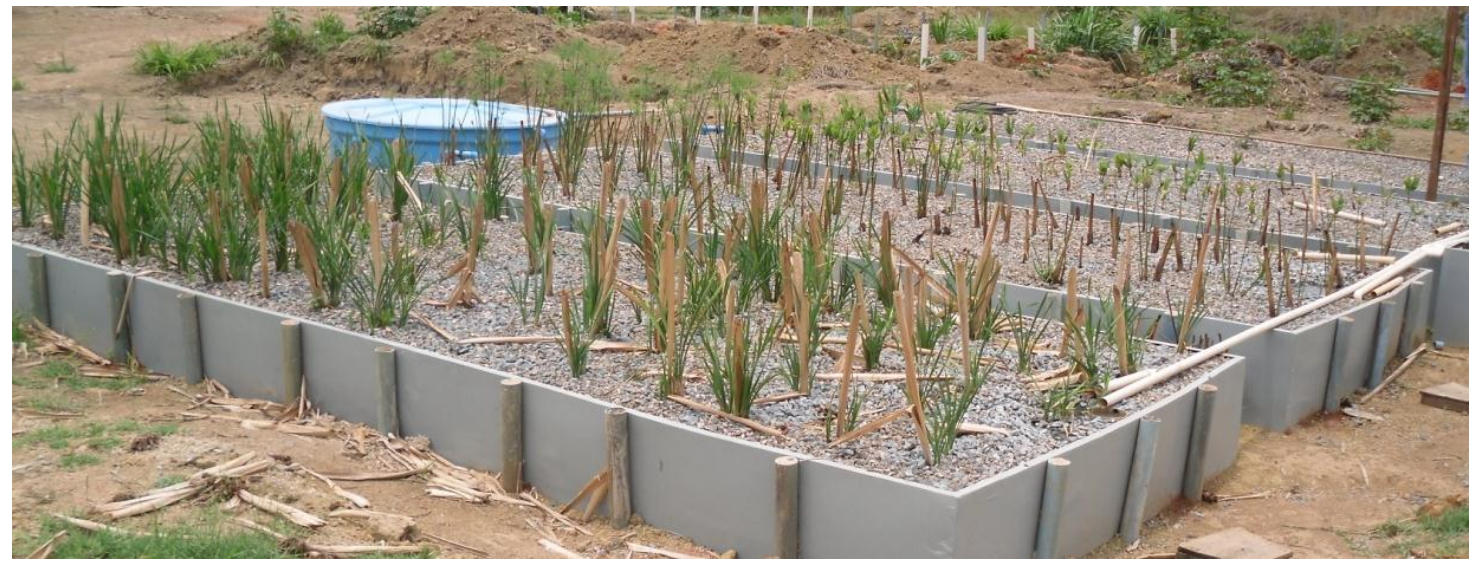

FIGURA 15. Leitos de cultivos no inicio do desenvolvimento vegetal - outubro/2015.

Na Figura 16 observam-se as plantas no início do leito com taboa com sintomas de secamento, que é devido ao rebaixamento do nível do efluente nos leitos, já que parte do mês de dezembro de 2015 e janeiro de 2016, que não foi gerado esgoto. Como as plantas na entrada do leito tem sistema radicular menos desenvolvido (mais superficial), estas estão mais sujeitos ao estresse hídrico quando do rebaixamento do nível do efluente no leito.

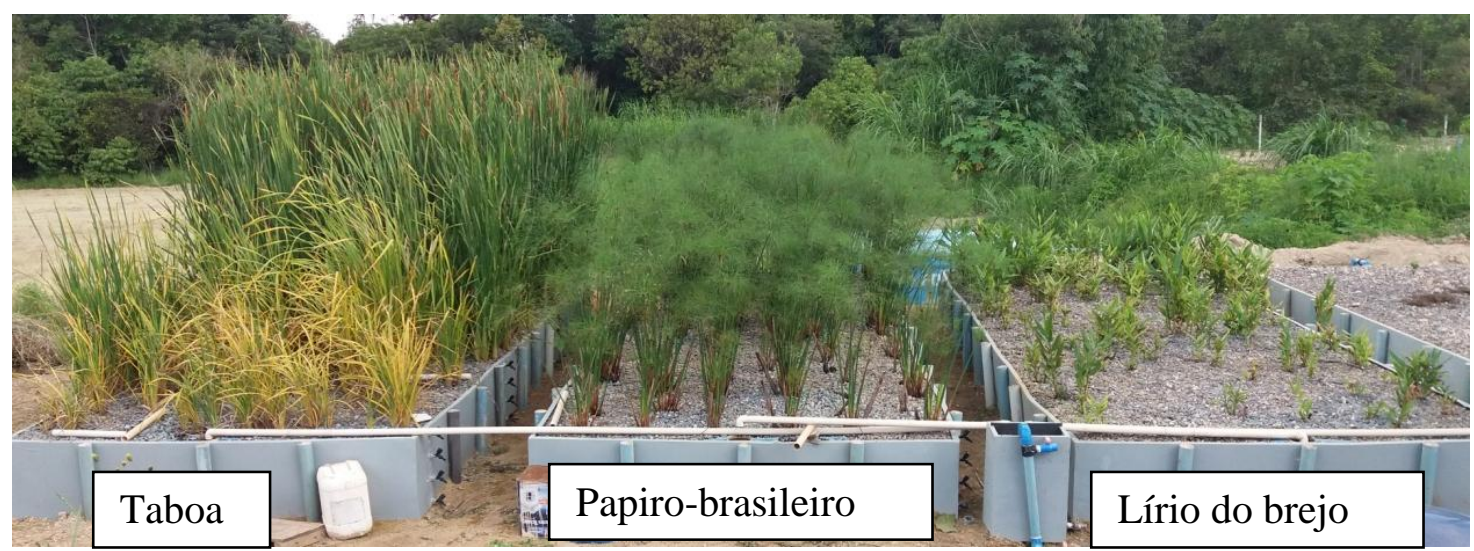

FIGURA 16. Leitos de cultivos após 6 meses do tansplantio, janeiro/2016.

Quanto ao manejo adotado para as macrófitas, não foi realizado nenhum corte ou remoção de folhas que secaram, nem a aplicação de qualquer tipo de substância química, pelo fato da ETE estar em funcionamento a poucos meses, de forma que as plantas estão em pleno desenvolvimento, não apresentando, ainda, sinais de estágio de maturação e os leitos ainda não estavam completamente ocupados pelas plantas.

A Figura 17 apresenta o desenvolvimento da macrófita taboa (leito de cultivo 1). Como pode ser observado o crescimento da taboa nos três (3) primeiros meses de após o transplantio foram lento, tendo um melhor desempenho no bloco 4 . 
As alturas das plantas de taboa variaram entre as datas de medida, passando de média de 42,3 cm, em 05/11/15 para 93,95 $\mathrm{cm}$ em 27/01/16. A altura também variou muito entres os blocos, sendo que a altura das plantas, no bloco1 (plantas 1 a 24) foi de 94,0 cm, já no bloco 4 foi de 216,7 cm na data de 27/01/16 (Figura 17 ).

A maior variação de crescimento entre as plantas de taboa ocorreram no bloco 3 (plantas de 49 a 73), com variação de 144,3 cm entre os dias 05/11/15 a 27/01/2016.

Nos meses de dezembro de 2015 e janeiro de 2016 ocorreu crescimento continuo em todos os blocos para macrófita taboa, porem não igualitário, sendo mais expressivo no bloco 4 .

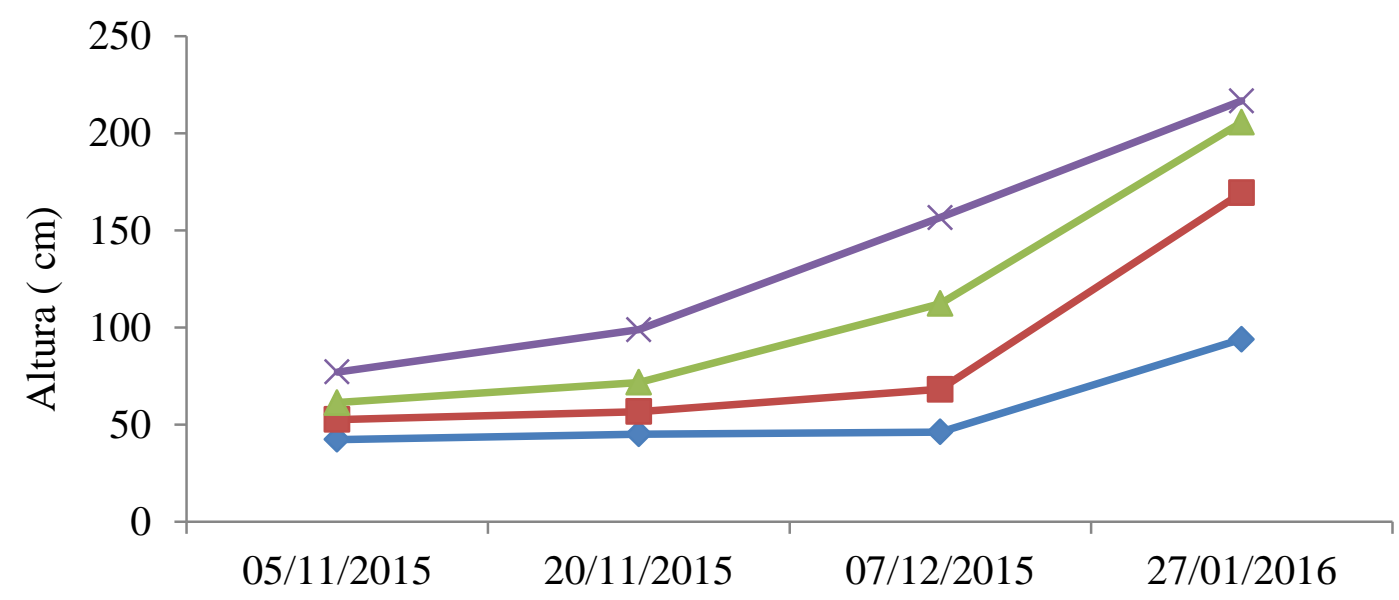

Datas de medidas

$\neg$ Bloco $1 \leftarrow$ Bloco $2 \leftarrow$ Bloco $3 \leftarrow$ Bloco 4

FIGURA 17. Altura da Taboa (cm), entre outubro de 2015 e janeiro de 2016.

A Figura 18 apresenta o desenvolvimento da macrófita papiro-brasileiro (LC2) entre as datas 21/10/15 a 27/01/16. Sendo que a maior variação de crescimento dessa macrofita ocorreu no bloco 4, apresentando 70,1 cm de altura entre essas datas. Pode se observar que nos meses de dezembro de 2015 e janeiro de 2016 ocorreu crescimento continuo em todos os blocos, porem não igualitário. 


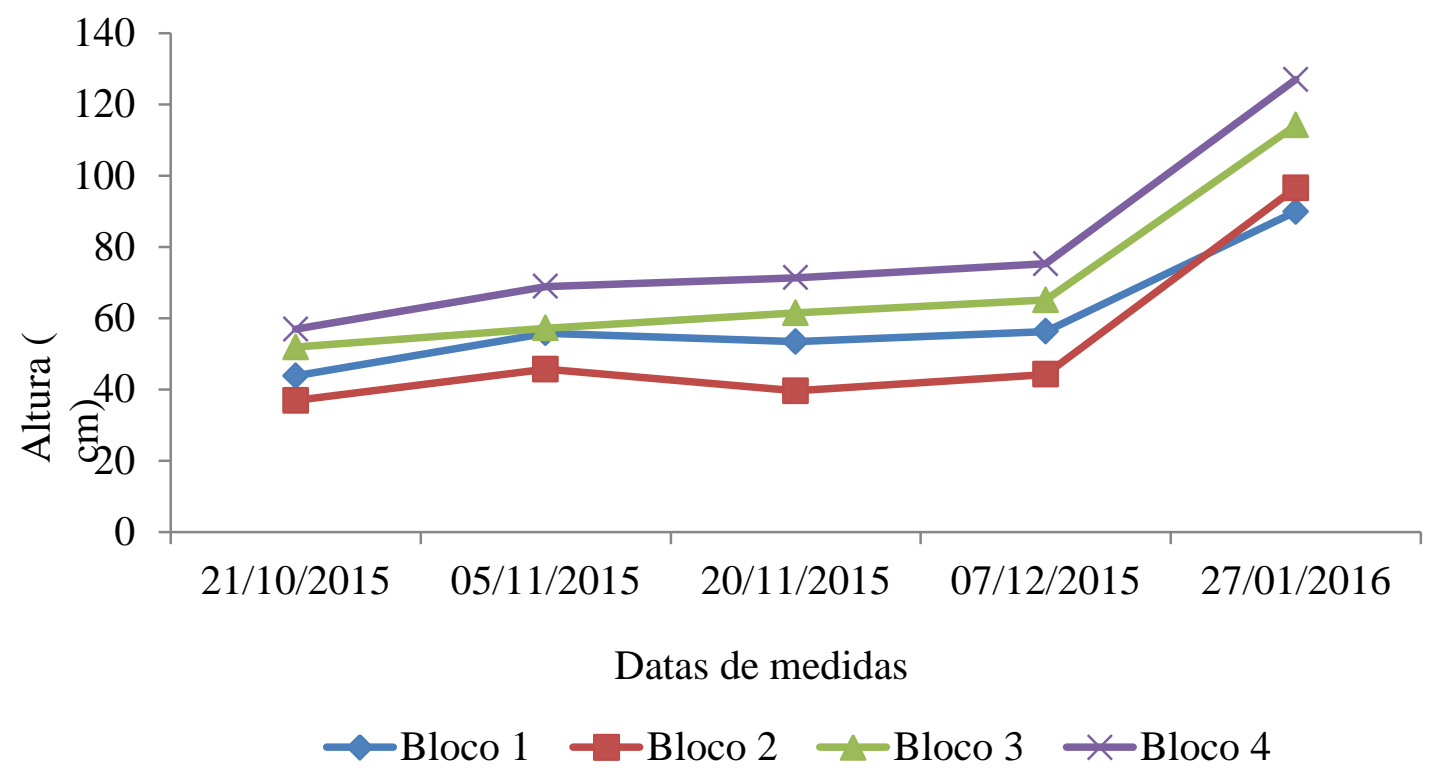

FIGURA 18. Altura do Papiro-brasileiro (cm), entre outubro de 2015 e janeiro de 2016.

A maior variação de altura da espécie lírio do brejo, ocorreu bloco 4, que foi de 22,1 cm (Figura 19 ) entre as datas de 21/10/15 a 27/01/16. No bloco 1 (entrada do leito), pode observa o decaimento no crescimento dessa macrófitas, devido a mortes no inicio do leito.

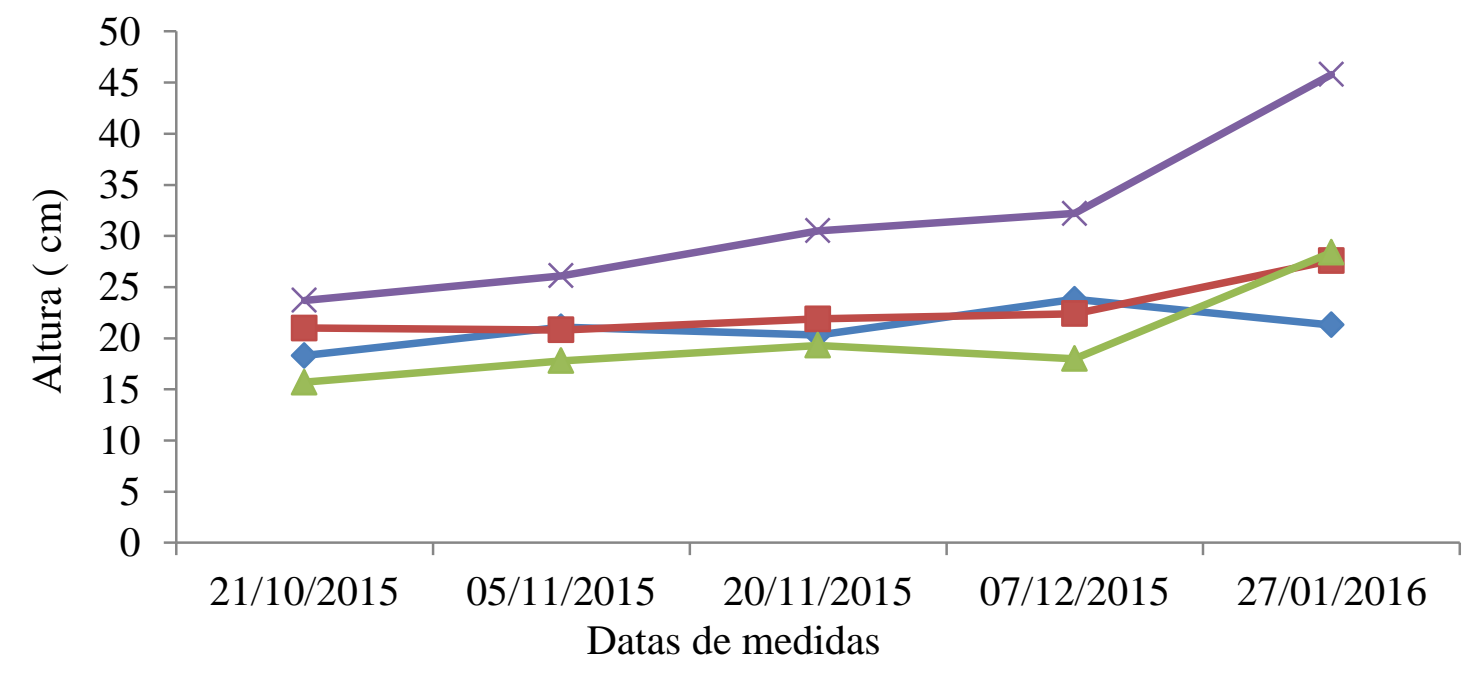

$\neg$ Bloco $1 \multimap$ Bloco $2 \leftarrow$ Bloco $3 \leftarrow$ Bloco 4

FIGURA 19. Altura do Lírio do brejo (cm), entre outubro de 2015 e janeiro de 2016.

A Figura 20 apresenta o desenvolvimento total das macrófitas durante os seis (6) meses de projeto, sendo que a altura foi medida a partir do dia 21/10/15 até o dia 27/01/16. Das espécies de macrófitas estudadas nesse projeto, o lírio do brejo (LC3), 
apresentou a menor variação de altura entre os blocos. O LC1 (taboa) apresentou maior diferença de altura entre os blocos, principalmente entre o bloco 1 e bloco 4.

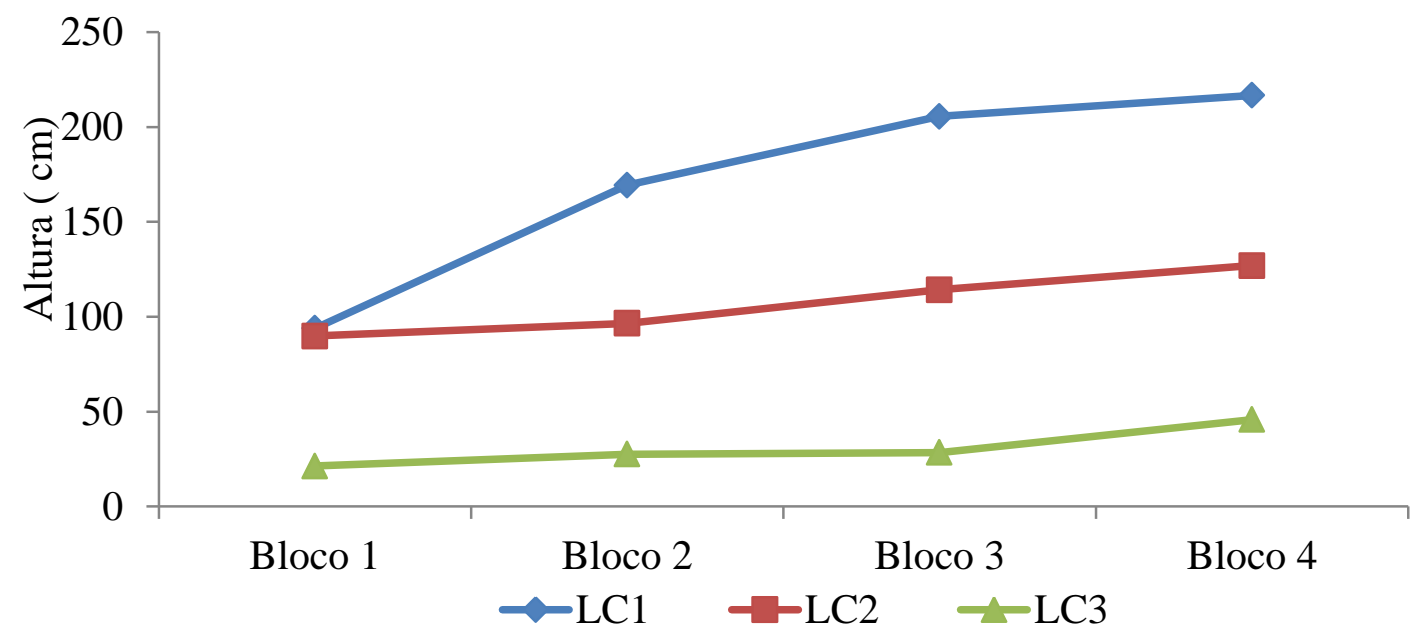

FIGURA 20. Crescimento total das macrofitas nos bloco (cm) - 27 de Janeiro /2016; LC1 (Taboa), LC2 (Papiro-brasileiro) LC3 (lírio do brejo).

\section{CONCLUSÕES}

Os três tanques sépticos em série, de maneira geral, apresentam maior capacidade de redução da turbidez $(12,4 \%)$, sólidos suspensos totais (28\%), nitrato $(15,7 \%)$, nitrito (20\%), amônia $(28,5 \%)$ e E. coli $(9 \%)$.

Alguns parâmetros analisados nos pontos de coletas (P1, P2, LC'S e LNC) apresentaram pouca variação nos resultados, sendo que a temperatura foi, em média, de $30^{\circ} \mathrm{C}$, já pH variou de 5,70 a 7,42 .

De modo geral, a tendência no leito cultivado com taboa é apresentar maior capacidade de redução nas concentrações de sólidos suspensos totais $(58,6 \%)$, sólidos totais $(11,2 \%)$, DBO $(99,99 \%)$, com valores de sódio na saída do leito de 114,92 mg L-1, $0,72 \mathrm{mg} \mathrm{L}^{-1}$ de ferro II, $908,78 \mu \mathrm{S} \mathrm{cm}^{-1}$ de condutividade elétrica; por sua vez, o leito cultivado com papiro brasileiro reduziu a DBO (94,5\%), DQO $(60,5 \%)$, com valor de ferro total na saída do leito de $0,63 \mathrm{mg} \mathrm{L}^{-1}$, coliforme totais de $94.325 \mathrm{NMP} 100 \mathrm{~mL}^{-1} \mathrm{e}$ potássio de $46,31 \mathrm{mg} \mathrm{L}^{-1}$; já o leito cultivado com lírio do brejo, a redução de DQO foi $71,6 \%$, DBO de $99,1 \%$, nitrato de $88,1 \%$ e nitrito de $83,6 \%$.

O desenvolvimento das três espécies de plantas aquáticas não é uniforme no interior dos leitos cultivados, com crescimento aumentando da entrada em direção à saída dos mesmos. 


\section{REFERÊNCIAS}

AKRATOS, C.; TSIHRINTZIS, V., Effect of temperature, HRT, vegetation and porous media on removal efficiency of pilot-scale horizontal subsurface flow constructed wetlands. Ecological Engineering, 29 (2), 173-191, 2007.

ALMEIDA, R.A.; ALMEIDA, N.A.M. Remoção de coliformes do esgoto por meio de espécies vegetais. Revista Eletrônica de Enfermagem, v.7, n.3, p.308-17, 2005.

ALMEIDA, R. A.; UCKER, F. Considerando a evapotranspiração no cálculo de eficiência de estações de tratamento de esgoto com plantas. Engenharia Ambiental, v. 8, n. 4, p. 39-45, 2011.

ALMEIDA, R.A; PITALUGA, D. P. S; REIS, R. P; Tratamento de esgoto doméstico por zona de raízes precedida de tanque séptico. REVISTA BIOCIÊNCIAS, UNITAU. Volume 16, número 1, 2010. Disponível em periodicos.unitau.br

ALTVATER, P. K. Avaliação do desempenho de um tanque séptico modificado e tratamento complementar. 2008. 95p. Dissertação (Mestrado em Engenharia de Recursos Hídricos e Ambiental) - Universidade Federal do Paraná, Curitiba.

ALTVATER, P. K.; SANTOS, D. C.; MANNICH, M. Sistema biológico alternativo para pós-tratamento de esgoto. Revista DAE, n. 181, p. 23-32, 2009.

APHA; AWWA; WPCF. Standard methods for the examination of water and wastewater. $21^{\mathrm{a}}$ ed., Washington D.C., USA, American Public Health Association, 2005.

ASSUMPÇÃO, J. G.; UENO, M.; FORTES NETO, P.; ROSA, L. C. L. Desempenho do leito cultivado, de uma estação de tratamento de efluentes gerado em uma instituição de ensino, após período de inatividade. Ambi-Agua, Taubaté, v. 6, n. 3, p. 165-178, 2011. (http://dx.doi.org/10.4136/ambi-agua.499)

BORGES, A, C. Avaliação de Remoção e Transporte de Herbicida Ametrina em Sistemas Alagados Construídos. 2007. 163 f. Tese (Doutorado em Engenharia Hidráulica e Saneamento)- Escola de Engenharia de São Carlos, Universidade de São Paulo, São Carlos, 2007.

BRASIL. ABNT. Sistemas prediais de esgoto sanitário - Projeto e execução. NBR 8160. ABNT. Rio de Janeiro. 70 p. 1999.

BRASIL. ABNT. Tanques sépticos - Unidades de tratamento complementar e disposição final dos efluentes líquidos - Projeto, construção e operação. NBR 13969. ABNT. Rio de Janeiro. 60 p. 1997.

BRASIL. CONAMA. Conselho Nacional do Meio Ambiente. Ministério do Meio Ambiente. Resolução n.357 de 17 de março de 2005. Diário Oficial da União, Brasília, 2005. 23p. 
BRASIL. CONAMA. Conselho Nacional do Meio Ambiente. Ministério do Meio Ambiente. Resolução n.430 de 13 de maio de 2011. Diário Oficial da União, Brasília, 2011. 8p.

BRASIL. Constituição da República Federativa do Brasil. Brasília, Senado Federal, 1988. BRASIL. Lei $\mathbf{n}^{\mathbf{0}} \mathbf{9 . 4 3 3}$, de 9 de janeiro de 1997. Disponível em: http://www.planalto.gov.br/ccivil_03/leis/19433.htm. Acesso em: 15 nov. 2014.

BRASKERUD, B.C. Factors affecting nitrogen retention in small constructed wetlands treating agricultural non - point source pollution. Ecological Engineering, n. 18, p. 351- 370, 2002.

BRIX, H. Macrophytes play a role in constructed treatment wetlands? Water Science and Technology, v.35, p.11-17, 1997.

CAMARGO, A. P.; CAMARGO, M. B. P. Revisão analítica da evapotranspiração potencial. Bragantia, Campinas, v. 59, n. 02, p. 125-137, 2000.

CETESB. Companhia de Tecnologia de Saneamento Básico. Qualidade das águas interiores no estado de São Saulo. CETESB-COMPANHIA AMBIENTAL DO ESTADO DE SÃO PAULO. SÉRIE RELATÓRIOS. 2009.

CETESB. Companhia de Tecnologia de Saneamento Básico. Significado Ambiental Sanitário das Variáveis de Qualidade das Águas e dos Sedimentos e Metodologias Analíticas de Amostragem. São Paulo, 2008: 41 p. (Séries relatórios).

CHAGAS, R. C.; MATOS, A. T.; CECON, P. R.; MONACO, P. A. V.; FRANÇA, L. G. F. Cinética de remoção de matéria orgânica em sistemas alagados construídos cultivados com lírio amarelo. Revista Brasileira de Engenharia Agrícola e Ambiental, v. 15, n. 11, p. 1186-1192, 2011. http://dx.doi.org/10.1590/S141543662011001100012.

CHEIS, D. Remoção de nutrientes, como fósforo e nitrogênio, no tratamento de esgotos. Revista TAE. 2014. Disponível em :http://www. Revistatae .com.br /noticiaInt.asp?id=7454

CHERNICHARO, C. A.L. Reatores anaeróbios. Departamento de Engenharia Sanitária e Ambiental - UFMG, Belo Horizonte/MG, v.5, 1997.

CHERNICHARO, C. A.L. Princípios do tratamento biológico de águas residuárias: reatores anaeróbios. 2. ed. Belo Horizonte: DESA-UFMG, 2007. v.5, 379p.

COLARES, C. J. G. ; SANDRI, D. Eficiência do tratamento de esgoto com tanques sépticos seguidos de leitos cultivados com diferentes meios de suporte. Ambi-Agua, Taubaté, v. 8, n. 1, p. 172-185, 2013. (http://dx.doi.org/10.4136/ambi-agua.1047).

COLARES, C. J. G.; SANDRI, D. Tratamento de esgoto com tanques sépticos seguidos de leitos cultivados: remoção de matéria orgânica, coliformes e sólidos. N. 22 (ANO 2009): REVISTA EDUCAÇÃ̃ \& MUDANÇA - ISSN 2179-5215. 2009. 
COLLISCHONN, W. Simulação hidrológica de grandes bacias, tese de doutorado, IPH-UFRGS, 196p., 2001. IPH-UFRGS, 196p., 2001.

COSTA, J. F. Remoção de poluentes em um sistema de alagados construídos atuando como pós-tratamento de efluente de reator UASB e de filtro biológico percolador. 2013. 193p. Tese (Doutorado em Saneamento, Meio Ambiente e Recursos Hídricos), da Universidade Federal de Minas Gerais- MG.

CORDAZZO, C.V.; SEELIGER, U. Guia ilustrado da vegetação costeira do extremo sul do Brasil. Rio Grande, RS: Editora da FURG, 1988.

CRITES, R., TCHOBANOGLOUS, G. Tratamiento de aguas residuales en pequeñas poblaciones. Bogotá, Colombia: McGraw-Hill Interamericana S.A., 2000. 776 p.

CUNHA, C. A. G. Análise da eficiência de um sistema combinado de alagados construídos na melhoria da qualidade das águas. 2006. 157 p. (Mestrado em Ciências da Engenharia Ambienta) - Universidade de São Paulo, São Paulo.

ESTEVES, F. A. Fundamentos de Limnologia. 2 ed. Rio de Janeiro. Editora Interciência, 1998. 602 p.

EPA Design Manual. Municipal wastewater stabilization ponds. United States Environmental. N.?, p.?.

FACUNDO, V.A.; MOREIRA, L.S. Estudo fitoquímico e farmacológico dos constituintes fixos e voláteis de Hedychium coronarium J. Koen. (Zingiberaceae). In: CONGRESSO BRASILEIRO DE QUÍMICA, 45., 2005, Belém. Anais... Belém, Associação Brasileira de Química, 2005.

FERNANDES, C. Esgotos Sanitários, Ed. Univ./UFPB, João Pessoa - PR, 1997, 435p.

FORESTI, E.; FLORÊNCIO, L.; VAN HAANDEL, A.; ZAIAT, M.; CAVALCANTI, P.F.F. Tratamento de esgotos sanitários por processo anaeróbio e disposição controlada no solo. Fundamentos do tratamento anaeróbio. Capítulo 2. PROSAB, ABES, Rio de Janeiro, 1999.

GENEVIERE, M.C.; DUTHIE, H.C., TAYLOR, W.D. Models of aquatic plant productivity: a review of the factors that influence growth. Aquatic Botany, v.59, p.195-215, 1997.

IWA Specialist group on the use of macrophytes in water pollution control, Constructed wetlands for pollution control: processes, performance, design and operation - scientific and technical report n.8. London - UK. IWA Publishing. 2000. 156p.

JOLY, A.B. Botânica: Introdução à taxonomia vegetal. 5. ed. Companhia Editora Nacional, 1979. 777 p. 
JORDÃO, E.P.; PESSOA, C.A. Tratamento de esgotos domésticos. 5. ed. Rio de Janeiro: ABES, 2009.

JORDÃO, C. P.; RIBEIRO, P. R. da S; MATOS, A. T. de; FERNANDES, R. B. A. Aquatic contamination of the Turvo Limpo river basin at the Minas Gerais state, Brazil. Journal of the Brazilian Chemical Society, v. 18, n. 1, p.116 - 125, 2007.

KADLEC, R. H.; KNIGHT, R. L.; Treatment Wetlands. Boca Raton Lewis Publishes, 1996.

KIVAISE, A.K. 2001. The potential for constructed wetlands for wastewater treatment and reuse in developing countries: a review. Ecological Engineering. 16: 545-560.

LEITÃO, R. C.. Sedimentabilidade do lodo de reatores UASB. In: Congresso Brasileiro de Engenharia Sanitária e Ambiental, 23, 2005, Campo Grande. Anais... Rio de Janeiro: CBESA, 2005. 7 p.

LEMES,J.L.V.B; SCHIRMER W.N.; CALDEIRA M. V. W.; Kaick T. V.; ABEL O.; Bárbara, R.R. Tratamento de esgoto por meio de zona de raízes em comunidade rural. Rev. Acad., Ciênc. Agrár. Ambient., Curitiba, v. 6, n. 2, p. 169-179, abr./jun. 2008.

LIMA, S. L.; IZARIO FILHO, H. J.; CHAVES, F. J. M. Determinação de demanda bioquímica de oxigênio para teores $\leq 5$ MG. L-102. Revista Analytica, p.52-57, n.25, 2006.

LIN, Y. F, JING, S. R., LEE, D. Y., CHANG, Y. F., CHEN, Y. M., SHIH, K. C.

Performance of a constructed wetland treating intensive shrimp aquaculture wastewater under high hydraulic loading rate. Environmental Pollution, v.134, p.411-421, 2005.

MANNARINO, C. F. Wetlands para tratamento de lixiviados de aterros sanitários: experiências no aterro sanitário de Piraí e no aterro metropolitano de Gramacho (RJ). Eng. Sanit. Ambient., Jun 2006, vol.11, no.2, p.108-112. ISSN 1413-4152

MANSOR, M. T. C. Uso de leitos de macrófitas no tratamento de águas residuárias. 1998. 106p. Dissertação (Mestrado em Engenharia Agrícola) - Universidade Estadual de Campinas Campinas.

METCALF \& EDDY. Wastewater engineering: treatment, disposal and reuse. 3 ed., Metcalf \& Eddy Inc., 1991. 1334 p.

METCALF, EDDY. Wastewater Engineering: treatment, disposal and reuse. New York: McGraw-Hil, 4. ed., International Editions. 2003.

PAUL, E.A.; CLARK, F.E. Soil microbiology and biochemistry. San Diego: Academic Press, 2. ed. p.194-195, 1996.

PATRO, R. Papiro-brasileiro - Cyperus giganteus. Disponível em: http://www. jardineiro.net/br/banco/cyperus_giganteus.php. Acesso em:10/11/2014. 
PHILIPPI, L. S.; SEZERINO, P. H. Aplicação de sistemas tipo wetlands no tratamento de águas residuárias: utilização de filtros plantados com macrófitas. Florianópolis: Editora do Autor, 2004.

PLANTAS MEDICINAIS. CD-ROM, versão 1.0. PROMED - Projeto de Plantas Medicinais. EPAGRI - Empresa de Pesquisa Agropecuária e Extensão Rural de Santa Catarina S.A. Coordenação: Antônio Amaury Silva Junior. Itajaí, Santa Catarina. 2001.

PEREIRA, R. S. Identificação e caracterização das fontes de poluição em sistemas hídricos. Revista Eletrônica de Recursos Hídricos, v. 1, n. 1, p. 20 - 36, 2004.

PINTO, A. L.; OlIVEIRA, G. H.; PEREIRA, G. A. Avaliação da eficiência da utilização do oxigênio dissolvido como principal indicador da qualidade das águas superficiais da bacia do córrego Bom Jardim, BRASILÂNDIA/MS. Revista GEOMAE - Geografia, Meio Ambiente e Ensino. v.01, nº 01, 2010.

POTT, Vali J.; POTT, Arnildo. Plantas aquáticas do Pantanal. Centro de Pesquisa Agropecuária do Pantanal (Corumbá, MS). Brasília: Embrapa, Comunicação para Transferência de Tecnologia, 2000.

REDDY, K. R.; DEBUSK, W. Growth characteristics of aquatic macrophytes cultures in nutrient enriched water: I. water hyacinth, water lettuce and pennywort. Economy Botany, v.38, p.229-239, 1984.

REED, S. C.; CRITES, R. W.; MIDDLEBROOKS, E. J. Natural Systems for Waste Management and Treatment. 2. ed. McGraw Hill, 1995. 433p.

REBOUÇAS, J. R. L. et al. Crescimento do Feijão-caupi irrigado com água residuária de esgoto doméstico tratado. Revista Caatinga, Mossoró, v.23, n. 1, p. 97-102, 2010.

SANTANA, O. A.; CUNIAT, G.; ENCINAS, J. I. Contribuição da vegetação rasteira na evapotranspiração total em Diferentes ecossistemas do bioma cerrado, Distrito Federal. Ciência Florestal, Santa Maria, v. 20, n. 2, p. 269-281, abr.-jun., 2010.

SANTOS, D. C.; MAZEPA, I; KOTSUKA, L. Avaliação de Desempenho de Filtros para Tratamento de Água Cinza. In: Simpósio Nacional de Sistemas Prediais, 11, 2009, Curitiba. Anais... Curitiba: SISPRED, 2009. 2p.

SANTOS, R. J.; FORTES NETO, P.; BATISTA, G. T. Tratamento de efluentes por leito cultivado: Sistema para pequenas comunidades. Repositório Eletrônico Ciências Agrárias, Coleção Ciências Ambientais: 1-11. <http://www.agro.unitau.br/dspace>. 2011. p. 1/11.

SILVA, S.C. "Wetlands construídos" de fluxo vertical com meio de suporte de solo natural modificado no tratamento de esgotos domésticos. 2007. 205 p. Tese (Doutorado em Tecnologia Ambiental e Recurso Hídricos), Universidade de Brasília, Brasília-DF. 
SOUZA, C. F, BACICURINSKI, I.; SILVA, E. F. F. Avaliação da qualidade da água do rio Paraíba do sul no município de Taubaté-SP. Revista Biociências, UNITAU. v.16, n.1, 2010. Disponível em periodicos.unitau.br.

SPERLING, M, V. Princípios do tratamento biológico de águas residuárias. 2. ed. Belo Horizonte-MG. Departamento de Engenharia Sanitária e Ambiental - UFMG. v.1, 1996. 240p.

TONIATO, J. V. Avaliação de um Wetland construído no tratamento de efluentes sépticos: estudo de caso Ilha Grande, Rio de Janeiro, Brasil. 2005. 95f. Dissertação (Mestrado em Ciências) - Escola Nacional de Saúde Pública, Fundação Oswaldo Cruz, Rio de Janeiro, 2005.

TRUONG, P.; VAN, T. T., PINNERS, E. Vetiver system applications: technical reference manual, 2.ed. Vietnam: The Vetiver Network International, 2008.

TUNDISI, J. G. Novas perspectivas para a gestão de recursos hídricos. Revista USP, São Paulo, n.70, p. 24-35, junho/agosto 2006.

USEPA. Wastewater technology fact sheet wetlands: Subsurface flow. Washington: EPA 832-F-00-023, Office of Water, 2000. 8p.

VALENTE, J. P. S.; PADILHA, P. M.; SILVA, M.M. Oxigênio dissolvido (OD), demanda bioquímica de oxigênio (DBO) e demanda química de oxigênio (DQO) como parâmetros de poluição no ribeirão Lavapés/Botucatu - SP. Eclet. Quím. vol.22 São Paulo 1997. Disponível em: http://dx.doi.org/10.1590/S0100-46701997000100005.

VALENTIM, M. A. A. Uso de leitos cultivados no tratamento de efluente de tanque séptico modificado. 1999. 137p. Dissertação (Mestrado em Engenharia Agrícola), Universidade Estadual de Campinas, Campinas.

Von SPERLING, M. Lodos ativados. 2.ed. Belo Horizonte: Departamento de Engenharia Sanitária e Ambiental - UFMG, 2002, 243p. (Princípios do tratamento biológico de águas residuárias, 4).

Von SPERLING, M. Introdução à qualidade das águas e ao tratamento de esgotos. Volume 1: Princípios do tratamento biológico de águas residuárias. 3.ed. Belo Horizonte: Departamento de Engenharia Sanitária e Ambiental, UFMG, 2005.

Von SPERLING, M. Estudos de modelagem da qualidade da água de rios. 1.ed. Belo Horizonte: Departamento de Engenharia Sanitária e Ambiental - UFMG, 2007, 243p. (Princípios do tratamento biológico de águas residuárias, 7).

VYMAZAL, J. Algae and element cycling in wetlands. Press/Lewis Publisher, Boca Raton, Flórida. 1995.

WETZEL, R.G. Limnology. 3. ed. Academic Press, San Diego. 1006p. 2001.

WOOD, A. Constructed wetlands in water pollution control: fundamentals to their understanding. Water Science and Technology, v.32, n.3, p.21-29, 1995. 
WOOD, R. B.; McATAMNEY, C. F. "Constructed wetlands for wastewater treatment: the use of laterite in the bed medium in phosphurus and heavy metal removal".Hidrobiologia, v. 340, p. 323-331, 1996.

YÁNEZ, F. Lagunes de estabilizacion. Ed.CEPIS, Lima , Peru, 379p., 1993.

ZACCAR, M. L.; GRANER, C. A. F.; LEOPOLDO, P.R. Determinação da demanda química de oxigênio (DQO) em águas e efluentes por método colorimétrico alternativo. Energ. Agric . Botucatu, vol.20, n 4, 2005, p. 69-82.

ZANELLA, L. Plantas ornamentais no pós-tratamento de efluentes sanitários: Wetlands - construídos utilizando brita e bambu como suporte. 2008. 189p. (Doutorado em Engenharia Civil, Arquitetura e Urbanismo) - Universidade Estadual de Campinas, Campinas. 